\title{
Stability of Perovskite Solar Cells: Degradation Mechanisms and Remedies
}

\author{
Sayantan Mazumdar ${ }^{1,2,3,4}$, Ying Zhao ${ }^{1,2,3,4 *}$ and Xiaodan Zhang 1,2,3,4* \\ ${ }^{1}$ Renewable Energy Conversion and Storage Center, Solar Energy Conversion Center, Institute of Photoelectronic Thin Film \\ Devices and Technology, Nankai University, Tianjin, China, ${ }^{2}$ Key Laboratory of Photoelectronic Thin Film Devices and Technology \\ of Tianjin, Tianjin, China, ${ }^{3}$ Engineering Research Center of Thin Film Photoelectronic Technology of Ministry of Education, Tianjin, \\ China, ${ }^{4}$ Collaborative Innovation Center of Chemical Science and Engineering (Tianjin), Tianjin, China
}

Inorganic-organic metal halide perovskite light harvester-based perovskite solar cells (PSCs) have come to the limelight of solar cell research due to their rapid growth in efficiency. At present, stability and reliability are challenging aspects concerning the Sibased or thin film-based commercial devices. Commercialization of perovskite solar cells remains elusive due to the lack of stability of these devices under real operational conditions, especially for longer duration use. A large number of researchers have been engaged in an ardent effort to improve the stability of perovskite solar cells. Understanding the degradation mechanisms has been the primary importance before exploring the remedies for degradation. In this review, a methodical understanding of various degradation mechanisms of perovskites and perovskite solar cells is presented followed by a discussion on different steps taken to overcome the stability issues. Recent insights on degradation mechanisms are discussed. Various approaches of stability enhancement are reviewed with an emphasis on reports that complied with the operational standard for practical application in a commercial solar module. The operational stability standard enacted by the International Electrotechnical Commission is especially discussed with reports that met the requirements or showed excellent results, which is the most important criterion to evaluate a device's actual prospect to be utilized for practical applications in commercial solar modules. An overall understanding of degradation pathways in perovskites and perovskite solar cells and steps taken to overcome those with references including state-of-the-art devices with promising operational stability can be gained from this review.

Keywords: perovskite, perovskite solar cell, perovskite degradation, perovskite defects, perovskite solar cell stability, additive engineering, encapsulation, International Electrotechnical Commission

\section{INTRODUCTION}

Organic-inorganic metal halide perovskite-based perovskite solar cells (PSCs) are at the epitome of attention to the solar cell research community due to their rapid growth in efficiency over a short period of time. It was first reported as a sensitized solar cell in 2009 with an efficiency of $3.81 \%$ (Kojima et al., 2009). Today, the efficiency of the laboratory-scale devices has exceeded 25\% (Kim et al., 2020a). The outstanding optoelectronic property of the perovskite facilitates the growth in efficiency (Yin et al., 2016a; Wu et al., 2019a; Jena et al., 2019). Rapid growth of efficiency bears a 
promise to replace commercial Si-based and thin film solar cells. The major obstacle in the way of commercialization is easy degradation of perovskites and PSCs (Boyd et al., 2019; Jena et al., 2019; Shi et al., 2020a; Wang et al., 2020a; Wang et al., 2020b; Yang et al., 2021). Both are vulnerable to external factors of ambient conditions. Various approaches are taken to overcome degradation, but commercial PSCs are still not realized. The rapid growth in efficiency of laboratory-scale devices always goes ahead of progress in stability in PSCs. Understanding the stability factors of perovskites and PSCs and studying the degradation mechanisms are extremely important (Wu et al., 2019a; Dunfield et al., 2020; Kumar et al., 2020). Knowledge of the degradation pathways has utmost importance in developing remedies for the factors responsible for degradation. In this review, almost all possible degradation mechanisms including the structural specialty of perovskite and PSCs are discussed in the first part. That will be helpful for the reader toward a systematic understanding of the degradation pathways in perovskites and PSCs. In the second part, various approaches to enhance the stability are discussed. We attempted to provide an updated and systematic overview on the remedies to overcome the stability issues in PSCs. As PSCs are considered for commercial applications, standard methods must be available to test the stability and reliability of the device. The International Electrotechnical Commission (IEC) sets up criteria that can be treated as a standard to trial the stability and reliability of PSCs. Those are exclusively discussed along with reports and attempts to achieve that (Zhu et al., 2016; Wang et al., 2020a). In all the sections discussing the strategies to improve the stability, the relevant reports with high operational stability (e.g., negligible loss of PV performance after several hundreds of hours' operation under harsh conditions such as $85^{\circ} \mathrm{C}, 85 \%$ relative humidity) are reviewed.

\section{STABILITY ISSUES IN LIGHT-HARVESTER PEROVSKITE AND PEROVSKITE SOLAR CELLS}

The long-time stability of perovskite and perovskite solar cells (PSCs) is very important for commercialization of PSCs (Wang et al., 2020b; Yang et al., 2021). But, various factors are responsible for the degradation of perovskite and other constituents of PSCs. In this section, the various stability issues are discussed. Studying various decomposition mechanisms is very important to adopt strategies to prevent decomposition. The degradation mechanisms can be understood by reconciling various experiments with theoretical calculations. The stability issues can be divided into: 1) Intrinsic stability-stability issues solely caused by the molecular and crystallographic structure of the perovskite (ideally $\mathrm{MAPbI}_{3}$ is discussed) and 2) Extrinsic stability-stability issues of mainly perovskite and the other components of PSCs upon external factors that are unavoidable in case of practical applications. One component of the PSCs can also cause degradation of the other component such as the decomposition of perovskite by a metallic

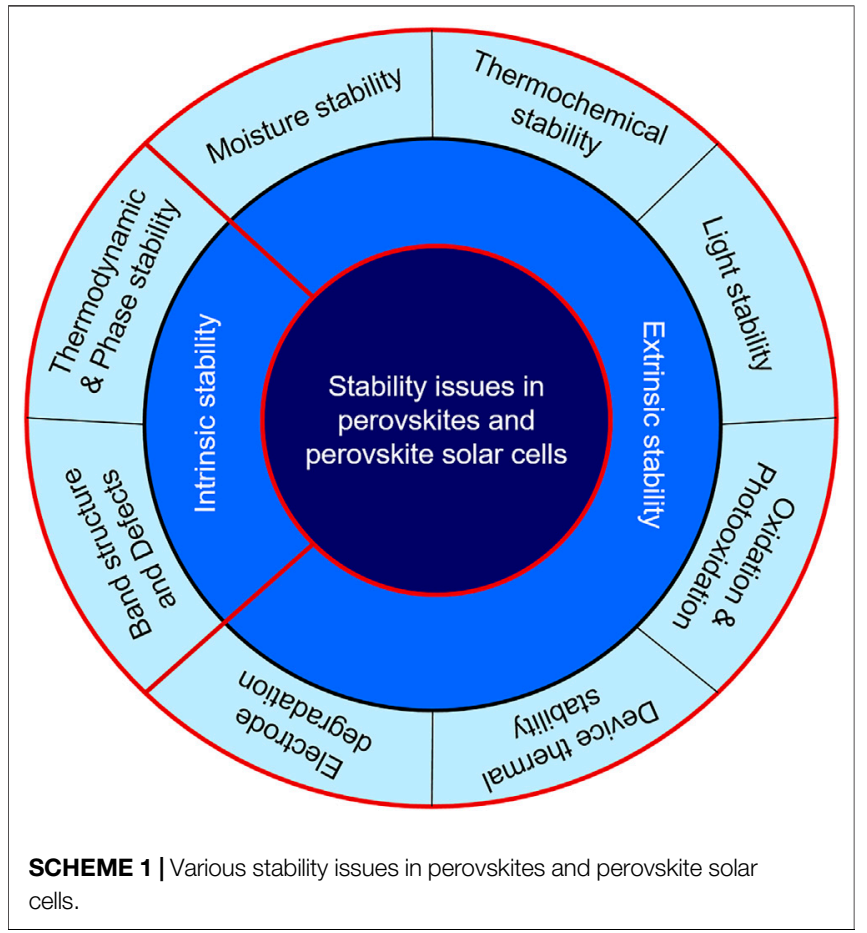

electrode. A classification of various stability issues is depicted in Scheme 1.

\section{Intrinsic Stability \\ Structural Stability}

Lev Perovski discovered and determined the crystallographic structure of the mineral $\mathrm{CaTiO}_{3}$ in 1839. That particular structure is called perovskite and it refers to a set of compounds with a certain $\mathrm{ABX}_{3}$ crystal structure. A refers to a larger monovalent cation, $\mathrm{B}$ is a smaller bivalent cation, and $\mathrm{X}$ is a monovalent anion that bonds with both $\mathrm{A}$ and $\mathrm{B}$. The stability of a certain perovskite structure can be predicted by the Goldschimdt tolerance factor $t$ that can be determined by the following simple equation ( $\mathrm{Li}$ et al., 2016a):

$$
t=\frac{\mathrm{R}_{\mathrm{A}}+\mathrm{R}_{\mathrm{X}}}{\sqrt{2}\left(\mathrm{R}_{\mathrm{X}}+\mathrm{R}_{\mathrm{B}}\right)}
$$

where $R_{A}, R_{B}$, and $R_{X}$ are the ionic radii of the $A, B$, and $X$ ions, respectively. Ideally, $t>1$ results in hexagonal or tetragonal structures. $1>t>0.9$ produces a cubic structure, $0.9>t>0.71$ gives an orthorhombic or rhombohedral structure, and $t<0.71$ does not produce a perovskite crystal structure (Figures 1A,B) (Yin et al., 2014; $\mathrm{Ma}$ et al., 2020a). The Goldschimdt tolerance factor $t$ is a zeroth-order approximation that facilitates ease of calculation in most of the cases, but anomaly has been found in approximately $26 \%$ of cases, as mentioned in some literatures (Bartel et al., 2019). Bartel et al proposed another tolerance factor that can be presented by the following equation (Bartel et al., 2019):

$$
\tau=\frac{R_{X}}{R_{B}}-n_{A}\left(n_{A}-\frac{R_{A} / R_{B}}{\ln \left(\frac{R_{A}}{R_{B}}\right)}\right)
$$



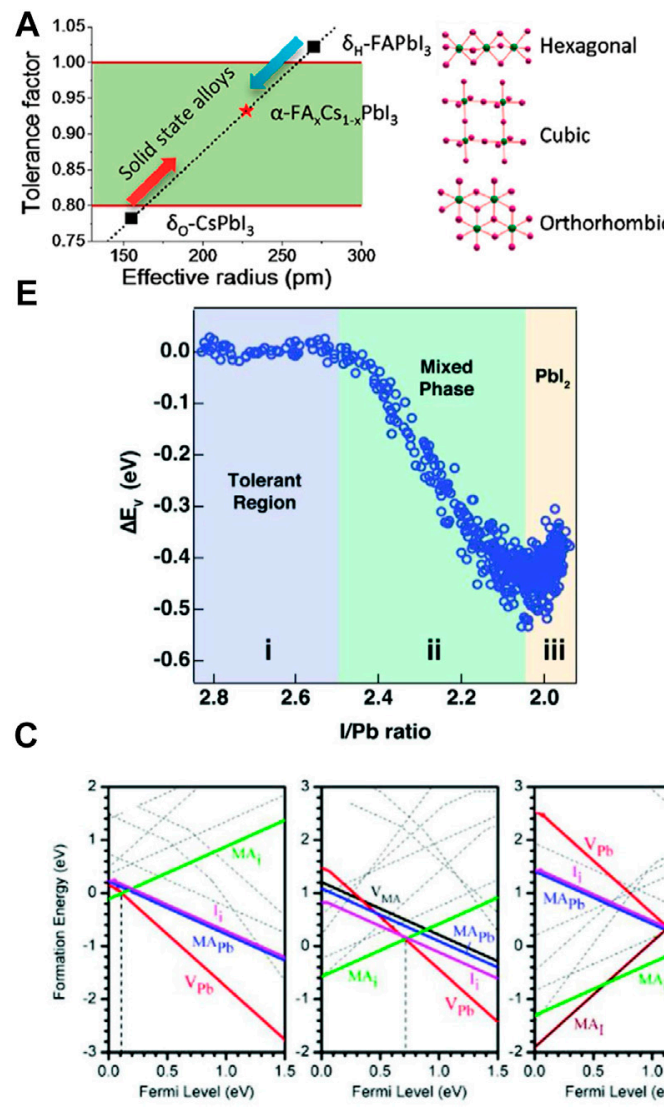

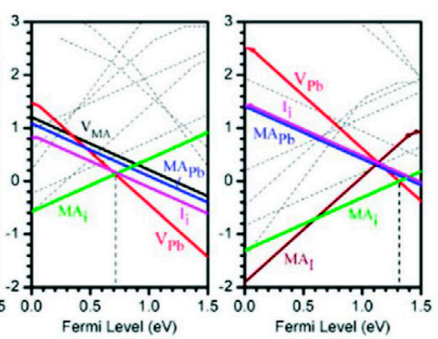

B

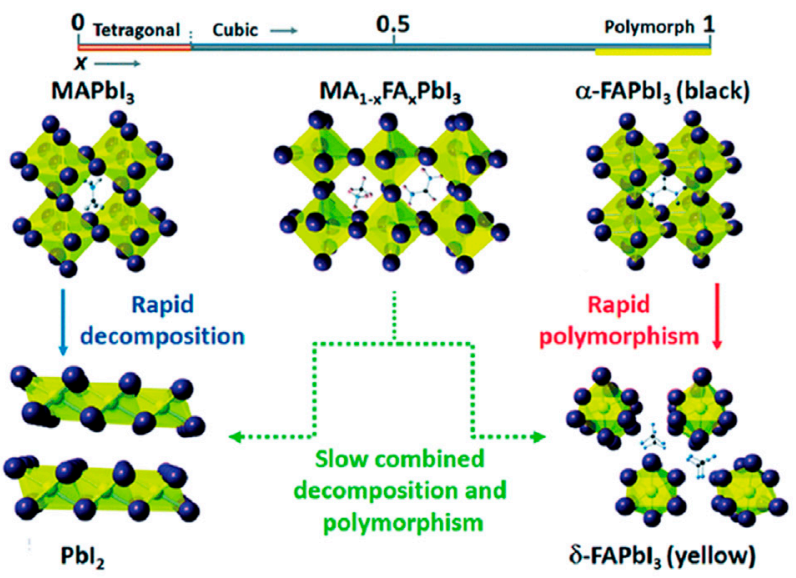

D

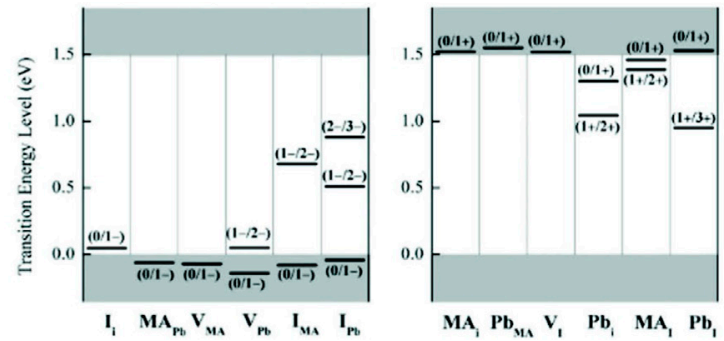

FIGURE 1 | Intrinsic stability of perovskites. (A) Representation of tolerance factor (t) with respect to effective ionic radius. Probability of various phases is also marked (Li et al., 2016a). Reproduced with permission. Copyright 2016, American Chemical Society. (B) Strategy of mixing of A-site species (Charles et al., 2017). Reproduced with permission. Copyright 2017, Royal Society of Chemistry. (C) and (D) represent defect tolerance of MAPbl 3 , as predicted by DFT calculations (Yin et al., 2014). Reproduced with permission. Copyright 2014, AIP Publishing. (C) depicts formation energies in three different scenarios, from left to right-I-rich/Pb-poor, neutral and Pb-rich/l-poor. (D) Transition energy levels for intrinsic acceptor (left) and donor (right) point defects. (E) Relation between valence band maximum and I/Pb ratio in $\mathrm{MAPbl}_{3}$ film, measured by XPS (Steirer et al., 2016). Reproduced with permission. Copyright 2016, American Chemical Society.

where $R_{A}, R_{B}$, and $R_{X}$ are the ionic radii of the respective species and $\mathrm{n}_{\mathrm{A}}$ is the oxidation state of the A cation. The possibility of a perovskite structure formation arises when $t<4.18$ and the lesser value increases the probability of the formation of perovskite. Equation 2 cannot predict the exact crystallographic structures such as Eq. 1, but it can predict the probability of perovskite formation more accurately than that of Eq. 1 and an anomaly has been observed in mere 8\% of cases (Poglitsch and Weber, 1987). So, it is highly prescribed to use both the equations on a certain species to accurately predict the probability of formation of a perovskite structure and the exact crystallographic structure (Dunfield et al., 2020).

In case of a monovalent $\mathrm{A}$ and divalent $\mathrm{B}$ moiety, they donate one and two electrons respectively to balance the tri-negative charges of the $\mathrm{X}$ anion. Thus, a bandgap is formed between the unoccupied B cation's $\mathrm{p}$ orbital and the occupied X anion's $\mathrm{p}$ orbital (Yin et al., 2014). The bandgap often lies in the visible range in case of metal inorganic-organic halide perovskites, thus making them suitable for solar photon harvesting. Those perovskites are the subject of this review.
Photon-harvesting properties of these species were first reported by Kojima et al. (2009). Various formulations are possible including the alloyed ones. In general, the A-site is represented by organic species methylammonium $\left(\mathrm{MA}^{+}\right)$, formamidinium $\left(\mathrm{FA}^{+}\right)$, or metallic $\mathrm{Cs}^{+}$. The $\mathrm{B}$-site is generally occupied by $\mathrm{Pb}^{2+}$ or $\mathrm{Sn}^{2+}$. The $\mathrm{X}$-site is composed by halide anions such as chloride $\left(\mathrm{Cl}^{-}\right)$, bromide $\left(\mathrm{Br}^{-}\right)$, or iodide ( $\mathrm{I}^{-}$) (Stoumpos et al., 2013a; Sutton et al., 2018). These different components must be tuned wisely to achieve suitable tolerance factors ( $t$ and $\tau$ ) while maximizing the solar photonharvesting ability of the resultant species (Dunfield et al., 2020).

The size of the respective moieties is very important. For example, if the ionic radius of $\mathrm{A}$ is too small, it cannot separate two B moieties effectively which leads to an edge-sharing octahedron while a much bigger A would lead to the formation of lower dimensional face-sharing octahedral structures, which may not be conducive to effective solar photon harvesting due to reasons such as wider band gap. A suitable A-site species should be able to perfectly separate two 
TABLE 1 | Crystallographic phase stability of various perovskites.

\begin{tabular}{|c|c|c|c|c|c|}
\hline Perovskite & $\begin{array}{l}\text { Phase: } \delta \\
\text { (yellow) }\end{array}$ & $\gamma($ low T) & $\beta(\operatorname{mid} T)$ & $\alpha$ (high T) & References \\
\hline $\mathrm{MAPbCl}_{3}(t=0.938)$ & & $<172.9 \mathrm{~K}$ (orthorhombic) & $\begin{array}{l}172.9-178.8 \mathrm{~K} \\
\text { (tetragonal) }\end{array}$ & $\begin{array}{l}>178.8 \mathrm{~K} \\
\text { (cubic) }\end{array}$ & $\begin{array}{l}\text { Poglitsch and Weber } \\
\text { (1987) }\end{array}$ \\
\hline $\mathrm{MAPbBr}_{3}(t=0.927)$ & $<144.5 \mathrm{~K}$ (orthorhombic) & 149.5-155.1 K (tetragonal) & $\begin{array}{l}155.1-236.9 \mathrm{~K} \\
\text { (tetragonal) }\end{array}$ & $\begin{array}{l}>236.9 \mathrm{~K} \\
\text { (cubic) }\end{array}$ & $\begin{array}{l}\text { Poglitsch and Weber } \\
\text { (1987) }\end{array}$ \\
\hline $\mathrm{MAPbI}_{3}(t=0.911)$ & & $<162.2 \mathrm{~K}$ (orthorhombic) & $\begin{array}{l}162.2-327.4 \mathrm{~K} \\
\text { (tetragonal) }\end{array}$ & $\begin{array}{l}>327.4 \mathrm{~K} \\
\text { (cubic) }\end{array}$ & $\begin{array}{l}\text { Poglitsch and Weber } \\
\text { (1987), Stoumpos } \\
\text { et al. (2013a) }\end{array}$ \\
\hline $\mathrm{FAPbl}_{3}(t=0.987)$ & $<438 \mathrm{~K}$ (hexagonal) & $<140 \mathrm{~K}$ (tetragonal) & $\begin{array}{l}140-285 \mathrm{~K} \\
\text { (tetragonal) }\end{array}$ & >285 K (cubic) & $\begin{array}{l}\text { Stoumpos et al. } \\
\text { (2013a) }\end{array}$ \\
\hline $\mathrm{CsPbl}_{3}(t=0.0 .807)$ & $<588$ K (orthorhombic) & & $>588$ K (cubic) & & $\begin{array}{l}\text { Stoumpos et al. } \\
\text { (2013a) }\end{array}$ \\
\hline $\mathrm{FAPbBr}_{3}(t=0.1 .008)$ & & $<125 \mathrm{~K}$ (orthorhombic) & $\begin{array}{l}150-250 \mathrm{~K} \\
\text { (tetragonal) }\end{array}$ & $>275 \mathrm{~K}$ (cubic) & Schueller et al. (2018) \\
\hline $\mathrm{CsPbBr}_{3}(t=0.815)$ & & <361 K (orthorhombic) & $\begin{array}{l}361-403 \mathrm{~K} \\
\text { (tetragonal) }\end{array}$ & >403 K (cubic) & $\begin{array}{l}\text { Stoumpos et al. } \\
\text { (2013b) }\end{array}$ \\
\hline $\mathrm{MASnl}_{3}(t=0.922)$ & & & $200 \mathrm{~K}$ (tetragonal) & $\begin{array}{l}293 \mathrm{~K} \\
\text { (tetragonal) }\end{array}$ & $\begin{array}{l}\text { Stoumpos et al. } \\
(2013 a)\end{array}$ \\
\hline $\mathrm{FASnl}_{3}(t=0.998)$ & & <125 K (orthorhombic) & $\begin{array}{l}150-225 \mathrm{~K} \\
\text { (tetragonal) }\end{array}$ & >250 K (cubic) & $\begin{array}{l}\text { Stoumpos et al. } \\
\text { (2013a) }\end{array}$ \\
\hline $\mathrm{Cs}_{2} \mathrm{Snl}_{6}$ & & & & 293 K (cubic) & $\begin{array}{l}\text { Stoumpos et al. } \\
\text { (2013a) }\end{array}$ \\
\hline $\mathrm{FA}_{x} \mathrm{MA}_{1-\mathrm{x}} \mathrm{Pbl}_{3}$ & Forms if $x>0.85$ & & $\begin{array}{l}<(257 \mathrm{~K}-283 \mathrm{~K}) \\
\text { (cubic) }\end{array}$ & $\begin{array}{l}298 \mathrm{~K}>\mathrm{T}> \\
523 \mathrm{~K} \\
\text { (tetragonal) }\end{array}$ & Weber et al. (2016) \\
\hline $\mathrm{FA}_{x} \mathrm{Cs}_{1-\mathrm{x}} \mathrm{Pbl}_{3}$ & $\begin{array}{l}<398 \mathrm{~K}, \mathrm{x}=0.85 ;<373 \mathrm{~K} \\
\mathrm{x}=0.07 ;<298 \mathrm{~K}, \mathrm{x}=0.55 \\
\text { (hexagonal) }\end{array}$ & $\begin{array}{l}>398 \mathrm{~K}, \mathrm{x}=0.85 ;>373 \mathrm{~K}, \mathrm{x}= \\
0.07, \text { with } \delta \text { phase; }>298 \mathrm{~K}, \mathrm{x}= \\
0.55, \text { with } \delta \text { phase (tetragonal) }\end{array}$ & & & Zhu et al. (2016) \\
\hline $\operatorname{MAPb}\left(\mathrm{I}_{1-x} \mathrm{Br}_{x}\right)_{3}$ & & $\begin{array}{l}298 \mathrm{~K} \text {, tetragonal for } x \leq 0.13 \\
\text { cubic for } x \geq 0.2\end{array}$ & & & Noh et al. (2013) \\
\hline $\mathrm{FAPb}\left(\mathrm{I}_{1-x} \mathrm{Br}_{x}\right)_{3}$ & $\begin{array}{l}\text { Amorphous phase for } x= \\
0.3 \text { to } 0.5\end{array}$ & $\begin{array}{l}298 K \text {, trigonal for } x<0.3 \text {, cubic } \\
\text { for } x>0.5\end{array}$ & & & Eperon et al. (2014) \\
\hline $\mathrm{FA}_{0.83} \mathrm{Cs}_{0.17} \mathrm{~Pb}\left(\mathrm{l}_{1-x} \mathrm{Br}_{\mathrm{x}}\right)_{3}$ & & & & $\begin{array}{l}298 \mathrm{~K} \text { for all } x \\
\text { (cubic) }\end{array}$ & $\begin{array}{l}\text { McMeekin et al. } \\
\text { (2016) }\end{array}$ \\
\hline$\left(\mathrm{FAPbI}_{3}\right)_{1-x}\left(\mathrm{MAPbBr}_{3}\right)_{x}$ & Forms if $x<0.15$ & & & $\begin{array}{l}298 \mathrm{~K}, \mathrm{x}=0.15 \\
\text { to } 0.3 \text { (trigonal) }\end{array}$ & Jeon et al. (2015) \\
\hline $\begin{array}{l}\mathrm{FA}_{0.75} \mathrm{MA}_{0.15} \mathrm{Cs}_{0.1} \mathrm{~Pb}\left(\mathrm{l}_{0.83} \mathrm{Br}_{0.17}\right)_{3} \\
(t=0.943)\end{array}$ & & & & 298 K (cubic) & Saliba et al. (2016a) \\
\hline $\begin{array}{l}\mathrm{FA}_{0.75} \mathrm{MA}_{0.15} \mathrm{Cs}_{0.05} \mathrm{Rb}_{0.05} \mathrm{~Pb}\left(\mathrm{l}_{0.83} \mathrm{Br}_{0.17}\right)_{3} \\
(t=0.958)\end{array}$ & & & & $\begin{array}{l}298 K \text { K (not } \\
\text { specified) }\end{array}$ & Saliba et al. (2016b) \\
\hline
\end{tabular}

B-site cations to achieve a symmetrical 3D cubic lattice (Quarti et al., 2016). However, the phases are changed with temperature and the properties of the perovskite are also changed as per. This subject is discussed in the following section.

\section{Thermodynamic Phase Stability}

Thermodynamic phase stability as determined by the tolerance factor $(t)$ for a particular species and also of the alloyed species are discussed in this section. As mentioned in 2.1.1, $1>t>0.9$ leads to an ideal cubic perovskite structure (Yin et al., 2014). But, when departed from that value, the $\mathrm{BX}_{6}$ octahedron starts to distort (Filip et al., 2014). For the ideal $\mathrm{MAPbI}_{3}$ molecule, $t=1.02$ and it forms a tetragonal perovskite structure at room temperature. The ionic radius of $\mathrm{FA}^{+}$is

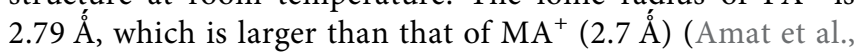
2014). The marginally oversized $\mathrm{FA}^{+}$leads to $t=1.04$ for $\mathrm{FAPbI}_{3}$ and it crystallizes into a non-perovskite hexagonal phase at room temperature and it must be converted into a cubic perovskite structure by annealing at more than $150^{\circ} \mathrm{C}$ temperature (Eperon et al., 2014; Lee et al., 2014a; Lee et al., 2015). On the other hand, $\mathrm{Cs}^{+}$has an ionic radius of $1.81 \AA$ that is much smaller than that of $\mathrm{FA}^{+}$and $\mathrm{MA}^{+}$. Thus, $t$ equals 0.81 in case of $\mathrm{CsPbI}_{3}$. So, it crystallizes to an orthorhombic phase at room temperature and annealing at $250^{\circ} \mathrm{C}$ is needed for the formation of a cubic phase (Amat et al., 2014; Chen et al., 2017). Despite having other beneficial properties, pure $\mathrm{FAPbI}_{3}$ and $\mathrm{CsPbI}_{3}$ often lag behind due to the thermodynamic phase stability issues, as annealing at a higher temperature leads to defects in perovskite films (Boyd et al., 2019; Ma et al., 2020a). The $t$ values presented in Table $\mathbf{1}$ are calculated as per the effective ionic radii

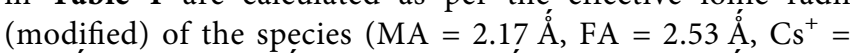

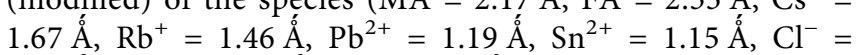

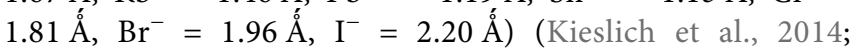
Nagabhushana et al., 2016). However, many reports have calculated $t$ as per the crystal ionic radii of the species. 
In most of the efficient devices, alloys are used. Understanding the thermodynamics of these alloys is very crucial and an alloyed species can be treated as a linear combination of two pristine perovskites (Saliba et al., 2016a). Thus, the suitability of an alloyed perovskite can be determined by: 1) To select proper $\mathrm{B}$-site and X-site moieties' ratios to obtain a suitable optical band gap and 2) to select a proper ratio of the A-site moieties to achieve a suitable tolerance factor (Saliba et al., 2016a; Saliba et al., 2016b; Ma et al., 2020a). The alloying at the A-site is governed by the Gibbs free energy of mixing $\left(\Delta G_{m i x}\right)$ at constant pressure and volume (Schelhas et al., 2019):

$$
\Delta G_{m i x}=\Delta H_{m i x}-T \Delta S_{m i x}
$$

where $\Delta G_{\text {mix }}$ is the enthalpy of mixing and $T \Delta S_{\text {mix }}$ is the entropy of mixing. $\Delta G_{m i x}<0$ is energetically favored to mix while $\Delta G_{m i x}>0$ may lead to phase segregation. These thermodynamic factors must be kept in mind while designing an alloy (Schelhas et al., 2019). Phase stability of various perovskites is listed in Table $\mathbf{1}$ with the respective temperatures.

\section{Electronic Band Structure and Stability Toward Defects}

Understanding the electronic band structure of the perovskite is crucial to determine the degree of defect tolerances. Bulk $\mathrm{MAPbI}_{3}$ is known as defect-tolerant, even the films are tolerant to defects/ vacancies compared with other light-harvesting semiconductor counterparts with respect to photovoltaic efficiency (Qi et al., 2020; Dhar et al., 2018). Density functional calculations are used to elucidate the effect of defect on $\mathrm{MAPbI}_{3}$ and are represented in (Figures 1C,D) (Yin et al., 2014). All the possible point defects are considered: vacancies $\left(V_{M A}, V_{P b}, V_{I}\right)$, interstitials $\left(M_{i}, P b_{i}, I_{i}\right)$, cation substitutions $\left(\mathrm{MA}_{\mathrm{Pb}}, \mathrm{Pb}_{\mathrm{MA}}\right)$, antisite substitutions $\left(\mathrm{MA}_{\mathrm{I}}\right.$, $\left.\mathrm{PB}_{\mathrm{I}}, \mathrm{I}_{\mathrm{MA}}, \mathrm{I}_{\mathrm{Pb}}\right)$. Different growth conditions of the perovskite significantly influence the defect formation energies and thus the concentration of defects. In the I-rich/Pb-poor case, the scenario is dominated by $\mathrm{V}_{\mathrm{Pb}}$ which leads the Fermi level to stay near the valence band. When the ratio of $\mathrm{Pb}$ is increased, the required energy to form a defect also increases and these cause $\mathrm{V}_{\mathrm{Pb}}$ and $\mathrm{MA}_{\mathrm{i}}$ to gain almost equal formation energies. So, the Fermi level resides near the midgap. A further increment of $\mathrm{Pb}$ with respect to I would cause the $\mathrm{Pb}$-rich/I-poor condition and $\mathrm{MA}_{\mathrm{i}}$ and $\mathrm{MA}_{\mathrm{I}}$ would determine the defect structure. The semiconductor would become n-type. Detrimental defects such as $\mathrm{I}_{\mathrm{MA}}, \mathrm{I}_{\mathrm{Pb}}, \mathrm{Pb}_{\mathrm{I}}$, and $\mathrm{Pb}_{\mathrm{i}}$ have very high formation energies. So, their formation is very rare. Hence, the formation of deep trap states is also rare. Defects with lower formation energies such as $\mathrm{V}_{\mathrm{MA}}, \mathrm{V}_{\mathrm{Pb}}, \mathrm{MA}_{\mathrm{i}}, \mathrm{I}_{\mathrm{i}}, \mathrm{Pb}_{\mathrm{MA}}$, and $\mathrm{MA}_{\mathrm{Pb}}$ may occur and form trap states $\sim 0.05 \mathrm{eV}$ in the bandgap. So, the formation of center of nonradiative recombination is less probable. This theoretical prediction of vacancy tolerance has also been experimentally verified (Steirer et al., 2016; Dhar et al., 2018).

The degree of defect tolerance in perovskites such as $\mathrm{MAPbI}_{3}$ is quite attractive compared with its other photovoltaic counterparts such as Si. A very low defect in Si can destroy its photovoltaic prospects. This should be credited to the exceptional band structure of $\mathrm{MAPbI}_{3}$ (Yin et al., 2014). This kind of study is extended to other related perovskites. A strong correlation between defect tolerance and structural stability $(t)$ has been observed (Figure 1E). Perovskites such as $\mathrm{MAPbBr}_{3}, \mathrm{CsPbBr}_{3}, \mathrm{CsSnI}_{3}, \mathrm{CsSnBr}_{3}$, and $\mathrm{CsSnCl}_{3}$ have $t=0.82$ to 0.85 where $t$ of $\mathrm{FAPbI}_{3}, \mathrm{FASnI}_{3}$, $\mathrm{MASnI}_{3}$, and $\mathrm{CsPbI}_{3}$ do not fall in this range (Xu et al., 2014; Steirer et al., 2016; Kang and Wang, 2017). So, favorable $t$ can be achieved by tuning the alloying at the A-site and it also can be an effective way to mitigate defects. It can be assumed that a perovskite with a high structural stability is also a defect-tolerant species. The defect-tolerances mentioned above are referred to bulk. The properties of the surfaces of these materials can be very different from the bulk. The chemical potentials can be highly varied due to the perturbation of the electronic structure on the surface than that of the bulk (Schulz et al., 2019). These defects are very crucial in extrinsic stability of perovskites because the surface is exposed first to the environment or to another interface. These are discussed in the following sections.

\section{Extrinsic Stability}

In the previous section, intrinsic stability factors of perovskites, particularly of $\mathrm{MAPbI}_{3}$ have been discussed. It is found that the perovskites have satisfactory intrinsic stability compared to their counterparts. However, the perovskites used in devices are subjected to external factors such as heat, moisture, light, and interface materials (Schulz et al., 2019). Perovskites and PSCs demonstrate instability to these factors. So, understanding degradation of perovskites and PSCs by these extrinsic factors is very crucial to take proper steps to mitigate these problems. In this section, important external factors affecting perovskites and PSCs are discussed.

\section{Interaction With Water Molecule and Pathways of Degradation}

Water alone as well as in the presence of oxygen is one of the most pervasive factors affecting perovskites. Water and any other polar solvent can affect perovskite due to their ability to form solvated phases. Polar solvents can be avoided by tuning the deposition strategies but, exposure to environmental moisture is unavoidable. Water molecule can hydrate the perovskite and form a monohydrate phase (Leguy et al., 2015; Askar et al., 2017).

$$
\mathrm{CH}_{3} \mathrm{NH}_{3} \mathrm{PbI}_{3}(\mathrm{~s})+\mathrm{H}_{2} \mathrm{O}(\mathrm{g}) \rightleftharpoons \mathrm{CH}_{3} \mathrm{NH}_{3} \mathrm{PbI}_{3} \cdot \mathrm{H}_{2} \mathrm{O}
$$

Dihydrate formation is also possible in films (Leguy et al., 2015; Askar et al., 2017).

$4\left[\mathrm{CH}_{3} \mathrm{NH}_{3} \mathrm{PbI}_{3} \cdot \mathrm{H}_{2} \mathrm{O}\right] \rightleftharpoons\left(\mathrm{CH}_{3} \mathrm{NH}_{3}\right) 4 \mathrm{PbI}_{6} \cdot 2 \mathrm{H}_{2} \mathrm{O}+3 \mathrm{PbI}_{2}+2 \mathrm{H}_{2} \mathrm{O}$

Both the reactions are reversible. So, if the hydrated products would be kept in an inert or moisture-free environment, it can be dehydrated to produce back perovskite with some minuscule irreversibility due to phase segregation. The hydration of the perovskite causes structural deformation of $\left(\mathrm{PbI}_{6}\right)^{4-}$ octahedra which converts the $3 \mathrm{D}$ network of the $\left(\mathrm{PbI}_{6}\right)^{4-}$ octahedra into a $1 \mathrm{D}$ chain of octahedra for the monohydrate and $0 \mathrm{D}$ for dihydrates. These weaken the chemical bonds between the A-site moiety and 

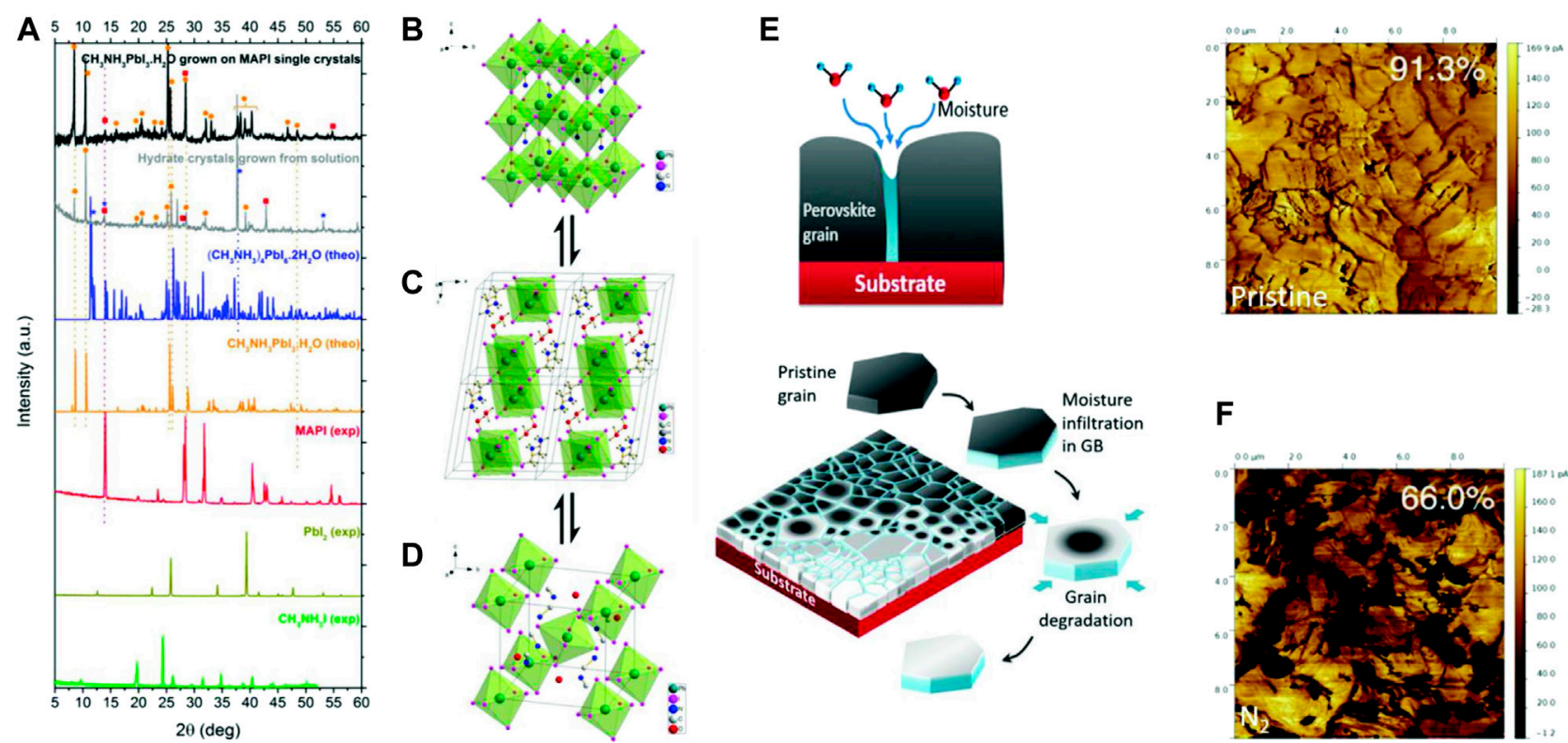

FIGURE 2 | (A-E) Effect of moisture on perovskite crystal structure. (A) XRD patterns of hydrated perovskite $\left(\mathrm{MAPbl}_{3}\right)$ with theoretical XRD patterns of MAI, Pbl ${ }_{2}$, $\mathrm{MAPbl}_{3}$, and hydrated-MAPbl $\mathrm{M}_{3}$ (B) Crystallographic structure of cubic phase $\mathrm{MAPbl}_{3}$, (C) monohydrate perovskite-MAPbl${ }_{3} . \mathrm{H}_{2} \mathrm{O}$, (D) dihydrate perovskite$(\mathrm{MA})_{4} \mathrm{Pbl}_{6} \cdot{ }_{2} \mathrm{H}_{2} \mathrm{O}$. (A-D) are reproduced with permission from (Leguy et al., 2015). Copyright 2015, American Chemical Society. (E) Schematic of moisture-induced degradation mechanism of the perovskite film which starts from grain boundaries (Wang et al., 2017a). Reproduced with permission. Copyright 2017, Royal Society of Chemistry. (F) Conductive atomic force microscopy (c-AFM) images of pristine $\mathrm{MAPbl}_{3}$ film (top) and MAPbl 3 film after heating at $85^{\circ} \mathrm{C}$ for $24 \mathrm{~h}$ under $\mathrm{N}_{2}$ (bottom) (Conings et al., 2015). Reproduced with permission. Copyright 2015, Wiley-VCH.

the $\left(\mathrm{PbI}_{6}\right)^{4-}$, thus making the perovskite more vulnerable to other extrinsic factors such as heat, electric bias. Once the perovskite will be saturated by the moisture, the hydration will become irreversible and it irreversibly will decompose to produce $\mathrm{CH}_{3} \mathrm{NH}_{3} \mathrm{I}$ and $\mathrm{PbI}_{2}$ (Christians et al., 2015). The effect of moisture is depicted in Figures 2A-E (Leguy et al., 2015; Wang et al., 2017a).

\section{Thermochemical Stability of Perovskite}

$\mathrm{MAPbI}_{3}$ can be degraded at $85^{\circ} \mathrm{C}$ temperature while being kept in an inert atmosphere, i.e. not under oxygen or moisture. A direct proof of this has been observed by comparing the nano-electrical properties of the pristine perovskite and after heating that (Figure 2F) (Conings et al., 2015). The proposed reversible and irreversible pathways of degradation of perovskite by heating are mentioned later (Conings et al., 2015; Juarez-Perez et al., 2016; Kim et al., 2017).

$$
\begin{gathered}
\mathrm{CH}_{3} \mathrm{NH}_{3} \mathrm{PbI}_{3}(\mathrm{~s}) \rightleftharpoons \mathrm{CH}_{3} \mathrm{NH}_{2}(\mathrm{~g})+\mathrm{HI}(\mathrm{g})+\mathrm{PbI}_{2}(\mathrm{~s}) \\
\mathrm{CH}_{3} \mathrm{NH}_{3} \mathrm{PbI}_{3}(\mathrm{~s}) \rightarrow \mathrm{CH}_{3} \mathrm{I}(\mathrm{g})+\mathrm{NH}_{3}(\mathrm{~g})+\mathrm{PbI}_{2}(\mathrm{~s})
\end{gathered}
$$

\section{Device Thermal Stability}

Reversible and irreversible decomposition of light harvester perovskites are discussed in the previous section. Other components are also needed in PSCs. Those also can be degraded upon heating at a marginally higher temperature. Spiro-OMeTAD is a widely used hole-transporting material in $n$-i-p PSCs. It can be crystallized at $100^{\circ} \mathrm{C}$, thus degrading the solar cell efficiency. Additives used with hole-transporting layers
(HTLs) can be evaporated at an even lower temperature of $85^{\circ} \mathrm{C}$ (Bailie et al., 2014; Jena et al., 2017). Oxides are attempted to replace organic charge-transporting layers, but electron-transporting oxides such as $\mathrm{ZnO}$ also can degrade the perovskite upon heating at $100^{\circ} \mathrm{C}$ (Liu et al., 2018a).

\section{Light Stability}

Stability of the light harvester material and the device are both crucial in determining the overall stability. Factors such as oxygen, moisture, and heating can be reduced or nullified by adopting certain strategies, but illumination by solar light is obvious. Many reports confirm that $\mathrm{MAPbI}_{3}$ does not degrade upon illumination even for several hundreds of hours, as confirmed by absorption spectra and other characterizations (Mei et al., 2014; Seo et al., 2018). The photoinduced changes in the perovskite even can be beneficial for PV properties, e.g., the ionic conductivity is increased by several orders of magnitude upon illumination of visible light (Kim et al., 2018). Lightinduced lattice expansion of the perovskite improves PEC of the device (Tsai et al., 2018). Stability of different constituents of the PSC under solar illumination is discussed in this section.

\section{Photostability of a Charge-Transporting Layer}

Organic charge-transporting layers such as fullerene-based materials are prone to degradation upon illumination (Abate et al., 2013; Mateker and McGehee, 2017). Though $\mathrm{TiO}_{2}$-based PSCs give many highest PV efficiencies, $\mathrm{TiO}_{2}$ layers are highly prone to degrade by UV light, even in inert condition. Rapid trapinduced recombination takes place on the titania surface due to 
photoinduced oxygen desorption (Dulub et al., 2007; Mazumdar et al., 2015a; Mazumdar and Bhattacharyya, 2015; Li et al., 2016b). This degradation induces several recombination pathways and results in rapid degradation of device performance. Many oxides such as $\mathrm{SnO}_{2}, \mathrm{ZnTiO}_{3}$, and $\mathrm{BaSnO}_{3}$ are UV-inert and do not obviously degrade upon long illumination. Hole transport oxides such as $\mathrm{NiO}_{\mathrm{x}}$ generally have wide bandgaps; hence, they are photostable. So, those may be suitable as stable charge-transporting layer. Many small organic molecule-based charge-transporting layers face degradation upon illumination due to UV (Wei et al., 2021).

\section{Light-Induced Ion Redistribution in Perovskites}

Light-induced redistribution of halide as well as metal ions is an important phenomenon observed in $\mathrm{MAPbI}_{3}$ and other perovskites. The photoluminescence of $\mathrm{MAPbI}_{3}$ film increases rapidly upon illumination over a short time (DeQuilettes et al., 2016). This is proven to be caused by the migration of $\mathrm{I}^{-}$species away from the light or the illuminated area of the film. The exact mechanism has not yet been reported, but evidence indicates that it is related to the slow diffusion of the ionic species along the perovskite layer, so it is also connected to the point defects such as halide vacancies. The increment in photoluminescence is more pronounced in the presence of oxygen and moisture due to an additional passivation effect of superoxide molecule (Brenes et al., 2017). Utilizing this phenomenon, $89 \%$ of internal photoluminescence quantum efficiency could be achieved with $32 \mathrm{~s}$ carrier lifetime and 19.2\% stable PCE in a $\mathrm{SnO}_{2}$-based n-i-p device. Hoke et al reported that $\mathrm{APb}\left(\mathrm{Br}_{\mathrm{y}} \mathrm{I}_{1-\mathrm{y}}\right)_{3}$ perovskites undergo phase segregation to $\mathrm{Br}^{-}$ and $\mathrm{I}^{-}$-rich perovskite phases upon illumination (Hoke et al., 2015). The phase segregation is reversible and the perovskite gains the initial structure and composition in dark. Increased photoluminescence of all these phase-segregated materials comes from lower energy states as carrier-trapping domains are created due to the presence of iodine-rich phases with smaller bandgaps. This indicates that the Br-rich and I-rich phases are effective in carrier trapping. This is labeled as "Hoke effect" and this phenomenon is only observed when the $\mathrm{Br}$ content is greater than $20 \%$ of the X-site. The Hoke effect is not observed when the $\mathrm{Br}$ content is less than $20 \%$. It causes a problem for PSCs in a tandem device where the desirable bandgap is generally $1.7-1.8 \mathrm{eV}$, so the perovskite contains $>20 \% \mathrm{Br}$ and the PSCs suffer structural instability. Light-induced cation segregation is also observed in alloyed perovskites (Domanski et al., 2017). In a triple alloyed perovskite at the A-site $\left(\mathrm{FA}_{0.79} \mathrm{MA}_{0.16} \mathrm{Cs}_{0.05}\right)_{0.97} \mathrm{~Pb}\left(\mathrm{I}_{0.84} \mathrm{Br}_{0.16}\right)_{2.97}$ is studied by time-of-flight secondary ion mass spectrometry (TOFSIMS) (Christians et al., 2018). Upon illumination, it is observed that the halide and lead distribution remain unchanged through the depth of the device, but all the A-site cations are redistributed. The redistribution of $\mathrm{Cs}^{+}$is more than that of $\mathrm{MA}^{+}$and $\mathrm{FA}^{+}$. This phenomenon is only observed with $\mathrm{TiO}_{2}$ electron-transporting layers (ETLs), but not observed with other ETLs such as $\mathrm{SnO}_{2}$.

\section{Photochemical Degradation}

As a semiconductor, $\mathrm{MAPbI}_{3}$ forms an excited state upon illumination. In the excited state, the ionic mobility increases due to iodide vacancies which is generated by oxidation of iodide atoms by photogenerated holes. Transformation to iodine from iodide causes reduction of ionic/atomic size and causes it to leave the lattice and form an interstitial vacancy (Mosconi et al., 2016; Tang et al., 2016; Cappel et al., 2017; Kim et al., 2018).

$$
\mathrm{I}^{\mathrm{x}}{ }_{\mathrm{I}}+\mathrm{h}^{+} \rightarrow \mathrm{I}^{\mathrm{x}}{ }_{\mathrm{i}}+\mathrm{V}_{\mathrm{I}}^{+}
$$

This process leads to irreversible decomposition products such as lead, iodine, and MAI. The iodine can be removed by sublimation, and thus increases the rate of this reaction. This process is depicted in Figures 3A,B. The presence of metallic lead has been detected by XPS even after illumination of short time (Tang et al., 2016; Cappel et al., 2017). Evidence of photoinduced degradation due to operating voltage has also been reported. High-performance PSCs with n-i-p structure are generally stable at the maximum power point. However, some devices demonstrate slow decomposition at both open circuit voltage and maximum power point (Wang et al., 2017b).

\section{Oxidation and Photooxidation of Charge-Transporting Layers and Perovskites}

Several oxides $\mathrm{TiO}_{2}, \mathrm{SnO}_{2}$, and $\mathrm{NiO}_{\mathrm{x}}$ are used in PSCs as chargetransporting layers. $\mathrm{TiO}_{2}$ is prone to oxidation in the presence of UV light and oxygen. It can catalyze oxidative decomposition of other materials in contact with them. These can limit the stability of the device. However, replacing $\mathrm{TiO}_{2}$ by $\mathrm{SnO}_{2}$ can prevent this (Christians et al., 2018). Organic molecules used as chargetransporting layers such as fullerene-based molecules are prone to photooxidation. The degradation of a chargetransporting layer is detrimental to the carrier mobility, thus affecting the long-term efficiency of PSCs. HTLs such as SpiroOMeTAD require some degree of oxidation to generate free holes in the HOMO, which enhances the p-type conductivity and facilitates the hole transportation to the metal electrode (Heo et al., 2013; Christians et al., 2015; Zhu et al., 2018a).

Metal halide perovskites are highly prone to photooxidation. Oxygen starts diffusing perovskite crystals almost instantaneously upon illumination and the decomposition is completed within an hour (Aristidou et al., 2017). Oxygen absorbs and diffuses through iodide vacancies in this process. Iodide vacancies preexist and increase rapidly upon illumination and thus facilitate the diffusion of oxygen (Abdelmageed et al., 2016; Wang et al., 2017b; Dhar et al., 2017).

\section{Interaction With Electrodes and Degradation at Interfaces}

Reaction of various species of the perovskite with the metal electrode is very crucial because this is the one way of decomposition which cannot be prevented by encapsulation. Certain metals are able to directly make redox couple with the perovskite itself or react with $\mathrm{PbI}_{2}$ (Zhao et al., 2016). Au does not react with the perovskite but it reacts with reactive polyiodide melts formed by perovskite decomposition (Abate et al., 2013). Most of the metals react with the perovskite decomposition products. Three of the reaction pathways of the metal electrode are mentioned below and depicted in Figure 3C. These are found by the TOF-SIMS studies. The corresponding 


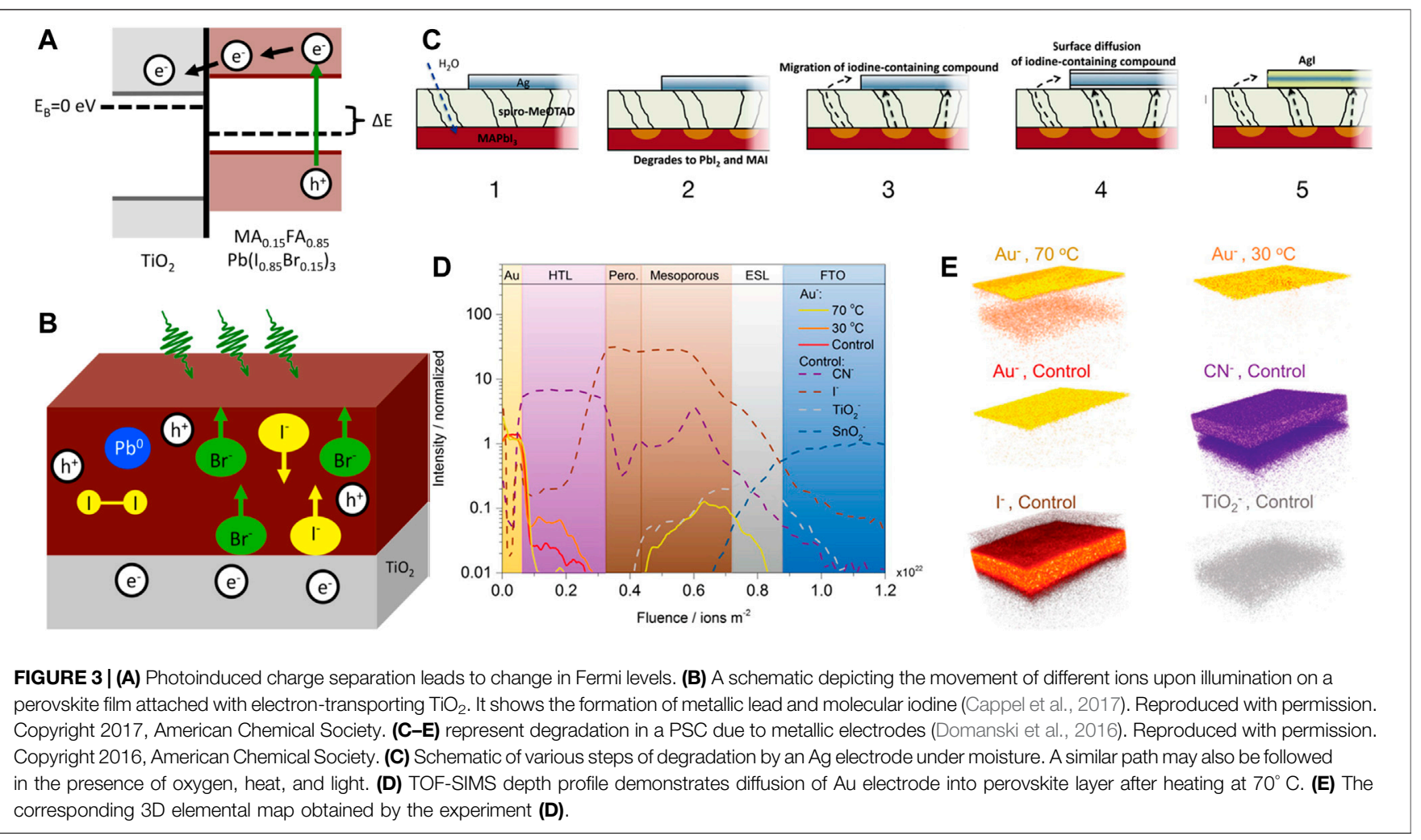

depth profiles and the simulated elemental maps are presented in Figures 3D,E respectively (Kato et al., 2015; Domanski et al., 2016; Zhao et al., 2016).

1) X-site species are formed by perovskite degradation; those diffuse to metal electrode. This reaction leads to corrosion of the metal electrode and also enhances decomposition of perovskite.

2) Metal electrode forms a redox couple with $\mathrm{Pb}^{2+}$. The perovskite decomposes quickly forming metallic $\mathrm{Pb}$.

3) Metal from electrode may diffuse to the perovskite and react to form metal halides, thus decomposing the perovskite and degrading the metal electrode.

\section{STRATEGIES TO RESIST DEGRADATION AND TO IMPROVE STABILITY}

In the previous section various degradation mechanisms of perovskite and PSCs are discussed. Various strategies have been adopted to mitigate the cause of degradation and to improve the stability while keeping up the efficiency. Studying the increment of efficiency needs much patience than that of research solely focused on increasing the efficiency because the stability must be studied over long time. Some strategies are targeting one particular degradation path while multipronged approaches are also reported where one particular strategy can help in resisting multiple ways of degradations. The stabilityenhancing steps must be decided after deliberation so that the strategy to resist one type of degradation should not introduce new ways of other degradations. The authors propose different ways of classification of these strategies (Wu et al., 2019a; Boyd et al., 2019; Wang et al., 2020a; Kumar et al., 2020; Yang et al., 2021). Our approach is summarized in Scheme 2.

\section{Stability Induced by Charge-Transporting Layer}

Charge-transporting materials play a key role in determining the efficiency and stability of PSCs. The electronic band structure of the charge-transporting layer is very important in this regard. The energy levels (valence band maximum-conduction band minimum in case of semiconductor species such as metal oxides, HOMO-LUMO in case of molecular species) should be well matched to facilitate the transfer of photogenerated charge followed by efficient transportation of charges to the respective electrodes. Well-matched energy levels can facilitate charge separation, and thus can reduce the probability of recombination. These can help in improving the short-circuit current and the fill factor. Mobility of charge (electron or hole) is also an important factor in determining the competence of a charge-transporting material. High mobility of the chargetransporting material helps in faster charge transport. If two charge-transporting materials with different mobility are at the same carrier concentration, the material with higher mobility will have higher conductivity. Efficient transportation leads to lesser energy/carrier loss and that leads to higher open circuit voltage. The charge-transporting material should be stable at the interface 


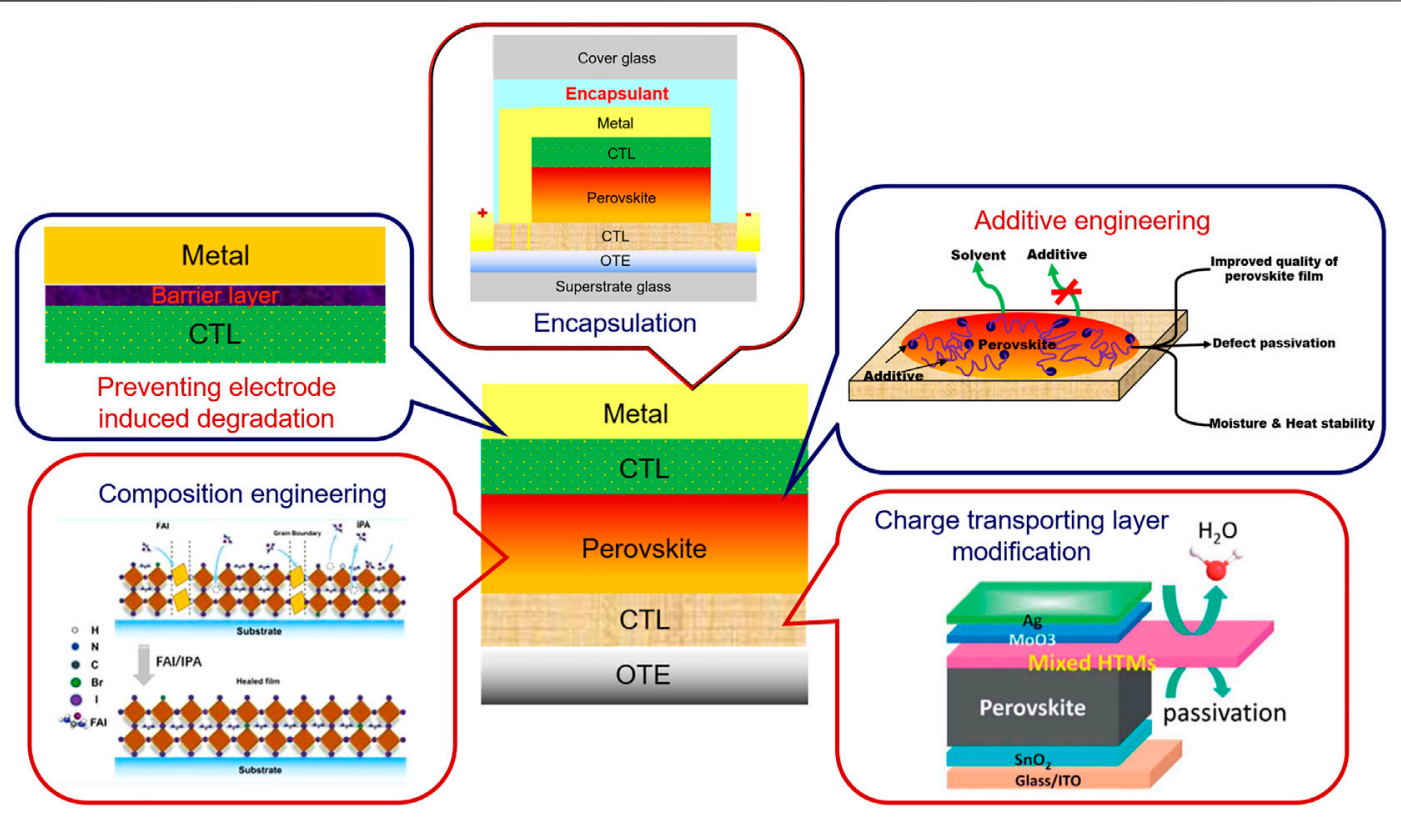

SCHEME 2 |Various remedies to prevent degradation and enhance the efficiency and stability of perovskite solar cells. Various figures are taken from the following references- Ji et al. (2020) (Charge transporting layer modification), Lin et al. (2018) (Composition engineering), and Wang et al. (2019f) (Additive engineering). Reproduced with permissions. Copyrights- 2020, Royal Society of Chemistry; 2018 American Chemical Society; 2019 Wiley-VCH respectively.

of the perovskite. Compact charge-transporting layers further prevent external moisture or oxygen to reach the perovskite. Diffusion engineering of the charge-transporting layer can highly boost the stability as the outward diffusion of iodine from the perovskite layer and inward diffusion of external elements can be controlled simultaneously (Bera et al., 2015; Hou et al., 2015; Wang et al., 2020c).

\section{Electron-Transporting Layers}

Various metal oxides (binary and ternary) have been utilized as the electron-transporting layer of PSCs. The conduction and valence band of $\mathrm{MAPbI}_{3}$ lie in -3.9 and $-5.4 \mathrm{eV}$, respectively. The ETL material's conduction band edge must be equal to or lower than that of $-3.9 \mathrm{eV}$ to be able to receive photogenerated electron from the perovskite, while the valence band edge should lie well below $-5.4 \mathrm{eV}$ to block any photogenerated holes from the perovskite (Figure 4) (Wang et al., 2018a; Mazumdar et al., 2019; Wang et al., 2020c).

The development of PSCs was started as a sensitized solar cell and the mesoporous $\mathrm{TiO}_{2}$ layer was used as the ETL (Kojima et al., 2009) which was the best candidate for a sensitized solar cell (Mazumdar and Bhattacharyya, 2012; Mazumdar and Bhattacharyya, 2013; Mazumdar et al., 2015b). Several nanostructures of $\mathrm{TiO}_{2}$ have been employed as ETL of PSCs (Qiu et al., 2013; Yella et al., 2014; Zheng et al., 2016; Wang et al., 2020c). Some of them are proven to be advantageous like branches of a nanodendrite structure can shorten the electron diffusion length and thus enhance the light trapping. Snaith et al replace PSCs with a mesoporous $\mathrm{TiO}_{2}$ layer by a much thinner layer, effectively a planar device (Leijtens et al., 2014). The efficiency boosts to $8.6 \%$ from $2.6 \%$ due to reduced recombination pathways between ETL and HTL. However, the biggest problem with $\mathrm{TiO}_{2}$ is that it can be degraded by the UV part of the solar radiation which is discussed in Photostability of Charge Transporting Layer.

$\mathrm{ZnO}$ is proposed as an excellent candidate as ETL due to its high electron mobility compared to $\mathrm{TiO}_{2}$ (Zuo et al., 2015; You et al., 2016). However, ZnO ETL faces several issues such as improper wetting by the perovskite, degradation of the perovskite (Son et al., 2014). The degradation of perovskite occurs at the $\mathrm{ZnO}$ interface due to the presence of radicals such as the hydroxyl (-OH) group (Dkhissi et al., 2016). Two approaches have been taken to solve this problem: 1) To introduce an additional layer with a proper energy alignment between $\mathrm{ZnO}$ and the perovskite. A $\mathrm{ZnO}-\mathrm{CdS}$ core-shell structure is used as the ETL (Liu et al., 2015). The CdS lies between $\mathrm{ZnO}$ and the perovskite. Proper band alignment of CdS allows photogenerated electron flow from the perovskite to $\mathrm{ZnO}$, while it debars the perovskite to come in direct contact with $\mathrm{ZnO}$ which may cause degradation of perovskite. This device is proven to be stable up to at least 60 days. 2) Physical deposition of $\mathrm{ZnO}$ by high vacuum methods such as sputtering and pulse laser deposition (PLD) is proven to be highly effective to achieve efficient and stable devices (Zhao et al., 2019; Mazumdar et al., 2020). The surface of physically deposited $\mathrm{ZnO}$ films is devoid of chemical moieties such as hydroxyl group which causes degradation of perovskite. So those can assure high efficiency and good stability.

$\mathrm{SnO}_{2}$ is proposed to be a suitable alternative to $\mathrm{TiO}_{2}$ (Yang et al., 2018a; Christians et al., 2018; Wang et al., 2019a; Wang et al., 2019b; Wang et al., 2019c; Wang et al., 2020c). Initial efficiencies were not satisfactory due to high rate of recombination at the interface. The problem was attempted to 


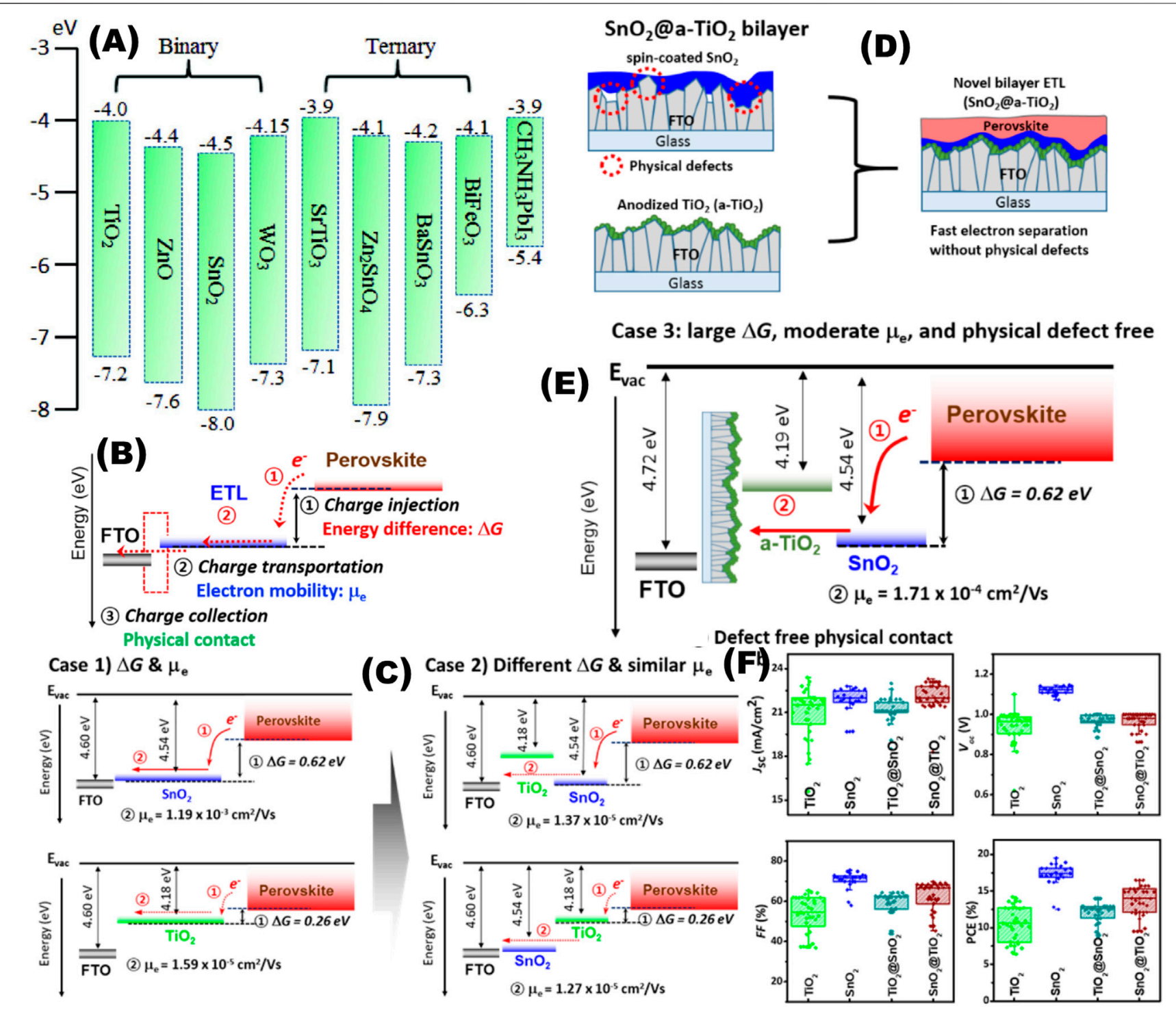

FIGURE 4 | Electron-transporting layer for perovskite solar cells. (A) Energy levels of various inorganic metal oxide ETLs are depicted w.r.t perovskite (Wang et al., 2018a). Reproduced with permission. Copyright 2018, Wiley- $\mathrm{VCH}$. (B-F) Bilayer of $\mathrm{ETL}\left(\mathrm{TiO}_{2}\right.$ and $\mathrm{SnO}_{2}$ ) optimized as per free energy difference $(\Delta G)$ between the $\mathrm{ETL}$ and the perovskite and the electron mobility $\left(\mu_{e}\right)$ of the ETL. (B) Schematic illustration of electron transportation. Electron extraction occurs from the perovskite to the FTO

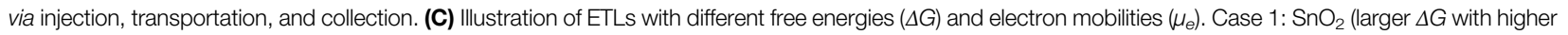
$\mu_{\mathrm{e}}$ ) and $\mathrm{TiO}_{2}$ (smaller $\Delta \mathrm{G}$ with lower $\mu_{\mathrm{e}}$ ). Case 2: $\mathrm{SnO}_{2} @ \mathrm{TiO}_{2}$ (larger $\Delta G$ with similar $\mu_{\mathrm{e}}$ ) and $\mathrm{TiO}_{2} @ \mathrm{SnO}_{2}$ (smaller $\Delta G$ with similar $\mu_{\mathrm{e}}$ ). (D) Schematic illustration of the bilayered $\mathrm{SnO}_{2} @ \mathrm{TiO}_{2} \mathrm{ETL}$. The dotted red circles indicate examples of physical defects on the $\mathrm{SnO}_{2} \mathrm{ETL}$. (E) Illustration of bilayered ETLs with large $\Delta G$ and moderate $\mu_{e}$. (F) Histograms of devices fabricated by $\mathrm{TiO}_{2}, \mathrm{SnO}_{2}, \mathrm{TiO}_{2} @ \mathrm{SnO}_{2}$, and $\mathrm{SnO}_{2} @ \mathrm{TiO}_{2} \mathrm{ETLs}$ (Song et al., 2017). Reproduced with permission. Copyright 2017, American Chemical Society.

be solved by surface treatment (Huang et al., 2018). Poor crystallinity of $\mathrm{SnO}_{2}$ is another obstacle to achieve good efficiencies. Tuning the synthesis of $\mathrm{SnO}_{2}$ nanostructures leads to crystalline $\mathrm{SnO}_{2}$ which produces efficient and stable PSCs ( $\mathrm{Zhu}$ et al., 2016; Wang et al., 2019a). $\mathrm{WO}_{3}$ is another candidate with good potential and various efforts are being engaged to acquire high efficiency (Huang et al., 2010; Mahmood et al., 2015; Wang et al., 2019a).
Ternary metal oxides such as $\mathrm{SrTiO}_{3}, \mathrm{BaSnO}_{3}$, and $\mathrm{Zn}_{2} \mathrm{SnO}_{4}$ are also investigated as ETLs. $\mathrm{SrTiO}_{3}$ can be a suitable candidate with high electron mobility $\left(5-8 \mathrm{~cm}^{2} \mathrm{~V}^{-1} \mathrm{~s}^{-1}\right)$ (Shin et al., 2017; Neophytou et al., 2019). Its conduction band edge is slightly higher than that of $\mathrm{TiO}_{2}$, so it can produce a higher open circuit voltage. The charge recombination on the surface can be suppressed due to its higher dielectric constant (Wang et al., 2015). For the same reason, quaternary IGZO has been tried as 
TABLE 2 | Effect of electron-transporting layers on efficiency and stability of PSCs.

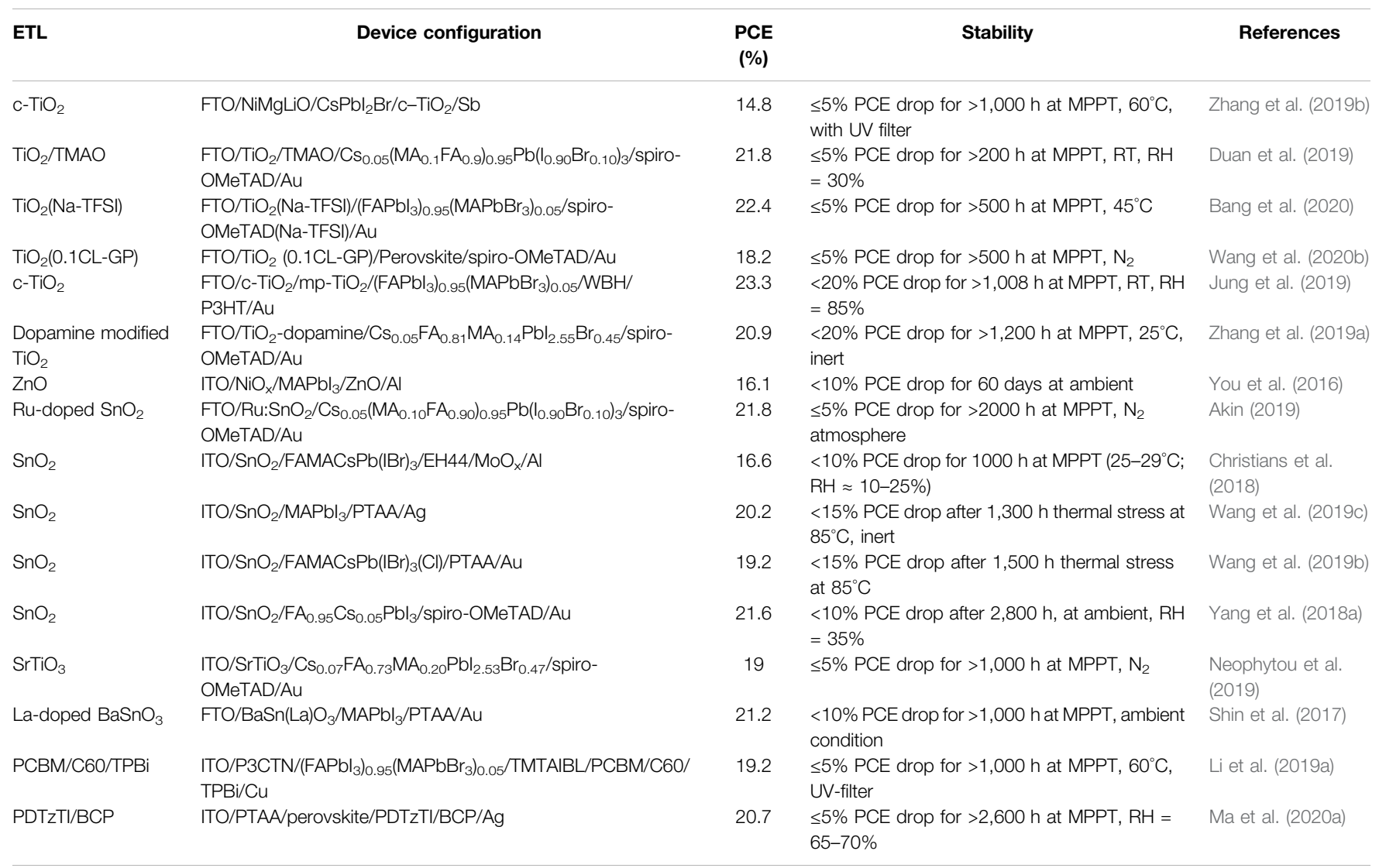

ETL (Rao et al., 2019). However, perovskite crystallization on the surface of these oxides and surface area are issues of concern.

Organic ETLs are also widely reported in the PSCs literature. Those can be subjected to low-temperature processing and can easily be used in flexible devices. Those can be divided into two types, namely fullerene-based and non-fullerene ETLs. Organic ETLs form compact layer for efficient electron extraction. Organic ETLs can diffuse to grain boundaries of perovskite film and can passivate the charge traps, thus stabilizing the device. The high cost or the difficulty in synthesis of some organic ETLs are major hurdles for commercialization (Chen et al., 2015; Yin et al., 2016a).

Composition or interface engineering is proven to be very useful to overcome deficiencies of a particular ETL with good potential (Li et al., 2019a; Ma et al., 2020a). Another layer of a suitable material is used in several reports to increase the charge transport across the ETL (Ren et al., 2021). A layer of graphene is introduced with $\mathrm{SrTiO}_{3}$ to significantly increase the current conduction and the stability of the device (Wang et al., 2015). In composite layers, understanding and controlling the interfacial charge transfer at the heterojunction has the paramount importance. Song et al identified that two factors namely the free energy difference $(\Delta G)$ between the ETL and the perovskite and the electron mobility $(\mu e)$ of the ETL are the key factors in regulating the charge transfer and transportation (Song et al., 2017). Two metal oxides, spin-coated $\mathrm{SnO}_{2}$ and $\mathrm{TiO}_{2}$ (nanoparticle and anodized, two types) are chosen. Their combinations are tuned as per the understanding of $\Delta G$ and $\mu$. The best combination of these two ETLs yields in PCE of $21.1 \%$, in a planar device (Figure 4).

Our approach is gradient energy alignment in case of ETL (Wang et al., 2015). Two oxides $\mathrm{In}_{2} \mathrm{O}_{3}$ and $\mathrm{SnO}_{2}$ are used as the ETL one upon another layer (Wang et al., 2020d). It was carried out by a low temperature process. The presence of $\operatorname{In}_{2} \mathrm{O}_{3}$ assists in the formation of a low-trap-density perovskite film. The conduction band of $\operatorname{In}_{2} \mathrm{O}_{3}$ is shallower than that of the ITO electrode. It highly enhances the charge transfer from the perovskite to ETL and minimizes the loss of $\mathrm{V}_{\mathrm{OC}}$. A planar PSC achieves a power conversion efficiency of $23.24 \%$ (a certified efficiency of $22.54 \%$ ) which is higher than that of the control device with only $\mathrm{SnO}_{2}$ (21.42\%). This device retained $97.5 \%$ of its efficiency over 80 days, in a $\mathrm{N}_{2}$ atmosphere without encapsulation. Several methods have been attempted in interface engineering. Doping of oxides by a suitable metal is a widely used strategy (Kim et al., 2015; Akin, 2019; Bang et al., 2020; Wang et al., 2021). Mobility or conductivity of the oxide can be greatly enhanced upon doping by suitable moiety and it also can enhance the stability by suppressing the carrier recombination in ETL. A few examples are available where an organic layer is used along with the oxide ETL (Kim et al., 2015; Zhang et al., 2019a; Duan et al., 2019; Wang et al., 2020b). Both the species can enhance the electron transportation in synergy 

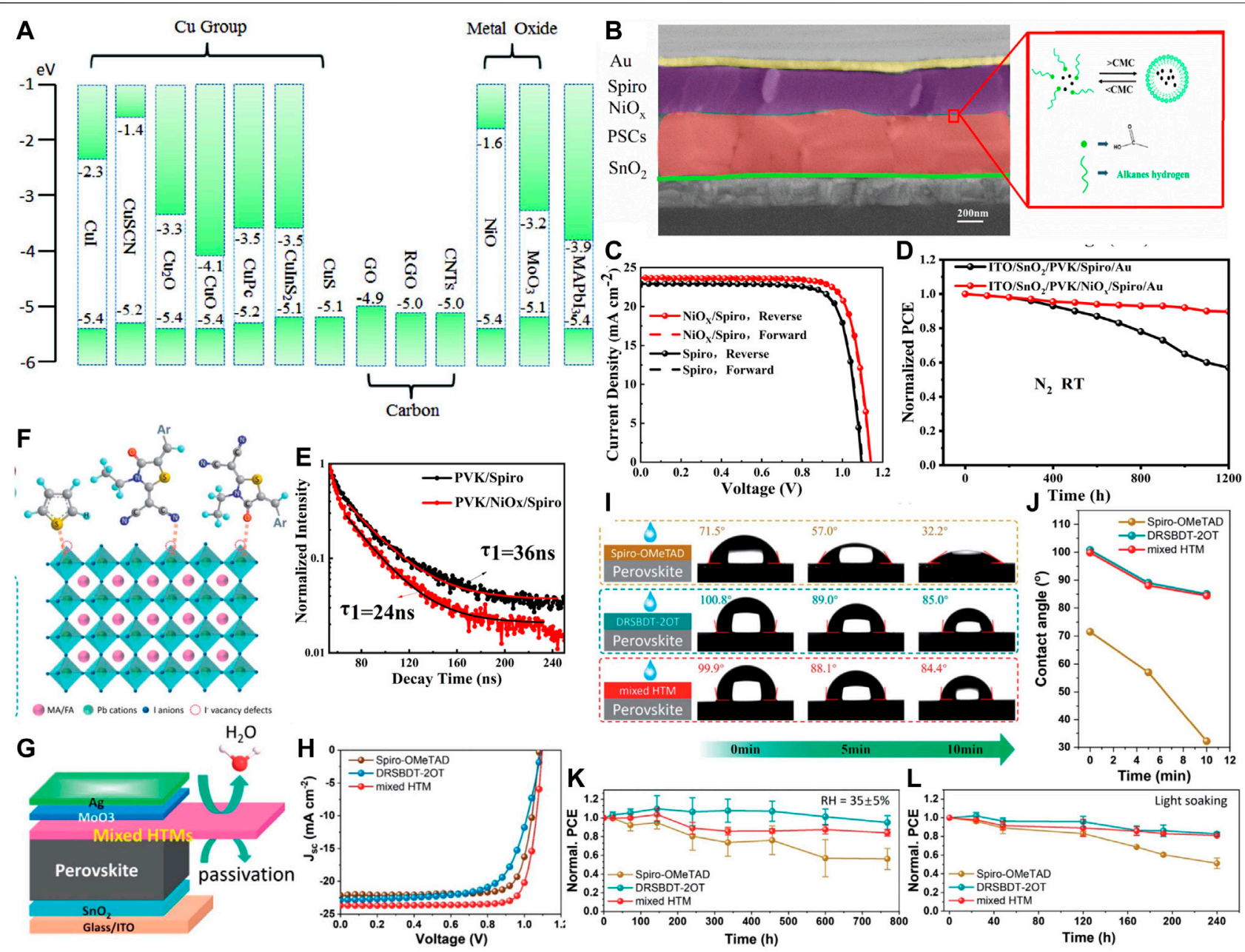

J Time (h)

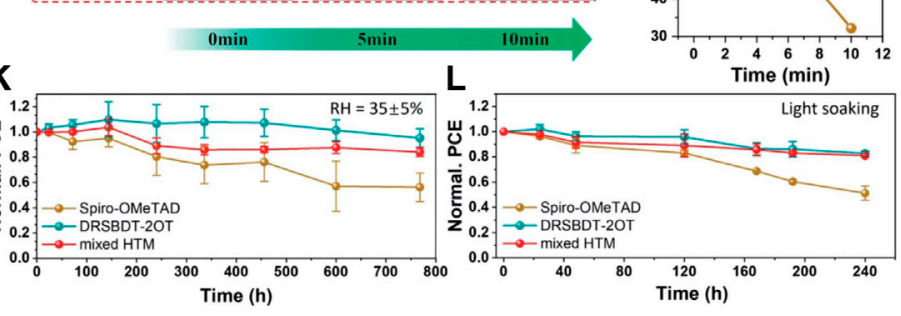

FIGURE 5 | Hole-transporting layers for perovskite solar cells. (A) Energy level alignments of various inorganic HTLs w.r.t. perovskite energy alignments (Wang et al., 2018a). Reproduced with permission. Copyright 2018, Wiley-VCH. (B) Modification of NiO HTL. (C) PV performance and (D) stability of the respective devices. (E) Time-resolved PL of spiro and the spiro/NiO films with perovskite (Li et al., 2020a). Reproduced with permission. Copyright 2020, American Chemical Society. DRSBDT-2OT molecules are used to modify Spiro HTL. (F) Interaction of DRSBDT-2OT with perovskite. (G) Schematic of the device showing the ability of the molecule in simultaneous passivation of perovskite defects and repulsion of moisture from ambience. (H) PV performance of the device. (I) and (J) water droplet contact angle measurement results (K) and (L) stability of the devices (Ji et al., 2020). Reproduced with permission. Copyright 2020, Royal Society of Chemistry.

where one of them can be effective in blocking holes. Understanding the diffusion of ions from perovskite to the ETL is very important in designing novel ETLs which can provide stability to the PSCs.

The intelligent designing strategy of the ETL has also been proven to be effective. A sparse array of $\mathrm{TiO}_{2}$ nanorods are nanopatterned and the ETL film is passivated by a ultrathin layer of PMMA:PCBM. The $\mathrm{TiO}_{2}$ nanorods remain incompletely covered and the resistance would be low in the uncovered regions. This device achieved $23.17 \%$ PCE and encapsulated devices retain $\sim 91.7 \%$ of the PCE after $1,000 \mathrm{~h}$ of damp-heat test (Peng et al., 2021). A few examples of ETLs with good PV performance and excellent stability are listed in Table 2 along with the respective stability test conditions.

\section{Hole-Transporting Layers}

A HTL's valence band maximum must lie between the bandgaps of the light harvester perovskite to receive photogenerated holes. Additionally, the conduction band should be high enough to stop any electron (Wang et al., 2018a). Various inorganic materials are reported such as $\mathrm{NiOx}, \mathrm{C}$-based structures such as graphene oxide (GO), reduced graphene oxide (RGO), C-nanostructures, and various $\mathrm{Cu}$-based materials (Figure 5A).

$\mathrm{NiO}$ or $\mathrm{NiO}_{\mathrm{x}}$ are highly reported as HTL in both $\mathrm{n}-\mathrm{i}-\mathrm{p}$ and $\mathrm{p}-\mathrm{i}$ n structures (Chen et al., 2015). Pure NiO often suffers from low conductivity, which can be improved by proper doping like Li, $\mathrm{Cu}, \mathrm{Mg}$ (Jung et al., 2015; Yin et al., 2016b). Some NiO films need a high processing temperature. Various efforts have been engaged to lower that temperature. Optical transparency is an another issue needed to be handled to achieve a suitable $\mathrm{NiO}$ film for 
PSCs. High chemical stability of $\mathrm{NiO}$ films promotes the stability of PSC (Wu et al., 2017; Xie et al., 2017; Abzieher et al., 2019).

$\mathrm{Cu}$-based several materials $\mathrm{CuI}, \mathrm{CuSCN}, \mathrm{CuO}, \mathrm{CuS}, \mathrm{CuInS}_{2}$, $\mathrm{CuFeO}_{2}, \mathrm{CuGaO}_{2}$, and $\mathrm{CuCrO}_{2}$ have suitable band alignments to be a HTL of PSCs (Premalal et al., 2012; Subbiah et al., 2014; Chatterjee and Pal, 2016; Arora et al., 2017; Zhang et al., 2018a; Tamilselvan and Bhattacharyya, 2018; Hou et al., 2019a; Akin et al., 2019; Wu et al., 2019a). The conductivity is generally higher than their organic counterparts such as Spiro-OMeTAD. But, they may suffer from high recombination rate, as investigated by ac-impedance spectroscopy (Wang et al., 2016). Thanks to the high hydrophobicity and environment-stability, materials such as CuI can achieve high stability. $93 \%$ of the initial efficiency has been retained after 24 days (Sun et al., 2016a). CuSCN is another attractive candidate owing to its high hole mobility of $0.01-0.1 \mathrm{~cm}^{2} \mathrm{~V}^{-1} \mathrm{~s}^{-1}$ compared to its organic counterparts such as spiro-OMeTAD with a hole mobility of $4 \times 10^{-5} \mathrm{~cm}^{2} \mathrm{~V}^{-1} \mathrm{~s}^{-1}$. High interface contact resistance is an obstacle to achieve satisfactory efficiency. Deposition strategies have been tuned to achieve a compact thin film of CuSCN which leads to less contact resistance and more than $20 \%$ efficiency is achieved (Arora et al., 2017). Degradation at the CuSCN interface with the Au electrode is an important stability issue that has been solved by introducing an additional material such as RGO in between (Arora et al., 2017). We employed an organic molecule 2,3,5,6-tetrafluoro7,7,8,8-tetracyanoquinodimethane to modify the CuSCN interface (Hou et al., 2020a). It helps in avoiding the voltage loss and producing an efficient and stable device. Solutionprocessed $\mathrm{CuO}$ and $\mathrm{Cu}_{2} \mathrm{O}$ show remarkable properties (Sun et al., 2016b; Chatterjee and Pal, 2016). $\mathrm{CuFeO}_{2}, \mathrm{CuGaO}_{2}$, and $\mathrm{CuCrO}_{2}$ have also been proven to be stable hole-transporting materials (Zhang et al., 2018a; Hou et al., 2019a; Akin et al., 2019). High efficiencies of $17.1 \%$ could be achieved and $90 \%$ of the PCE is retained after $200 \mathrm{~h}$. CuSeCN HTL is employed in an inverted planar device which needed solvents much cheaper and less volatile than solvents needed in CuSCN. The device yields $15.97 \%$ PCE and retains $83 \%$ of its efficiency after 20 days in ambient condition (Zhao et al., 2020).

Carbon-based materials can produce stable PSCs as HTL because of their good chemical and thermal stability. Their electronic band structure, suitable Fermi levels, and good conductivity make them suitable candidates to be utilized as the HTL and electrode materials simultaneously (Habisreutinger et al., 2014; Ihly et al., 2016). The carbon-based materials are cost effective, flexible, and with high work function. Those made them suitable for broader applications. Some C-based materials such as single-walled Carbon nanotube can be mixed with other HTLs to enhance their properties (Habisreutinger et al., 2014).

Organic HTLs are widely reported in PSCs literature which can be divided into two parts: 1) Small molecules and 2) Polymers. Spiro-OMeTAD and several of its derivatives are most common of them. The hole mobility values are low, so Li-salts are often added to increase the mobility (Kim et al., 2012).

But, a Li-salt may be prone to absorb water, and thus can be detrimental to stability (Snaith and Grätzel, 2006). A very high price of Spiro-OMeTAD is a major obstacle in the path of commercialization. Fluorinated analogs of Spiro-OMeTAD are found to be hydrophobic and highly effective in hole-transporting owing to favorable shifting of the electronic states. PCE of $24.8 \%$ is achieved with a $\mathrm{V}_{\mathrm{OC}}$ of only $0.3 \mathrm{~V}$ lesser than the theoretical limit (Jeong et al., 2020). Other small molecules are often added with Spiro-OMeTAD to enhance its hole-transporting properties and to increase the stability.

Jen's group utilized a small conjugated molecule, DRSBDT2OT. DRSBDT-2OT, with an acceptor-donor-acceptor structure (Ji et al., 2020). This molecule has a high molecular planarity due to noncovalent intramolecular interactions between $\mathrm{S}$ and $\mathrm{O}$ which leads to low reorganization energy and high hole mobility. When mixed with spiro-OMeTAD, this molecule manifests higher hole mobility due to surface passivation effects in comparison with the spiro-OMeTAD, the mixed HTL-based device exhibits a significantly enhanced efficiency of $21.31 \%$. It also enhances the stability. The mixed hole device retains $82 \%$ of the initial $\mathrm{PCE}$ in ambient condition for a light exposure of $240 \mathrm{~h}$, while the PCE of the control device with only spiro-OMeTAD as HTL reduces to $51 \%$ of the initial efficiency (Figures 5E-I).

In between polymers, PEDOT:PSS is the most commonly used HTL not only for inverted type PSCs, but also for organic solar cells (Jeng et al., 2013). It has several issues, its lower work function than that of perovskites causes a significant amount of potential energy loss. Its acidic nature tends to corrode ITO. So, other polymer derivatives are synthesized to replace it and those could significantly boost the stability (Lim et al., 2014).

Interface engineering is also an intelligent method to boost the efficiency of the device while increasing the stability. We followed this strategy, picked up two most common $\mathrm{HTL} \mathrm{NiO}_{\mathrm{x}}$ and SpiroOMeTAD, and used their combination as the HTL (Li et al., 2020a). Deliberate combination of these two HTL results in $21.6 \%$ PCE in a n-i-p planar device which is higher than that of the only spiro-based device's efficiency of $19.1 \%$. It also enhances the stability (Figures 5B-D). 90\% of the initial PCE could be retained after exposure of 1,200 h. Currently, a significant amount of effort is engaged to enhance the efficiency and stability of the PSCs by intelligent HTL engineering. The representative examples of HTL with good PV performance and excellent stability are listed in Table 3 along with respective stability test information.

\section{Composition Engineering}

Composition engineering of the perovskite is proven to be a successful approach to enhance the efficiency and stability. In many cases, one step taken to change the composition leads to improvement of various stability issues. In perovskite materials such as $\mathrm{MAPbI}_{3}$, the conduction band minimum is generally directed by the $\mathrm{p}$ orbital of $\mathrm{Pb}$, and the valence band maximum by the $\mathrm{s}$ and $\mathrm{p}$ orbitals of $\mathrm{Pb}$ and the $\mathrm{p}$ orbital of I (Yin et al., 2014). The A site cation contributes to the deep energy levels but not to the band edges. The change in A-site does not change the optical or optoelectronic properties. So, the A-site can easily be engineered to tune other physical properties such as thermal stability without affecting the light-harvesting efficiency, which depends on the bandgap. FA can make stronger bonds with the $\mathrm{PbX}_{6}$ octahedra than that of MA because it has more number of $\mathrm{H}$, which make stronger $\mathrm{H}$-bonding with $\mathrm{PbX}_{6}$ (Amat et al., 
TABLE 3 | Effect of hole-transporting layers on efficiency and stability of PSC.

\begin{tabular}{|c|c|c|c|c|}
\hline HTL & Device configuration & $\begin{array}{l}\text { PCE } \\
(\%)\end{array}$ & Stability & References \\
\hline $\mathrm{NiO}_{x}$ & FTO/NiMgLiO ${ }_{x} / \mathrm{MAPb}_{3} / \mathrm{PCBM} / \mathrm{Ti}(\mathrm{Nb}) \mathrm{O}_{x} / \mathrm{Ag}$ & 20.4 & $\begin{array}{l}<10 \% \text { PCE drop after continuous light soaking for } 1,000 \text { h at } \\
\text { short-circuit point, } 25^{\circ} \mathrm{C}, \mathrm{RH}<25 \% ;<20 \% \text { PCE drop after } \\
500 \mathrm{~h} \text { thermal stress at } 85^{\circ} \mathrm{C} \text { in the dark, } \mathrm{RH}<25 \%\end{array}$ & Wu et al. (2017) \\
\hline $\mathrm{NiO}_{x}$ & $\begin{array}{l}\text { ITO/NiO }{ }_{x} / \mathrm{Cs}_{0.10}\left(\mathrm{FA}_{0.83} \mathrm{MA}_{0.17}\right)_{0.90} \mathrm{~Pb}\left(\mathrm{Br}_{0.15} \mathrm{I}_{0.85}\right)_{3} / \\
\mathrm{C} 60 / \mathrm{BCP} / \mathrm{Au}\end{array}$ & 17.7 & $\begin{array}{l}<17 \% \text { PCE drop after continuous intensive UV-light soaking } \\
\text { for } 4,100 \mathrm{~h} \text {, inert atmosphere. }<2 \% \text { PCE drop during } 40 \text { h of } \\
\text { MPP tracking at } 75^{\circ} \mathrm{C}\end{array}$ & $\begin{array}{l}\text { Abzieher et al. } \\
(2019)\end{array}$ \\
\hline $\mathrm{NiO}_{x}$ & FTO/NiMgLiO ${ }_{x} / \mathrm{FAMAPb}_{3} / \mathrm{PCBM} / \mathrm{Ti}(\mathrm{Nb}) \mathrm{O}_{x} / \mathrm{Ag}$ & 20.6 & $\begin{array}{l}15 \% \text { PCE drop after continuous light soaking for } 500 \mathrm{~h} \text { at } \\
\text { MPPT, ambient condition, encapsulated; }<10 \% \text { PCE drop } \\
\text { after } 500 \mathrm{~h} \text { thermal stressed at } 85^{\circ} \mathrm{C} \text { in the dark, ambient } \\
\text { condition }\end{array}$ & Xie et al. (2017) \\
\hline CuSCN & $\mathrm{FTO} / \mathrm{meso}^{-\mathrm{TiO}_{2}} / \mathrm{CsFAMAPbl}_{3-\mathrm{x}} \mathrm{Br}_{x} / \mathrm{CuSCN}-\mathrm{rGO} / \mathrm{Au}$ & 20.2 & $\leq 5 \%$ PCE drop for $>1,000 \mathrm{~h}$ at MPPT, $\mathrm{N}_{2}, 60^{\circ} \mathrm{C}$ & $\begin{array}{l}\text { Arora et al. } \\
(2017)\end{array}$ \\
\hline CuSCN & $\mathrm{FTO} / \mathrm{c}-\mathrm{TiO}_{2} / \mathrm{mp}-\mathrm{TiO}_{2} /$ perovskite/CuSCN/CNT/C & 17.6 & $\leq 5 \%$ PCE drop for $>1,000 \mathrm{~h}$ at MPPT, $\mathrm{N}_{2}$ & Wu et al. (2019a) \\
\hline $\mathrm{CuGaO}_{2}$ & $\begin{array}{l}\mathrm{FTO} / \mathrm{NiO}_{x} / \mathrm{CuGa}(\mathrm{Zn}) \mathrm{O}_{2} / \mathrm{Cs}_{0.15} \mathrm{FA}_{0.85} \mathrm{~Pb}\left(\mathrm{I}_{0.9} \mathrm{Br}_{0.1}\right)_{3} / \\
\mathrm{PCBM} / \mathrm{BCP} / \mathrm{Ag}\end{array}$ & 20.7 & $\begin{array}{l}<15 \% \text { PCE drop after } 1,000 \mathrm{~h}, 85^{\circ} \mathrm{C} \text { in dark, inert } \\
\text { atmosphere }\end{array}$ & $\begin{array}{l}\text { Hou et al. } \\
(2019 a)\end{array}$ \\
\hline $\mathrm{CuCrO}_{2}$ & ITO/CuCrO $2 / \mathrm{MAPbl}_{3} / \mathrm{PCBM} / \mathrm{BCP} / \mathrm{Ag}$ & 19 & $\begin{array}{l}<10 \% \text { PCE drop after continuous intensive UV-light soaking } \\
\text { for } 1,000 \mathrm{~h} \text {, inert }\end{array}$ & $\begin{array}{l}\text { Zhang et al. } \\
\text { (2018a) }\end{array}$ \\
\hline $\mathrm{CuFeO}_{2}$ & $\begin{array}{l}\mathrm{FTO} / \mathrm{c}-\mathrm{TiO}_{2} / \mathrm{m}-\mathrm{TiO}_{2} / \mathrm{Cs}_{0.05} \\
\left(\mathrm{MA}_{0.15} \mathrm{FA}_{0.85}\right)_{0.95} \mathrm{~Pb}\left(\mathrm{l}_{0.85} \mathrm{Br}_{0.15}\right)_{3} / \mathrm{CuFeO}_{2} / \mathrm{Au}\end{array}$ & 15.2 & $\leq 5 \%$ PCE drop for $>1,000 \mathrm{~h}$ at MPPT, $\mathrm{N}_{2}$ & Akin et al. (2019) \\
\hline $\begin{array}{l}\text { P3HT with a wide } \\
\text { bandgap halide layer }\end{array}$ & $\begin{array}{l}\mathrm{FTO} / \mathrm{c}-\mathrm{TiO}_{2} / \mathrm{m}^{-\mathrm{TiO}_{2}} /\left(\mathrm{FAPbl}_{3}\right)_{0.95}\left(\mathrm{MAPbBr}_{3}\right)_{0.05} / \\
\text { WBH/P3HT/Au }\end{array}$ & 22.7 & $\leq 5 \%$ PCE drop for $>1,370 \mathrm{~h}$ at MPPT, $25^{\circ} \mathrm{C}, \mathrm{RH}=30 \%$ & $\begin{array}{l}\text { Jung et al. } \\
\text { (2019) }\end{array}$ \\
\hline $\begin{array}{l}\text { Spiro-OMeTAD/(Zn- } \\
\left.\text { TFSI }_{2}\right)\end{array}$ & $\begin{array}{l}\text { FTO/Ru-doped } \mathrm{SnO}_{2} / \text { perovskite/spiro-OMeTAD(Zn- } \\
\text { TFSI2)/Au }\end{array}$ & 21.8 & $\leq 5 \%$ PCE drop for $>1,000 \mathrm{~h}$ at MPPT, $\mathrm{N}_{2}$ & Akin (2019) \\
\hline HTL free & ITO/MAPbI $3 / \mathrm{C}_{60} / \mathrm{BCP} / \mathrm{Ag}$ & $16.9 \%$ & 93\% PCE retained after 1,000 $\mathrm{h}$ light soaking at MPPT & $\begin{array}{l}\text { Zhou et al. } \\
\text { (2019a) }\end{array}$ \\
\hline
\end{tabular}

2014). So, the thermal stability increases (Eperon et al., 2014; Pering et al., 2017). Replacing the A-site by an inorganic species such as $\mathrm{Cs}^{+}$can further improve the thermal stability because it can make primary bonding with $\mathrm{PbX}_{6}$ which is much stronger than H-bonds (Lee et al., 2014a; Ma et al., 2020a). Thermodynamic instability of $\mathrm{FAPbI}_{3}$ and $\mathrm{CsPbI}_{3}$ is a barrier to use them in PSCs as non-perovskite phases often occur ( $\mathrm{Li}$ et al., 2016a; Lin et al., 2018). The tolerance factor of $\mathrm{FAPbI}_{3}$ has a high value and it is more stable in the hexagonal $\delta_{H}$ phase (yellow phase), and the $\delta_{H}$ to $\alpha$ phase-transition temperature is higher than room temperature. $\mathrm{CsPbI}_{3}$ is stabilized to an orthorhombic structure $\left(\delta_{O}\right.$ phase) at room temperature because its tolerance factor is low (Li et al., 2016a). Using alloyed perovskite is an effective strategy to increase the thermal stability while keeping up the structural stability of the perovskite (Hou et al., 2019a). Thin film of alloyed perovskite $\mathrm{FA}_{0.85} \mathrm{Cs}_{0.15} \mathrm{PbI}_{3}$ demonstrated improved stability in a highly humid environment (Li et al., 2016a). In alloyed perovskites, more than one species are used in the A-site. The calculation of tolerance factor of the alloyed perovskite is discussed in Intrinsic Stability. Increased thermal stability of alloyed perovskites contributes to the stability of the PSC. 5-20\% of Cs content can increase the thermal stability (Lee et al., 2015). The strategy of alloying is also important. We adopted a method of posttreatment where FAI solution in isopropanol is used to treat the perovskite film (Xin et al., 2020). It is proven to be highly effective in passivating the defects. The posttreatment particularly targets the defective grain boundaries of the crystalline perovskite film. 20.62\% PCE could be achieved compared to the $19.26 \%$ of the control device. The FAI post-treated device retains $95 \%$ of the initial
PCE after 60 days of storage under $\mathrm{N}_{2}$ and $78 \%$ of the PCE after 30 days of storage in ambient condition. Achieving stable perovskite phase for $\mathrm{FAPbI}_{3}$ is a big challenge due to thermodynamic factors, as discussed in Structural Stability and Thermodynamic Phase Stability. It is predicted that $\mathrm{FAPbI}_{3}$ can be more efficient in solar energy conversion than $\mathrm{MAPbI}_{3}$. Graetzel et al used a vapor-assisted method, MASCN or FASCN is used to convert yellow $\delta$-phase $\mathrm{FAPbI}_{3}$ into black $\alpha$-phase $\mathrm{FAPbI}_{3}$, which is also stable (Lu et al., 2020). This phase transition should take high temperature, but it can be carried out at $150^{\circ} \mathrm{C}$ in the presence of $\mathrm{SCN}^{-}$ion. The $\mathrm{SCN}^{-}$attached on the surface and started to form the $\alpha$-phase, then it continued to the bulk. Once the $\alpha$-phase is formed, it cannot convert back into the $\delta$-phase due to high energy barrier. The $\alpha$-phase black $\mathrm{FAPbI}_{3}$ results in $\mathrm{PCE}>$ $23 \%$ and good stability.

Bulkier cation than that of FA like guanidinium (GA) has been used to alloy with MA (Jodlowski et al., 2017; Ding et al., 2021). The formation energy is lower than that of the FA alloy. So, the thermodynamic stability of the perovskite increases. The device manifests good environmental stability even at $60^{\circ} \mathrm{C}$ temperature and continuous solar light illumination. Other $\mathrm{N}$-containing larger groups are used to alloy with MA. The devices show enhanced operational stability in ambient conditions. Ferdani et al proposed that bigger $\mathrm{A}$-site cations can resist the iodide migration which is also large in size, and thus enhance the stability (Ferdani et al., 2019). Methylenediammonium (MDA) and $\mathrm{Cs}^{+}$cations are used simultaneously to alloy with $\mathrm{FAPbI}_{3}$, these two cations relieve the strain on $\mathrm{FAPbI}_{3}$ crystal, and thus facilitate the formation of $\alpha$-phase $\mathrm{FAPbI}_{3}$. More than 25\% PCE is achieved with satisfactory stability (Kim et al., 2020a). 

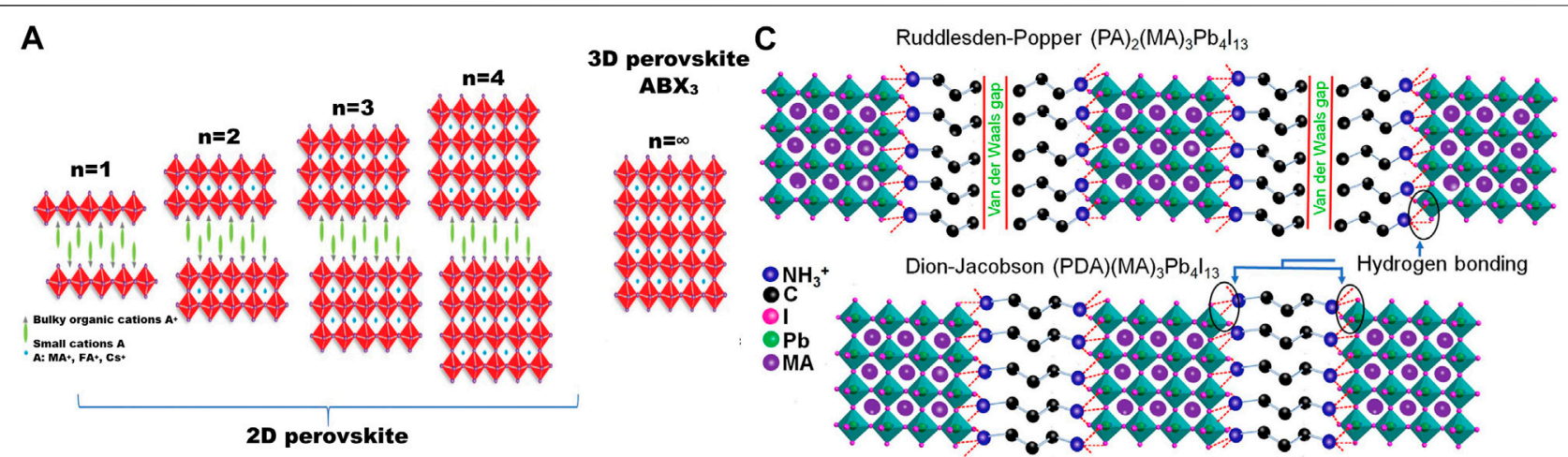

B
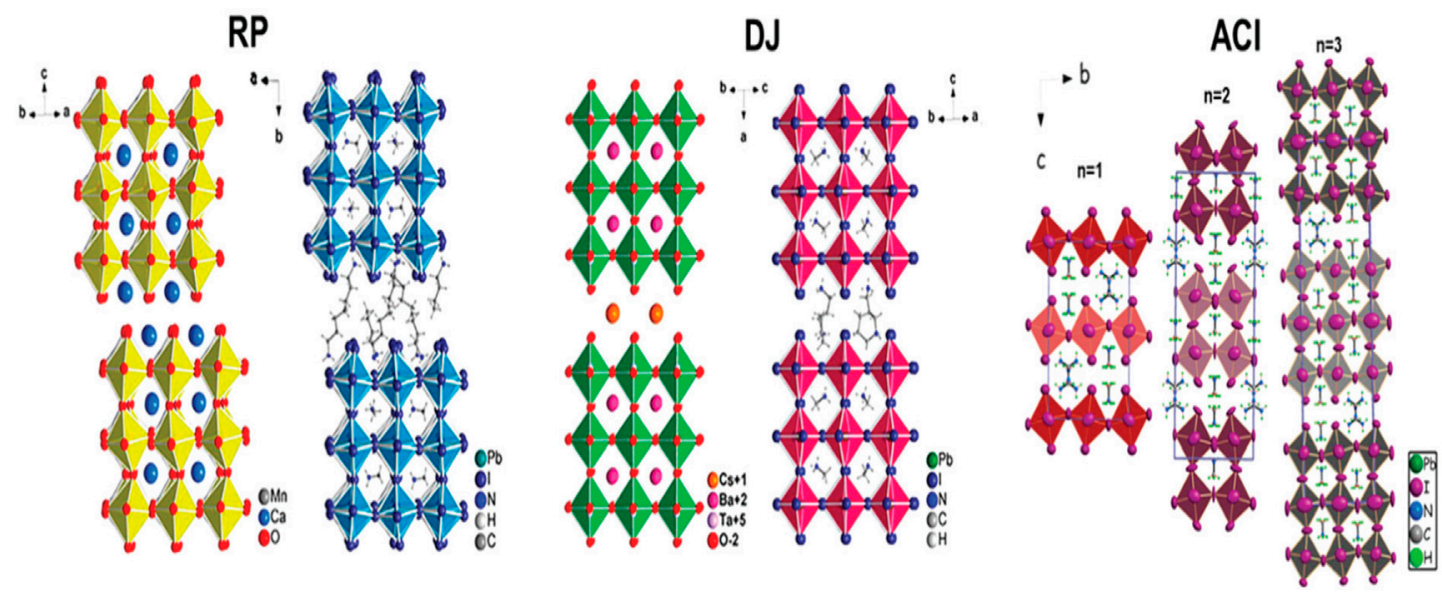

FIGURE 6 | (A) Schematic of evolution of perovskite from 2D to 3D with increasing $n$, the thickness of the layer (Zhang et al., 2020). Reproduced with permission. Copyright 2020, Royal Society of Chemistry. (B) Examples of RP- $\mathrm{Ca}_{4} \mathrm{Mn}_{3} \mathrm{O}_{10}$ (left), (BA) $)_{2}(\mathrm{MA})_{2} \mathrm{~Pb}_{3} \mathrm{l}_{10}\left(n=3\right.$; right); DJ-CsBa $\mathrm{Ta}_{3} \mathrm{O}_{10}(\mathrm{left})$ and $(3 \mathrm{AMP})(\mathrm{MA})_{2} \mathrm{~Pb}_{3} \mathrm{l}_{10}$ ( $n=3$; right) and ACl- (Gua)(MA) ${ }_{n} \mathrm{~Pb}_{n} \mathrm{I}_{3 n+1}(n=1,2$, 3) (Soe et al., 2017; Mao et al., 2018). Reproduced with permission. Copyrights -2017 and 2018 , American Chemical Society. (C) Comparison of hydrogen bonding in RP and DJ 2D perovskites (Ahmad et al., 2019). Reproduced under the terms of Elsevier user license. Copyright 2019, Elsevier Publishing.

Partial substitution of the $\mathrm{X}$-site iodide by other halide is also a strategy of composition engineering of the perovskite. But, it must be done with great care because it may cause change of optoelectronic properties of perovskite (Juarez-Perez et al., 2016). Substitution of $\mathrm{I}^{-}$by $\mathrm{Br}^{-}$and $\mathrm{Cl}^{-}$increases the bandgap, thus decreasing the photocurrent. So, a limited amount of substitution is done which increases the interaction of the halide with the $\mathrm{PbI}_{6}$ octahedra, thus increasing the stability. Multi-cation and multi-halide systems are also reported with enhanced stability (Saliba et al., 2016a; Saliba et al., 2016b). We reported a quasi-heteroface PSCs by a double-layered perovskite film where perovskites with two different bandgaps are used which are achieved by tuning the content of halides (Ren et al., 2020). An additional built-in electric field has been detected which helps in the enhancement of PCE and stability. A $\mathrm{Cs}_{0.15} \mathrm{FA}_{0.85} \mathrm{PbI}_{3} / \mathrm{Cs}_{\mathrm{x}} \mathrm{FA}_{1-\mathrm{x}} \mathrm{PbI}_{3}$ core-shell heterostructure with a Cs-rich $\mathrm{Cs}_{\mathrm{x}} \mathrm{FA}_{1-\mathrm{x}} \mathrm{PbI}_{3}$ quasi-shell structure is proven to be effective in reducing defect density and suppressing ion migration. 20.7\% PCE is achieved and the encapsulated device retains $95 \%$ of its initial PCE after $1,000 \mathrm{~h}$ of continuous operation, a projected lifetime of $\sim 2$ years (Peng et al., 2020). $\mathrm{McGehee}$ et al studied device performance and photostability across a compositional space of FA and Cs at the A-site at various halide compositions. It is observed that increasing $\mathrm{Cs}$ at the $\mathrm{A}$-site rather than more $\mathrm{Br}$ at the $\mathrm{X}$-site to raise perovskite band gap is more useful to improve both $\mathrm{V}_{\mathrm{OC}}$ and photostability (Bush et al., 2018). Intelligent tuning of halide content has been proven to be beneficial. Kang et al employed a double-halide passivation strategy by varying the concentration of precursors $\mathrm{MACl}$ and $\mathrm{MABr}$ to engineer the morphology, intrinsic defects, and optical band gap of the perovskite. Better-aligned energy levels, suppressed grain boundary recombination losses, and cascade charge transfer yielded a device with PCE of $20.3 \%$ with excellent air, photo, and thermal stabilities (Tyagi et al., 2020). All-inorganic PSCs are highly stable and improving their efficiency can be a key to achieve commercial PSCs (Duan et al., 2019; Zhou et al., 2020; Du et al., 2021).

Although many authors treat dimensional engineering of perovskite as "additive engineering," dimensional engineering arises from change in certain component of the perovskite. So, this is discussed in this section. In the previous part, we discussed how substitution of A-site by bulkier cation can increase the stability. But, with increasing size of A-site moiety, the distance between the $\mathrm{BX}_{6}$ octahedra also increases and after a certain 
point, 3D corner-sharing geometry becomes impossible. Hence, the structure would become $2 \mathrm{D}$, layered $\mathrm{BX}_{6}$ octahedra intercalated with bulky A-site anions. The evolution of $3 \mathrm{D}$ perovskite from $2 \mathrm{D}$ also can be represented in terms of the thickness of the layer $n$. The $2 \mathrm{D}$ perovskite can be represented by a formula $\left(\mathrm{A}^{\prime}\right)_{m}(A)_{n-}$ ${ }_{1} \mathrm{~B}_{\mathrm{n}} \mathrm{X}_{3 \mathrm{n}+1}$, where $\mathrm{A}^{\prime}$ can be divalent $(m=1)$ or monovalent $(m=2)$ cations that form a bilayer or monolayer connecting the inorganic $(A)_{n-1} B_{n} X_{3 n+1} 2 D$ sheets; the layer thickness of metal halide sheets is denoted by $n$ and that can be adjusted by tuning precursor composition (Yuan et al., 2016; Zhou et al., 2018). A large, high aspect ratio organic cation can take the $\mathrm{A}^{\prime}$ site. The ideal $2 \mathrm{D}$ perovskite is where $n=1$. When $1<n \leq 5$, the species is labeled as quasi-2D. A mixture of $3 \mathrm{D}$ perovskite and lower $n$-phase $(n \leq 3)$ can form in case of high $n$-values $(n=30-60)$; these are called quasi-3D perovskite. When the layer is continuous, i.e., the layer thickness tends to infinity $(n=\infty)$, it is a 3D perovskite (Mei et al., 2014). The evolution of perovskite from $2 \mathrm{D}$ to $3 \mathrm{D}$ with respect to $n$ is described by a schematic in Figure 6A. 2D halide perovskite layers can hypothetically be obtained by cutting the corresponding $3 \mathrm{D}$ perovskite along $\langle 100\rangle,\langle 110\rangle,\langle 111\rangle$ crystallographic planes, which would orient the $2 \mathrm{D}$ perovskite along the plane it has been cut through. The $\langle 111>$ oriented $2 \mathrm{D}$ perovskites have a formula $\mathrm{A}^{\prime}{ }_{2} \mathrm{~A}_{\mathrm{q}-1} \mathrm{~B}_{\mathrm{q}} \mathrm{X}_{3 \mathrm{q}+2}(\mathrm{q}>1)$ and can only be constructed from group 15 $\mathrm{B}^{3+}$ ions (e.g., Bi, Sb, As) (Vargas et al., 2018). They are often efficient in solar photon harvesting owing to their p-type like character and smaller effective masses for electron and hole. In 2D or quasi-2D perovskites, the bandgaps are higher than that of their $3 \mathrm{D}$ counterpart and may not be suitable to be an efficient light harvester. But, those have superior moisture and thermal stability than that of their 3D counterpart because the hydrophobic big A-site cation minimizes surface energy of the crystal. 2D and 3D perovskites are often mixed and that forms quasi-2D perovskite where $2 \mathrm{D}$ and $3 \mathrm{D}$ crystals are periodically repeated. Addition of $2 \mathrm{D}$ perovskite can greatly enhance the stability of the PSCs due to its superior stability under heat, moisture, and light (Tsai et al., 2016). Also, ion migration is suppressed in quasi-2D perovskite due to larger activation energies for the formation of point defect. Liu's group has reported highly efficient 2D/3D PSCs (Huang et al., 2019a). 2D perovskites can be further classified into RuddlesdenPopper (RP), Dion-Jacobson (DJ) phases and phases with alternating cations in the interlayer space (ACI) ( $\mathrm{Li}$ et al., 2019b; Paritmongkol et al., 2019; Zhang et al., 2019c). These three phases are explained in Figure 6B. A RP phase 2D perovskite is generally represented by formula $A^{\prime}{ }_{2} A_{n-1} B_{n} X_{3 n+1}$, where $\mathrm{A}^{\prime}$ is an aryl ammonium or an alkyl cation. Comparatively weak van der Waals gap forms between a bilayer of monovalent cations and two adjacent lead halide sheets (Paritmongkol et al., 2019). DJ phase perovskite can be represented by $A^{\prime} A_{n-1} B_{n} X_{3 n+1}$, where $A^{\prime}$ is a diamine. $A$ diamine compound is employed and the two amino groups from the same moiety make H-bonding with two ends of two adjacent metal halide sheets. This makes the DJ phase more stable (Li et al., 2019b). The ACI phase perovskite has formula $A^{\prime} A_{n} B_{n} X_{3 n+1}$, where the large $A^{\prime}$ cation fills the interlayer and the small $\mathrm{A}$ cation resides in the metal halide sheets (Zhang et al., 2019c). The H-bonding characters in the RP and DJ phases with the metal-halide are described in Figure 6C.
A large spacer cation 2-thiophenemethylammonium is incorporated into the $3 \mathrm{D}$ perovskite to form a $2 \mathrm{D} / 3 \mathrm{D}$ hybrid structure (Lai et al., 2018; Zhou et al., 2019b). It induces crystalline growth and orientation, passivation of trap states, and hindering the motion of ions. This helps in improved carrier lifetime and reduced recombination losses. It yields $21.49 \%$ PCE and the encapsulated device retains $99 \%$ of PCE even after $1,680 \mathrm{~h}$ of operation under ambient condition. The suppressed ion migration results in operational stability of 1 year. A novel 2D RP perovskite (AA) ${ }_{2} \mathrm{MA}_{3} \mathrm{~Pb}_{4} \mathrm{I}_{13}$ yields $18.42 \%$ efficiency (Wu et al., 2020a). Phenylethylammonium is used to facilitate formation as well as control of $2 \mathrm{D}$ perovskite, which is also able to suppress charge recombination in $\mathrm{CsPbI}_{3}$. The device achieved $17 \%$ PCE and $94 \%$ of it could be retained over $2000 \mathrm{~h}$ of storage under low humidity (Ye et al., 2020). A molten salt spacer $n$-butylamine acetate is proven to be made a strong coordination bond with the perovskite and a phase-pure quantum well film is formed with vertically aligned micro-grains. The device yields $16.25 \%$ efficiency, $1.31 \mathrm{~V}$ of $\mathrm{V}_{\text {OC. }}$. It retains $\sim 90 \%$ efficiency under $65 \pm 10 \%$ humidity for $4,680 \mathrm{~h}$, under operation at $85^{\circ} \mathrm{C}$ for $558 \mathrm{~h}$, or continuous light illumination for $1,100 \mathrm{~h}$ (Liang et al., 2021). Fluoroarene-based RP 2D perovskite can highly stabilize the device owing to the ultra-hydrophobicity of pentafluorophenylethylammonium spacer cation (Liu et al., 2019). Large area PSC module could be fabricated with excellent ambient- and photo-stability when 4-fluorophenethylammonium iodide has been employed (Lee et al., 2021). Aromatic formamidiniums are proven to be effective spacer due to its ability to make multiple NH...I hydrogen bonds between itself and the $\left(\mathrm{PbI}_{6}\right)^{4-}$. Chen's group employed benzamidine hydrochloride as a spacer and a highly efficient device is achieved with PCE $=23.36 \%$ and long-term thermal stability under $80^{\circ} \mathrm{C}$, over $1,400 \mathrm{~h}$ operation (Liu et al., 2021a).

Presence of $2 \mathrm{D}$ perovskite in a light harvester $3 \mathrm{D}$ perovskite may affect the transportation of the photogenerated charges. To avoid this, 2D-3D heterostructures are introduced (Wang et al., 2017c; Lee et al., 2018a). The 2D perovskite spontaneously segregated at the grain boundary with the $3 \mathrm{D}$ perovskite. So, it can reduce the loss due to recombination, but it does not affect the charge transport. These help in the improvement of both performance and stability. A stable and highly crystalline 2D $\left(\mathrm{C}_{4} \mathrm{H}_{9} \mathrm{NH}_{3}\right)_{2} \mathrm{PbI}_{4}$ film is grown on the top of a $3 \mathrm{D}$ film using a solvent-free solid-phase in-plane growth method. A high built-in potential is observed at the $2 \mathrm{D} / 3 \mathrm{D}$ heterojunction which results in high photovoltage. A steady-state efficiency of $24.35 \%$ is achieved and the encapsulated device could retain $94 \%$ of the initial PCE after $1,056 \mathrm{~h}$ under the damp heat test $\left(85^{\circ} \mathrm{C} / 85 \%\right.$ relative humidity) and $98 \%$ after $1,620 \mathrm{~h}$ under full-sun illumination (Jang et al., 2021a).

Though DJ phase 2D perovskites are more stable than those of their RP counterparts, the devices lack in efficiency. A device based on DJ phase (PDA) $(\mathrm{MA})_{\mathrm{n}-1} \mathrm{~Pb}_{\mathrm{n}} \mathrm{I}_{3 \mathrm{n}+1} 2 \mathrm{D}$ perovskite yielded 13.3\% PCE but manifested exceptional stability. More than $95 \%$ of PCE has been retained after $168 \mathrm{~h}$ of damp-heat test $\left(85^{\circ} \mathrm{C}, \mathrm{RH}\right.$ $=85 \%$ ) and $4,000 \mathrm{~h}$ operation in ambient (Ahmad et al., 2019). 1,4-butanediamine iodide-based DJ perovskite yields in a PSC with $17.91 \%$ efficiency and good stability (Niu et al., 2019). 
TABLE 4 | Additive engineering on PSCs. Representative additives with the performance in PSCs.

\begin{tabular}{|c|c|c|c|c|c|}
\hline Type & Additive & Device configuration & $\begin{array}{l}\text { PCE } \\
(\%)\end{array}$ & Stability & References \\
\hline Lewis acid & $\mathrm{Pbl}_{2}$ & $\begin{array}{l}\mathrm{FTO} / \mathrm{C}-\mathrm{TiO}_{2} / \mathrm{m}-\mathrm{TiO}_{2} /\left(\mathrm{FAPbl}_{3}\right)_{0.85}\left(\mathrm{MAPbBr}_{3}\right)_{0.15} / \text { spiro- } \\
\text { OMeTAD/Au }\end{array}$ & 20.1 & $\mathrm{~N} / \mathrm{A}$ & Kim et al. (2016) \\
\hline Lewis acid & $\mathrm{Pbl}_{2}$ & $\mathrm{FTO} / \mathrm{SnO}_{2} / \mathrm{FAO} .9 \mathrm{Cs}_{0.1} \mathrm{~Pb}\left(\mathrm{IO} .9 \mathrm{Br}_{0.1}\right)_{3} /$ spiro-OMeTAD/Au & 22 & $72 \%$ after $360 \mathrm{~h}$ constant illumination at MPP & $\begin{array}{l}\text { Yang et al. } \\
\text { (2020b) }\end{array}$ \\
\hline Lewis acid & $\mathrm{KI}$ & $\begin{array}{l}\text { ITO/c-TiO } / \mathrm{m}-\mathrm{TiO}_{2} / \mathrm{Cs}_{0.06} \mathrm{FA}_{0.79} \mathrm{MA}_{0.15} \mathrm{~Pb}\left(\mathrm{I}_{0.85} \mathrm{Br}_{0.15}\right)_{3} / \\
\text { spiro-OMeTAD/Au }\end{array}$ & 21.5 & $\begin{array}{l}80 \% \text { after } 300 \text { h of continuous operation } \\
\text { at MPP }\end{array}$ & $\begin{array}{l}\text { Abdi-Jalebi et al. } \\
(2018 a)\end{array}$ \\
\hline Lewis acid & $\mathrm{NaF}$ & $\begin{array}{l}\mathrm{FTO} / \mathrm{SnO}_{2} /\left(\mathrm{Cs}_{0.05} \mathrm{FA}_{0.54} \mathrm{MA}_{0.41}\right) \mathrm{Pb}\left(\mathrm{l}_{0.98} \mathrm{Br}_{0.02}\right)_{3} / \text { spiro- } \\
\text { OMeTAD/Au }\end{array}$ & 21.5 & $\begin{array}{l}90 \% \text { after } 1,000 \mathrm{~h} \text { of continuous operation } \\
\text { at MPP }\end{array}$ & Li et al. (2019c) \\
\hline Lewis acid & $\mathrm{NaCl}$ & $\mathrm{NaCl}$-doped $\mathrm{TiO}_{2} / \mathrm{FA}_{0.85} \mathrm{MA}_{0.15} \mathrm{Pbl}_{3} /$ spiro-MeOTAD/Au & 19.9 & $80 \%$ after $800 \mathrm{~h}$ air storage & Li et al. (2020c) \\
\hline Lewis acid & $\mathrm{Eu}^{3+}$ & $\mathrm{FTO} / \mathrm{SnO}_{2} /(\mathrm{FA}, \mathrm{MA}, \mathrm{Cs}) \mathrm{Pb}(\mathrm{l}, \mathrm{Br})_{3}(\mathrm{Cl}) /$ spiro-OMeTAD/Au & 21.5 & $\begin{array}{l}91 \% \text { after } 500 \text { h of continuous operation } \\
\text { at MPP }\end{array}$ & $\begin{array}{l}\text { Wang et al. } \\
\text { (2019d) }\end{array}$ \\
\hline Lewis acid & $\mathrm{Rbl}$ & $\begin{array}{l}\mathrm{FTO} / \mathrm{c}-\mathrm{TiO}_{2} / \mathrm{m}-\mathrm{TiO}_{2} /(\mathrm{CsFAMA}) \mathrm{Pb}(\mathrm{IBr})_{3} / \text { spiro- } \\
\text { OMeTAD/Au }\end{array}$ & 21.8 & $\begin{array}{l}95 \% \text { after } 500 \text { h of continuous operation at } \\
\text { MPP }, 85^{\circ} \mathrm{C}\end{array}$ & $\begin{array}{l}\text { Saliba et al. } \\
(2016 b)\end{array}$ \\
\hline Lewis acid & $\mathrm{Cdl}_{2}$ & $\begin{array}{l}\text { ITO/PTAA/Rb }{ }_{0.025} \mathrm{Cs}_{0.025} \mathrm{FA}_{0.70} \mathrm{MA}_{0.25} \mathrm{Pbl}_{3} / \mathrm{C}_{60^{-}} \\
\mathrm{BCP} / \mathrm{Cu}\end{array}$ & 21.9 & $\begin{array}{l}92 \% \text { after } 1,000 \mathrm{~h} \text { constant illumination } \\
\text { at MPP }\end{array}$ & Wu et al. (2020b) \\
\hline Lewis acid & $\mathrm{C}_{60}$ & $\begin{array}{l}\text { ITO/PEDOT:PSS/ } \mathrm{CH}_{3} \mathrm{NH}_{3} \mathrm{~Pb}_{0.75} \mathrm{Sn}_{0.25} \mathrm{I}_{3} / \mathrm{PCBM} / \\
\mathrm{BCP} / \mathrm{Al}\end{array}$ & 13.9 & $80 \%$ after 168 h, dark, $\mathrm{RH}=30-50 \%$ & Liu et al. (2017) \\
\hline Lewis acid & a-bis-PCBM & $\begin{array}{l}\mathrm{FTO} / \mathrm{c}-\mathrm{TiO}_{2} / \mathrm{m}-\mathrm{TiO}_{2} / \mathrm{FA}_{0.85} \mathrm{MA}_{0.15} \mathrm{~Pb}\left(\mathrm{l}_{0.85} \mathrm{Br}_{0.15}\right)_{3} / \text { spiro- } \\
\text { OMeTAD/Au }\end{array}$ & 20.8 & $\begin{array}{l}95 \% \text { after } 600 \mathrm{~h} \text { of continuous light soaking } \\
\text { at MPP }\end{array}$ & Zhang et al. (2017) \\
\hline Lewis acid & $\mathrm{C}_{60}-\mathrm{PEG}$ & ITO/NiO ${ }_{x} / \mathrm{Cs}_{0.1} \mathrm{FA}_{0.7} \mathrm{MA}_{0.2} \mathrm{I}_{3-\mathrm{x}} \mathrm{Br}_{x} / \mathrm{PCBM} / \mathrm{BCP} / \mathrm{Al}$ & 17.7 & $93 \%$ after $960 \mathrm{~h}$ in dark & Fu et al. (2019) \\
\hline Lewis acid & TPFP & $\begin{array}{l}\text { ITO/SnO } / \mathrm{Cs}_{0.05} \mathrm{FA}_{0.8} \mathrm{MA}_{0.15} \mathrm{~Pb}\left(\mathrm{l}_{0.83} \mathrm{Br}_{0.17}\right)_{3} / \text { Spiro- } \\
\text { OMeTAD/Au }\end{array}$ & 24 & $80 \%$ after 14 days in dark, $\mathrm{RH}=85 \%$ & $\begin{array}{l}\text { Yang et al. } \\
\text { (2020b) }\end{array}$ \\
\hline Lewis acid & $L A D$ & $\mathrm{FTO} / \mathrm{c}-\mathrm{TiO}_{2} / \mathrm{m}-\mathrm{TiO}_{2} / \mathrm{CsFAMA} / \mathrm{PTAA} / \mathrm{Au}$ & 23 & $93 \%$ after $1,500 \mathrm{~h}$ in ambient & Luo et al. (2020) \\
\hline Lewis acid & TPFPB & $\mathrm{FTO} / \mathrm{NiOx} / \mathrm{CsPb} / 2 \mathrm{Br} / \mathrm{ZnO} / \mathrm{C}_{60} / \mathrm{Ag}$ & 15.9 & $\begin{array}{l}92 \% \text { after } 72 \text { days of continuous operation in } \\
\text { ambient }\end{array}$ & Peng et al. (2020) \\
\hline Lewis base & Pyridine & $\begin{array}{l}\mathrm{FTO} / \mathrm{C}-\mathrm{TiO}_{2} / \mathrm{Cs}_{0.05}\left(\mathrm{MA}_{0.17} \mathrm{FA}_{0.83}\right)_{0.95} \mathrm{~Pb}\left(\mathrm{l}_{0.83} \mathrm{Br}_{0.17}\right)_{3} / \\
\text { spiro-OMeTAD/Au }\end{array}$ & 19 & $\mathrm{~N} / \mathrm{A}$ & Liu et al. (2018b) \\
\hline Lewis base & butylpyridine & $\mathrm{FTO} / \mathrm{c}-\mathrm{TiO}_{2} / \mathrm{m}-\mathrm{TiO}_{2} / \mathrm{MAPbl}_{3} /$ spiro-OMeTAD/Au & 17.4 & $89 \%$ after $720 \mathrm{~h}$ in dark & Wu et al. (2018) \\
\hline Lewis base & $6 \mathrm{TIC}-4 \mathrm{~F}$ & $\mathrm{ITO} / \mathrm{NiO}_{x} / \mathrm{CsPb}_{x} \mathrm{Br}_{3-x} / \mathrm{ZnO} / \mathrm{C}_{60} / \mathrm{Ag}$ & 17.7 & $85 \%$ after $350 \mathrm{~h}$ continuous light soaking & Wu et al. (2020b) \\
\hline Lewis base & DMSO & $\mathrm{FTO} / \mathrm{c}-\mathrm{TiO}_{2} / \mathrm{MAPb}_{3} /$ spiro-OMeTAD/Au & 19.7 & N/A & Ahn et al. (2015) \\
\hline Lewis base & PMMA & $\mathrm{FTO} / \mathrm{c}-\mathrm{TiO}_{2} / \mathrm{m}-\mathrm{TiO}_{2} / \mathrm{MAPbl}_{3} /$ spiro-OMeTAD/Au & 21.6 & $80 \%$ after $720 \mathrm{~h}$, dark, $\mathrm{RH}=40 \%$ & Bi et al. (2016) \\
\hline Lewis base & Caffeine & $\mathrm{FTO} / \mathrm{c}-\mathrm{TiO}_{2} / \mathrm{MAPbl}_{3} /$ spiro-OMeTAD/MoO $3 / \mathrm{Ag}$ & 20.2 & $86 \%$ after $1,300 \mathrm{~h}$, dark, $85^{\circ} \mathrm{C}$ & $\begin{array}{l}\text { Wang et al. } \\
(2019 c)\end{array}$ \\
\hline Lewis base & PAGG & ITO/SnO $2 / \mathrm{FA}_{1-x} \mathrm{MA}_{x} \mathrm{Pbl}_{3} /$ Spiro-OMeTAD/Ag & 24.9 & $\begin{array}{l}85.7 \% \text { after } 504 \mathrm{~h} \text { continuous illumination; } \\
91.8 \% \text { after } 2,208 \mathrm{~h} \text { of shelf storage in dark }\end{array}$ & Ren et al. (2020) \\
\hline Lewis base & EVA & ITO/PEDOT:PSS/FASnl 3 /PCBM/BCP/Ag & 7.8 & $62 \%$ after $48 \mathrm{~h}$ in air, $\mathrm{RH}=60 \%$ & Jiang et al. (2020) \\
\hline Lewis base & Thiourea & $\mathrm{FTO} / \mathrm{C}-\mathrm{TiO}_{2} / \mathrm{MAPbl}_{3} /$ spiro-OMeTAD/Au & 19.8 & $75 \%$ after $720 \mathrm{~h}$ under dark, $\mathrm{RH}=10-20 \%$ & $\begin{array}{l}\text { Wang et al. } \\
(2018 b)\end{array}$ \\
\hline Lewis base & ITIC-Th & $\begin{array}{l}\mathrm{FTO} / \mathrm{C}-\mathrm{TiO}_{2} / \mathrm{MA}_{0.17} \mathrm{FA}_{0.83} \mathrm{~Pb}\left(\mathrm{I}_{0.83} \mathrm{Br}_{0.17}\right)_{3} / \text { spiro- } \\
\text { OMeTAD/Au }\end{array}$ & 19.2 & 95\% after $960 \mathrm{~h}$ under dark & Qin et al. (2018) \\
\hline Lewis base & Multi-ligand & $\begin{array}{l}\text { ITO/SnO } / \mathrm{FA}_{0.82} \mathrm{MA}_{0.13} \mathrm{Cs}_{0.05} \mathrm{Pbl}_{2.87} \mathrm{Br}_{0.13} / \text { Spiro- } \\
\text { OMeTAD/Au }\end{array}$ & 23.5 & $\mathrm{~N} / \mathrm{A}$ & Wu et al. (2020c) \\
\hline Lewis base & $\mathrm{WS}_{2}$ & $\begin{array}{l}\left.\text { ITO/PTAA/(Rb }{ }_{0.05} \mathrm{Cs}_{0.05} \mathrm{FA}_{0.9} \mathrm{Pbl}_{3}\right)_{0.85}\left(\mathrm{MAPbBr}_{3}\right)_{0.15} / \\
\mathrm{C}_{60} / \mathrm{ZnSe} / \mathrm{Cu}(\mathrm{Ag})\end{array}$ & 22.2 & $90 \%$ after 20 days in ambient condition & Xu et al. (2020) \\
\hline Lewis base & Poly (TA) & $\mathrm{FTO} / \mathrm{c}-\mathrm{TiO}_{2} / \mathrm{MAPbl}_{3} /$ Spiro-OMeTAD/Au & 23.5 & 92\% MPPT, 98\% dark $600 \mathrm{~h}$ & Xin et al. (2020) \\
\hline Lewis base & TPPO, TMPP & $\begin{array}{l}\text { ITO/SnO } / \mathrm{Cs}_{0.05} \mathrm{FA}_{0.8} \mathrm{MA}_{0.15} \mathrm{~Pb}\left(\mathrm{l}_{0.83} \mathrm{Br}_{0.17}\right)_{3} / \text { Spiro- } \\
\text { OMeTAD/Au }\end{array}$ & 23.4 & $80 \%$ for 14 days in dark & $\begin{array}{l}\text { Yang et al. } \\
\text { (2020b) }\end{array}$ \\
\hline Lewis base & TOPO & $\begin{array}{l}\mathrm{FTO} / \mathrm{c}-\mathrm{TiO}_{2} / \mathrm{m}-\mathrm{TiO}_{2} / \mathrm{Cs}_{0.05} \mathrm{FA}_{0.79} \mathrm{MA}_{0.16} \mathrm{~Pb}\left(\mathrm{l}_{0.83} \mathrm{Br}_{0.17}\right)_{3} / \\
\text { Spiro-OMeTAD/Au }\end{array}$ & 22.1 & $85 \%$ after 2000 h, dark, $\mathrm{RH}=50 \%$ & Ji et al. (2020) \\
\hline Lewis base & TBPO & $\begin{array}{l}\mathrm{FTO} / \mathrm{C}-\mathrm{TiO}_{2} / \mathrm{PCBA} /\left(\mathrm{FAPb}_{3}\right)_{0.87}\left(\mathrm{MAPbBr}_{3}\right)_{0.13} / \text { Spiro- } \\
\text { OMeTAD/Au }\end{array}$ & 23.9 & $92 \%$ after $250 \mathrm{~h}$ MPPT & $\begin{array}{l}\text { Wang et al. } \\
\text { (2020d) }\end{array}$ \\
\hline Lewis base & $\begin{array}{l}\text { 1,3-Diamino } \\
\text { propane }\end{array}$ & ITO/PTAA/MAPb| ${ }_{3} / \mathrm{C}_{60} / \mathrm{BCP} / \mathrm{Cu}$ & 22.6 & $\begin{array}{l}90 \% \text { after } 500 \text { h of continuous operation } \\
\text { at MPP }\end{array}$ & Wu et al. (2019b) \\
\hline Lewis base & Crown ether & $\begin{array}{l}\mathrm{FTO} / \mathrm{C}-\mathrm{TiO}_{2} / \mathrm{m}-\mathrm{TiO}_{2} / \mathrm{FA}_{0.97} \mathrm{MA}_{0.03} \mathrm{Pbl}_{2.97} \mathrm{Br}_{0.03} / \text { spiro- } \\
\text { OMeTAD/Au }\end{array}$ & 23.7 & $\begin{array}{l}80 \% \text { after } 300 \text { h of continuous operation } \\
\text { at MPP }\end{array}$ & Su et al. (2020) \\
\hline Ionic liquid & FIm & $\begin{array}{l}\mathrm{FTO} / \mathrm{c}-\mathrm{TiO}_{2} / \mathrm{m}_{-} \mathrm{TiO}_{2} / \\
\left(\mathrm{FA}_{0.85} \mathrm{MA}_{0.15}\right)_{0.95} \mathrm{Cs}_{0.05} \mathrm{~Pb}\left(\mathrm{l}_{0.9} \mathrm{Br}_{0.1}\right)_{3} / \text { spiro- } \\
\text { OMeTAD/Au }\end{array}$ & 16.3 & Same after 3,600 h under dark, $\mathrm{RH}=60 \%$ & $\begin{array}{l}\text { Salado et al. } \\
(2017)\end{array}$ \\
\hline IL & $\mathrm{BMIMBF}_{4}$ & $\begin{array}{l}\mathrm{FTO} / \mathrm{NiO}_{\times} /\left(\mathrm{FA}_{0.83} \mathrm{MA}_{0.17}\right)_{0.95} \mathrm{Cs}_{0.05} \mathrm{~Pb}\left(\mathrm{I}_{0.9} \mathrm{Br}_{0.1}\right)_{3} / \mathrm{PCBM} / \\
\mathrm{BCP} / \mathrm{Au}\end{array}$ & 20 & $\begin{array}{l}95 \% \text { after } 1800 \mathrm{~h} \text { at } 70-75^{\circ} \mathrm{C} \text { under } \\
\text { continuous illumination }\end{array}$ & Bai et al. (2019) \\
\hline IL & ETI & $\mathrm{FTO} / \mathrm{c}-\mathrm{TiO}_{2} / \mathrm{m}-\mathrm{TiO}_{2} / \mathrm{MAPbl}_{3} /$ spiro-OMeTAD/Au & 19.5 & $\begin{array}{l}83 \% \text { after } 700 \mathrm{~h} \text { at } 60^{\circ} \mathrm{C} \text { under continuous } \\
\text { illumination }\end{array}$ & Xia et al. (2019) \\
\hline
\end{tabular}


TABLE 4 | (Continued) Additive engineering on PSCs. Representative additives with the performance in PSCs.

\begin{tabular}{|c|c|c|c|c|c|}
\hline Type & Additive & Device configuration & $\begin{array}{l}\text { PCE } \\
(\%)\end{array}$ & Stability & References \\
\hline IL & Poly-RTMS & $\mathrm{FTO} / \mathrm{SnO}_{2} / \mathrm{FA}_{0.75} \mathrm{MA}_{0.25} \mathrm{Pbl}_{2.5} \mathrm{Br}_{0.5} /$ Spiro-OMeTAD/Au & 20.3 & $97 \%$ after $360 \mathrm{~h}$ under dark & $\begin{array}{l}\text { Wang et al. } \\
(2020 \text { e) }\end{array}$ \\
\hline $\begin{array}{l}\text { Surface } \\
\text { modifier }\end{array}$ & PDMAl & ITO/SnO 2 /perovskite/Spiro-OMeTAD/Au & 21 & Stable at MPP and ambient condition for $200 \mathrm{~s}$ & Hou et al. (2020b) \\
\hline $\begin{array}{l}\text { Surface } \\
\text { modifier }\end{array}$ & HPNE & $\mathrm{FTO} / \mathrm{TiO}_{2} / \mathrm{FA}_{0.91} \mathrm{Cs}_{0.09} \mathrm{Pbl}_{3} /$ spiro-OMeTAD/Au & 22.5 & $\begin{array}{l}\text { Stable at MPP and ambient condition for } \\
3,200 \mathrm{~s}\end{array}$ & Du et al. (2020) \\
\hline
\end{tabular}

Another stable device is reported with $2 \mathrm{D}$ perovskite $\mathrm{ODAPbI}_{4}$, with octyldiammonium ion (Jiang et al., 2020). The PSC shows PCE of $21.6 \%$ and high stability under a constant relative humidity of $85 \%$ and ambient temperature. Insightful reviews are available on $2 \mathrm{D}$ perovskite-based PSCs and even only focused on RP or DJ-based 2D perovskite. Those can be helpful for readers to study a wide range of examples (Gao et al., 2018; Liang et al., 2018; Huang et al., 2019b; Zhang et al., 2020; Li et al., 2021a; Liu et al., 2021b).

The linear thermal expansion coefficient of perovskite is higher $\left(\sim 45 \times 10^{-6 \circ} \mathrm{C}^{-1}\right)$ than that of the glass substrate $(10 \times$ $\left.10^{-6 \circ} \mathrm{C}^{-1}\right)$. Most of the perovskite films for PSCs are deposited at elevated temperature and when the films are cooled to room temperature, the perovskite contracts more than that of the substrate. This causes tensile stress in perovskite film which leads to instability (Ramirez et al., 2018). Various steps have been taken to improve stability under thermally induced mechanical stress and to resist fracture of the perovskite film, like X-site engineering. This topic is discussed in detail in some recent reviews (Boyd et al., 2019; Li et al., 2020b).

\section{Additive Engineering}

Other than the necessary or basic components to make a working PSC, other materials can be added to a certain part to improve the efficiency and stability (Ghosh and Singh, 2019; Wang et al., 2020b). A wide array of materials has been utilized and many of them have been proven to be beneficial. These are called additives which is kind of an umbrella term encompassing a huge matrix of materials with different functionalities. The additives can be categorized into two parts as per their time of addition during the fabrication of the PSC: 1) Additives used with precursors. 2) Posttreatment additives. The category 1 , additives that are added during the perovskite formation, those can be added with different precursors like, 1) additive added with the perovskite precursor of the one-step method, 2) the additive added with the organic solvent of the two-step perovskite formation, 3) the additive is added with the antisolvent. The additive engineering is a huge field of research and insightful reviews solely on PSC additives are available (Peng et al., 2020; Ren et al., 2020). Some examples of additives that substantially influence PSCs are discussed in this section. There are some additives that are beyond classification or multifunctional. Liu et al used a molecule 2,2-difluoropropanediamide (DFPDA), as predicted from theoretical calculations for passivation of defects (Cai et al., 2021). It is noticed that the carbonyl group can tightly bind with the $\mathrm{Pb}^{2+}$, thus restricting the movement of ions. This additive is found to be multifunctional and can "ameliorate" all the instability issues. $22.21 \%$ of PCE is reported in a n-i-p device with considerable stability. Representative additive species are summarized in Table 4 including the device configuration, stability, and PCE.

\section{Lewis Acids}

A Lewis acid can accept a lone pair of nonbonding electron, and thus can passivate electron-rich defects (Lee et al., 2016). The added Lewis acid species can form a Lewis adduct with any under-coordinated halides and $\mathrm{PbX}_{3}{ }^{-}$via ionic or coordinate bonding. Restricting these species via strong bonding can eliminate the corresponding defects or traps that are responsible for nonradiative recombination. Positively charged metal cations are proven to be effective in passivation. Two groups have demonstrated that a little excess of $\mathrm{PbI}_{2}$ can effectively passivate the perovskite film (Shi et al., 2018; Yang et al., 2020a). That leads to longer carrier lifetime and reduced halide vacancies for high-efficiency perovskite solar cells. Randomly distributed $\mathrm{PbI}_{2}$ may have detrimental effects (Tumen-Ulzii et al., 2020). Ordering can be achieved by ligand modulation. 22\% PCE could be achieved over 20\% PCE of the control device and $72 \%$ of the initial efficiency is retained after $360 \mathrm{~h}$ constant illumination at maximum power point (Yang et al., 2020b). $\mathrm{CdI}_{2}$ treatment significantly reduces interfacial charge recombination loss via strong Cd-I bonds which reduces I-vacancy at the surface. $21.9 \%$ of PCE was achieved with voltage deficit of only $0.31 \mathrm{~V}$ than the theoretical value. $92 \%$ of initial efficiency is retained after constant illumination at 1 Sun intensity for $1,000 \mathrm{~h}$ (Wu et al., 2020b). Group 1 cations, $\mathrm{Li}^{+}, \mathrm{Na}^{+}, \mathrm{K}^{+}$are proven to be effective in passivation which can change the lattice constants of the perovskite crystal, while bigger size $\mathrm{Cs}^{+}$and $\mathrm{Rb}^{+}$cannot change the lattice constants (Li et al., 2020c). $\mathrm{Li}^{+}$and $\mathrm{Na}^{+}$can be diffused from the HTL and the source respectively (Bi et al., 2017; Li et al., 2017; Abdi-Jalebi et al., 2018a).

Several reports are available on the improvement of PCE and stability upon the addition of KI (Kubicki et al., 2017; Abdi-Jalebi et al., 2018a; Cao et al., 2018). $\mathrm{K}^{+}$can passivate following the way mentioned before while $\mathrm{I}^{-}$can fill up the iodide vacancies of perovskite. $\mathrm{NaF}$ is also found to be effective in the same way. Other metal cations such as $\mathrm{Zn}^{2+}, \mathrm{Mg}^{2+}, \mathrm{Ni}^{2+}$, and $\mathrm{Eu}^{3+}-\mathrm{Eu}^{2+}$ are also proven to be effective and provided PSCs with high stabilities (Saliba et al., 2016b; Poindexter et al., 2017; Abdi-Jalebi et al., 2018b; Gong et al., 2018; Wang et al., 2019b; Kooijman et al., 2019). 
Several organic molecules are also found to be useful as additive Lewis acids for PSCs (Yang et al., 2020b; Luo et al., 2020; Peng et al., 2020). Fullerene derivatives are very suitable for this due to their high electron affinity. Many of them have multiple utilities. They can passivate the trap states by receiving electrons on one hand and also they can cover the grain boundaries on the other hand, thus restricting the movement of mobile ions along grain boundaries by creating steric hindrance (Shao et al., 2014; Xu et al., 2015; Saliba et al., 2016b; Chiang and Wu, 2016; Poindexter et al., 2017; Abdi-Jalebi et al., 2018b; Gong et al., 2018; Wang et al., 2019b; Kooijman et al., 2019). The $\mathrm{C}_{60}$ and $\mathrm{C}_{60}$ derivatives have shown limited performance in enhancing the PCEs and $80-85 \%$ of efficiency could be retained over long exposure, as found in early studies. Phenyl- $\mathrm{C}_{61}$-butyric acid methyl ester (PCBM) and its derivatives are also proven to be beneficial. $\alpha$-bis PCBM used as an additive and $20.8 \%$ efficiency could be achieved in a mesoporous $\mathrm{TiO}_{2}-$ based device (Zhang et al., 2017). 96\% of the initial efficiency is retained after $600 \mathrm{~h}$ of continuous exposure.

\section{Lewis Bases}

A Lewis base contains an electron-rich moiety with a lone pair of electron which can easily be donated to a suitable species (Lee et al., 2016). In case of perovskites, a Lewis base can bond with the $\mathrm{Pb}^{2+}$ cation and thus passivate defects (Yang et al., 2018b). As an electron-rich moiety is required, the Lewis base is usually an organic molecule with $\mathrm{N}, \mathrm{O}$, or $\mathrm{S}$ as the electron donor site.

$\mathrm{N}$-donor Lewis bases generally contain pyridine or primary amino group which have a lone pair of electron on $\mathrm{N}$, which can be readily donated. Addition of pyridine improves the film quality, passivates the surface defects, and the PCE is increased to $19 \%$ from $16.9 \%$ (Wu et al., 2018). The improvement of film quality is caused by the pyridine that made the film formation slower. Long-chain polymers with pyridine or primary amino group can passivate the defects effectively and deliver an efficient and stable device. $\left(-\mathrm{NH}_{2}\right)$ tails can bond with $\mathrm{Pb}^{2+}$ to facilitate defect passivation and they also can fill in A-site vacancies (Zhou et al., 2019c; Wu et al., 2020b). Amine-based Lewis base additive results in highly stable PSCs that can retain $95 \%$ of the initial efficiency under humid condition at room temperature (Guo et al., 2019). Small molecules such as urea, caffeine have proven to be effective. Those can retard the perovskite film formation and high efficiency and stability can be achieved by successful defect passivation. Particularly, caffeine can make a strong bonding with $\mathrm{PbI}_{2}$, $20.25 \%$ of efficiency can be achieved with thermal stability at $85^{\circ} \mathrm{C}, 1,300 \mathrm{~h}$ (Wang et al., 2019c; Wang et al., 2019e). N-based Lewis bases theophylline and theobromine have also been proven to enhance efficiency and stability (Wang et al., 2019e).

Commonly used solvents such as DMF, DMSO can interact with the perovskite by the lone pair of oxygen on $\mathrm{O}$ (Lee et al., 2014b; Jeon et al., 2014). Poly (methyl methacrylate) PMMA can enable heterogeneous nucleation when added with the antisolvent (Bi et al., 2016). It promotes heterogeneous nucleation by making an adduct with $\mathrm{PbI}_{2}$, which causes random formation of nuclei. This minimizes the Gibbs free energy of formation and the crystal can grow in thermodynamically preferred orientation. These pave the way for the formation of smooth perovskite film with fewer defects and a satisfactory efficiency of $21 \%$ is achieved. Polymeric species with $\mathrm{C}=\mathrm{O}$ group has proven to be effective in passivating the defects in the perovskite, hence stabilizing the devices (Chang and Wang, 2020; Jiang et al., 2020; Ren et al., 2020).

S-donor Lewis bases are more effective in electron donation than their O-counterparts. Several S-based organic molecules such as thiourea, thiophene, and their derivatives are proven to be able to make strong bonds with under-coordinated $\mathrm{Pb}^{2+}$ (Lee et al., 2017; Guo et al., 2019). Organic molecule with both $\mathrm{N}$ and $\mathrm{S}$ donor sites, a thiadiazole derivative, is proven to be very effective in stabilizing the perovskite film. 19.04\% of efficiency was achieved with good stability under heat and humidity (Zhu et al., 2018b). Zhang et al reported simultaneous usage of S-donor Lewis base and a PCBM derivative Lewis acid (Zhang et al., 2018b). The Lewis acid and Lewis base synergistically passivate $\mathrm{PbX}_{3}{ }^{-}$and $\mathrm{Pb}^{2+}$ antisite defects and the charge-carrier separation is improved. $21.7 \%$ efficiency was achieved over $19.3 \%$ efficiency of the control device. Significant stability is achieved, 93\% of PCE is retained under ambient condition over 3,600 h. Multi-ligandbased pentaerythritol tetrakis (3-mercaptopropionate) is effective in suppressing $\mathrm{Pb}^{2+}$ and $\mathrm{Pb}^{0}$ defects (Wu et al., 2020c). S-moiety in $\mathrm{WS}_{2}$ has also proven to be effective (Xu et al., 2020). Poly (thioctic acid) is highly hydrophobic and presence of both $\mathrm{C}=\mathrm{S}$ and $\mathrm{C}=\mathrm{O}$ can effectively passivate the defects and yield a stable device (Xin et al., 2020).

Sargent et al have experimented Lewis bases with different donor moiety such as $\mathrm{C}=\mathrm{O}, \mathrm{S}=\mathrm{O}, \mathrm{As}=\mathrm{O}, \mathrm{P}=\mathrm{O}$, end groups $(\mathrm{Na}$ Quan et al., 2020). The dative bond of $\mathrm{P}=\mathrm{O}: \mathrm{Pb}$ has the strongest binding energy. So, P-based Lewis bases are proposed to be very promising in passivating defects in perovskite. Several P-based species are reported with satisfactory efficiency and stability (Yang et al., 2020b; Wang et al., 2020d; Ji et al., 2020).

Zwitterionic species consisting of two functional groups can passivate both positively charged and negatively charged defects simultaneously. A few reports of successful implementations of Zwitterions to enhance PSC efficiency and stability are available (Zheng et al., 2019a; Zhou et al., 2019d). Graetzel et al recently employed a crown ether compound to modify the perovskite film (Su et al., 2020). It acts as a host in host-guest complexes on the perovskite surface, which significantly reduces surface electronic defects. Non-radiative recombination is suppressed by $40 \%$ and moisture permeation is also greatly reduced. More than $23 \%$ of PCE is achieved with significant stability in ambient and operational conditions.

\section{Ionic Liquids}

Ionic liquids (IL) are salts consisting of a large organic cation and small or large, inorganic or organic anion. Owing to the larger sizes, the interionic space is more and the electrostatic forces between them are lower. So, the salts become liquids below $100^{\circ} \mathrm{C}$, often at room temperature. ILs are not volatile and not flammable. ILs have high ionic conductivity, electrochemical stability and can dissolve various ionic and covalent compounds (Ghosh and Singh, 2019; MacFarlane et al., 2016; 


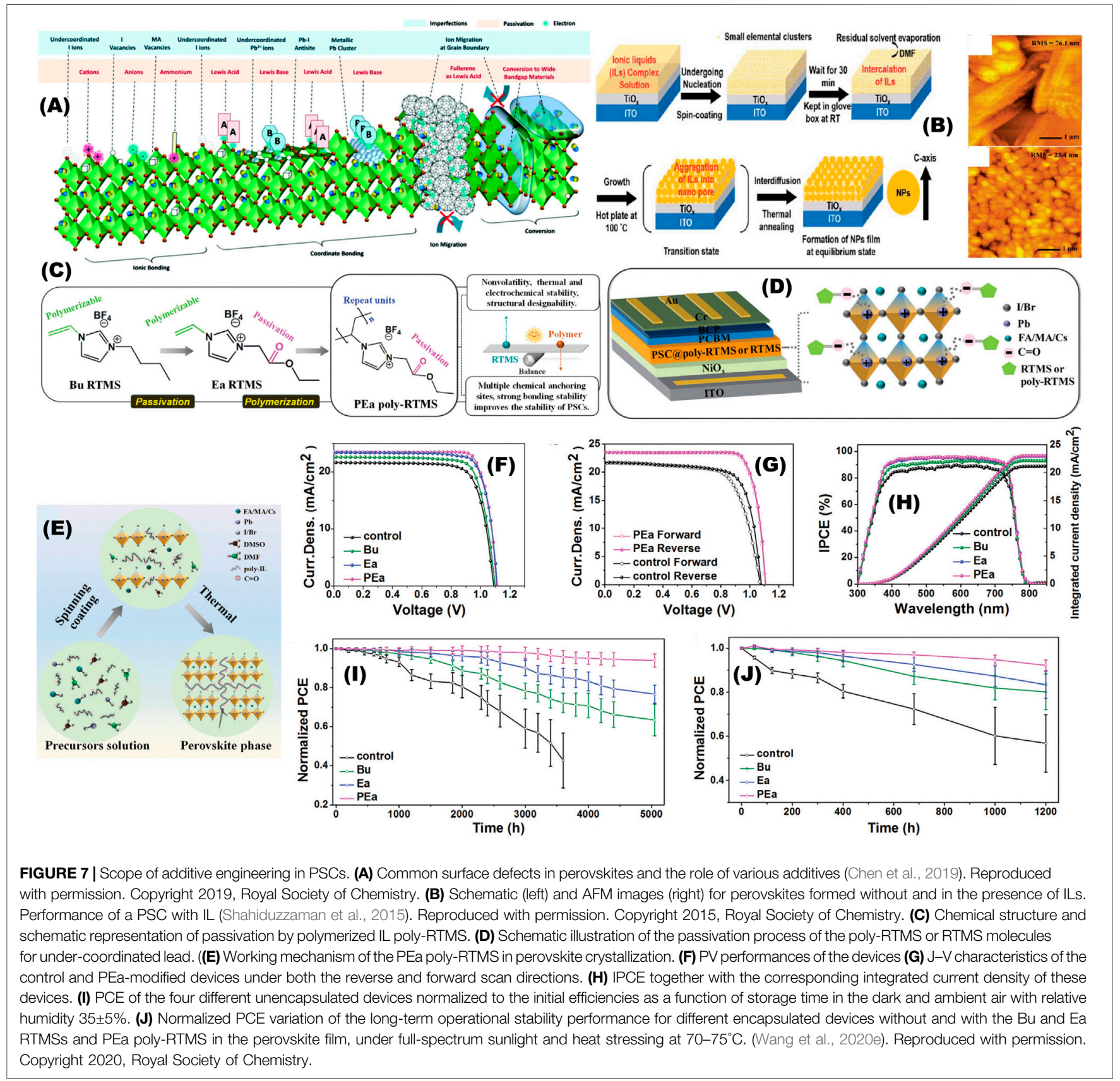

Rogers and Seddon, 2003; Welton, 1999). Certain ILs are hydrophobic in nature. ILs can improve the PSC by various ways. Imidazolium-based ILs are proven to be effective in forming high-quality perovskite film by uniform nucleation and preventing rapid crystallization (Shahiduzzaman et al., 2015) (Figure 7B). The film quality can be tuned by varying the viscosity of the IL (Shahiduzzaman et al., 2017). Imidazoliumbased ILs have also shown excellent hydrophobic property (Salado et al., 2016). The PCE has been improved up to 20 days of storage due to continuing evaporation of the ILs. These devices are stable up to 90 days (Saliba et al., 2016a; Singh and Miyasaka, 2018). A fluorous-functionalized imidazolium- based ionic salt (FIm) and an ionic salt 1-(4-ethenylbenzyl)-3$(3,3,4,4,5,5,6,6,7,7,8,8,8$-tridecafluorooctylimidazolium iodide (ETI) have been proven to be useful in enhancing thermal and atmospheric stability of the PSCs (Salado et al., 2017; Xia et al., 2019). Triazolium-based ILs have strong hydrophobicity due to the formation of self-assembly (Wang et al., 2019f). The amine group bonded with $\mathrm{Pb}^{2+}$ to passivate the defects, thus an efficient and stable device is formed. Zhou et al reported an amino group functionalized imidazolium-based IL with strong hydrophobicity (Zhou et al., 2019c). It makes H-bonding with the iodide. The film formation is retarded and a high-quality crystalline film is formed. The H-bonding restricts the iodide ion, which boosts 
the stability. Moreover, the hydrophobic nature highly helped in stability. An efficient device is formed which can retain $94 \%$ of the initial PCE after $840 \mathrm{~h}$ of device. Imidazolium-based ILs are widely used and demonstrated good moisture and thermal stability. They are proven to be also capable of restricting the movement of A-site cation (Wang et al., 2019g). ILs are not only capable of modifying the perovskite film but they are also useful in interface modification. The oxide charge-transporting layer often suffers from defects, nonuniformity, and high roughness. An IL can modify the interface between the oxide film and the perovskite (Wojciechowski et al., 2014). Improved crystallinity of the perovskite film is observed. Yang et al successfully modify a mesoporous titania surface with an imidazolinium-based IL (Yang et al., 2016). The roughness of the oxide film reduces significantly and $19.62 \%$ PCE is achieved with good stability. The IL also increases the electron mobility of the ETL and reduces trap-state density by restricting ion migration in perovskite. Piperazinium iodide containing both $\mathrm{R}_{2} \mathrm{NH}$ and $\mathrm{R}_{2} \mathrm{NH}_{2}{ }^{+}$ groups on the same six-membered ring acts as both an electron donor and an electron acceptor to react with different surface-terminating ends on perovskite films. This is highly effective in suppressing non-radiative recombination losses and in passivating defects, results in PCE of $23.37 \%$, one of the highest in inverted devices (Ji et al., 2020).

Snaith et al reported efficient and highly stable PSCs with p-i-n architecture. The exceptional stabilities are achieved by an imidazolium-based IL and a piperidinium-based salt. ILs with bigger anionic groups are also reported and it is observed that the cationic part of the IL directs the modification property to the perovskite (Bai et al., 2019). A series of water-soluble triazolium ILs are used in $\mathrm{MAPbI}_{3}$-based PSCs, more than $20 \%$ of efficiency is reported with good stability (Wang et al., 2019f). Hagfeldt et al used a polymeric molten salt poly (1-vinyl-3-ethyl-acetate) imidazole tetrafluoroborate as an additive (Wang et al., 2020e). It has various anchoring sites that can bond with $\mathrm{Pb}^{2+}$ defects at grain boundaries and the interface of the perovskite film by forming a coordination bond. That could efficiently passivate the defects and boost the photo-, thermal-, and moisture stability of perovskite films. 21.4\% PCE is achieved in the p-i-n device and more than $92 \%$ of the initial efficiency is retained after $1,200 \mathrm{~h}$ under continuous full Sun illumination at $70-75^{\circ} \mathrm{C}$ (Figures 7C-J). Protic amine carboxylic acid ILs are environmentfriendly and bifunctional; they can bond strongly with the perovskite by forming $\mathrm{C}=\mathrm{O} \ldots \mathrm{Pb}$ chelate bonds and $\mathrm{N}-\mathrm{H}$...I hydrogen bonds and high-efficiency, high-stability devices could be achieved (Chao et al., 2020). Various surface defects in perovskites and how different additive engineering strategies can be used to passivate them are described by a schematic in Figure 7A.

\section{Surface Modifier}

In the previous section, we have discussed that ILs can be used to modify the interfaces. Other compounds also can be used to modify the surface of charge-transporting layer and the perovskite. $\mathrm{TiO}_{2}$ ETL are prone to UV degradation. Various fullerene-based molecules such as $\mathrm{C}_{60}$-SAM (self-assembled monolayer), PCBM, and their derivatives are used to improve the UV-stability of titania films (Abrusci et al., 2013; Wojciechowski et al., 2014; Chen et al., 2016). Many fullerene derivatives are successful to increase the open circuit voltage by surface modification. Various ILs are proven to be effective surface modifier of ETL oxides. Several approaches are also taken to modify the HTL surface. $\mathrm{V}_{2} \mathrm{O}_{5}$ is used to replace LiTFSI with Spiro HTL and an efficiency of $20.1 \%$ is achieved (Wang et al., 2019h). $\mathrm{V}_{2} \mathrm{O}_{5}$ is also proven to be beneficial for efficiency and stability while being used with PEDOT:PSS. Perovskite films are also modified by several species and dopant. Several Cs-based perovskite quantum dots (QDs) are used to modify the perovskite (Liu et al., 2018a; Zheng et al., 2019b). The QDs can improve the optoelectronic properties and charge separation. Other inorganic salts $\mathrm{PbSO}_{4}, \mathrm{~Pb}_{3}\left(\mathrm{PO}_{4}\right)_{2}$ are used to enhance water resistance (Yang et al., 2019). Luminescent perovskite nanoparticles are stabilized by crosslinking and high photoluminescence quantum yield could be retained even after one and half years of storage (Jang et al., 2021b). A novel molecule: p-phenyl dimethylammonium iodide (PDMAI) with ammonium group on both terminals as the modifier of the perovskite layer is also proven to be an effective passivation material (Qi et al., 2020). The hydrophobicity induced by alkyl and aryl tail gives environmental stability. In another report, we introduced a thin layer of poly (triaryl amine) on the top of the perovskite film before annealing (Hou et al., 2019b). It causes a smooth and compact perovskite film with passivated surface defects and grain boundaries. The modified film shows faster charge transfer capability and longer lifetime. The hydrophobic polymer on the top of the perovskite induces stability. The PSC with modified film have $17.77 \%$ PCE compared to $16.15 \%$ of the control device. The modified device retained $83 \%$ of initial PCE under ambient condition over one month, while the control PSC only can retain $56 \%$ of the initial PCE. A high-pressure nitrogenextraction strategy is used during a Slot-die coating of perovskite on a large area substrate. $19.4 \%$ of PCE is achieved for a $40 \times$ $40 \mathrm{~mm}^{2}$ module, which is highest on a large-area module ( $\mathrm{Du}$ et al., 2020). We introduced a cross-linking agent aluminum acetylacetonate $\left[\mathrm{Al}(\mathrm{acac})_{3}\right]$ as an interface layer between ETL and the perovskite. Well-matched energy levels and improved grain size and crystallinity of the perovskite helped in achieving $20.87 \%$ PCE in a flexible PSC. The devices have manifested outstanding moisture stability and bending resistance (Ren et al., 2021).

\section{To Prevent Electrode-Induced Degradation}

Degradation mechanisms induced by metal electrodes at the dark side are discussed in detail in Interaction With Electrodes and Degradation at Interfaces. Some strategies to avoid electrodeinduced degradation are discussed here. Either an alternative electrode can be employed or an additional barrier layer can be introduced to prevent degradation due to metallic electrodes (Xie et al., 2017). Carbon-based materials are presented to be most suitable candidate to replace the metal electrodes (Habisreutinger et al., 2014; Gholipour et al., 2016; Aitola et al., 2017; Grancini et al., 2017; Wang et al., 2020a). Some C-structures also can be simultaneously used as the charge-transporting layer (Wang et al., 2020a). Carbon nanostructures with mesoporous oxides like titania have been reported to give stable devices 
TABLE 5 | Encapsulation of PSCs. Example of various representative encapsulants and the degradation of PCE after testing.

\begin{tabular}{|c|c|c|c|c|}
\hline Encapsulant & Thickness & Stability test & Degradation (\%) & References \\
\hline Teflon & $\mathrm{N} / \mathrm{A}$ & $168 \mathrm{~h}, \mathrm{RH}=50 \%$ & 9 & Hwang et al. (2015) \\
\hline Paraffin & & $1,000 \mathrm{~h}, \mathrm{RH}=30-50 \%$ & 20 & Ma et al. (2020b) \\
\hline Adamantine nanocomposite & $200 \mathrm{~nm}$ & $216 \mathrm{~h}, \mathrm{RH}=85 \%$ & 27 & Idígoras et al. (2018) \\
\hline UV curable fluoropolymer & $5 \mu \mathrm{m}$ & $\begin{array}{l}2,190 \mathrm{~h}, \text { outdoor } \\
730 \mathrm{~h}, \mathrm{RH}=95 \% \\
2,190 \mathrm{~h}, \mathrm{UV}, \mathrm{RH}=50 \%\end{array}$ & $\begin{array}{l}5 \\
5 \\
0\end{array}$ & Bella et al. (2016) \\
\hline View barrier & $240 \mu \mathrm{m}$ & $500 \mathrm{~h}, \mathrm{RH}=30-80 \%$ & 0 & Weerasinghe et al. (2015) \\
\hline $\mathrm{Al}_{2} \mathrm{O}_{3} / \mathrm{pv} 3 \mathrm{D} 3$ & 800 nm & 300 h, $50{ }^{\circ} \mathrm{C}, \mathrm{RH}=50 \%$ & 3 & Lee et al. (2018b) \\
\hline Cross-linked grain encapsulation & $\mathrm{N} / \mathrm{A}$ & $10,000 \mathrm{~h}$, ambient & 10 & Xiao et al. (2021) \\
\hline Organosilicate & $200 \mathrm{~nm}$ & $\begin{array}{l}150 \mathrm{~h}, 85^{\circ} \mathrm{C}, \mathrm{RH}=85 \% \\
3,176 \mathrm{~h}, 85^{\circ} \mathrm{C}, \mathrm{RH}=25 \%\end{array}$ & $\begin{array}{c}45 \\
8\end{array}$ & Rolston et al. (2017) \\
\hline
\end{tabular}

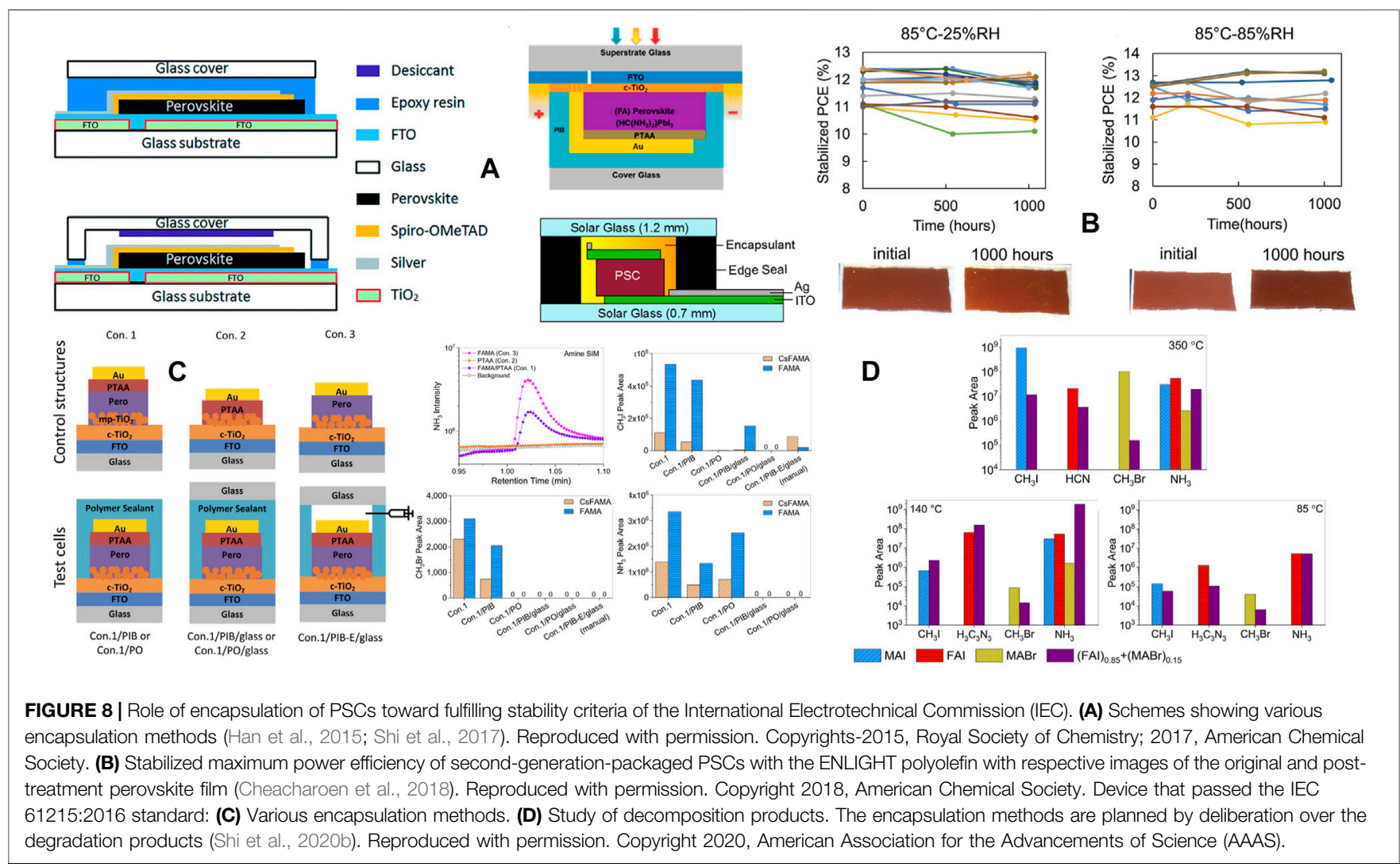

(Habisreutinger et al., 2014; Gholipour et al., 2016; Aitola et al., 2017; Grancini et al., 2017; Huang et al., 2018; Tian et al., 2018). Another alternative is transparent conductive oxides such as ITO or $\mathrm{MoO}_{3}$ (Bush et al., 2016). Graphene-based electrodes have also been utilized to stabilize organic photovoltaic devices (Walsh et al., 2021). Those can produce stable devices but, whether conducting oxides or Carbon-based materials, the conductivities are much lower than that of metals. So, adding a metal contact on the top of the electrode can enhance the efficiency.

An effective barrier layer in between the metal electrode and the charge-transporting layer can prevent the metal and the halogen species from the perovskite to come in contact with each other. C-based materials and ITO have been used as the interface layer. Other than that, various oxides and organic molecules have been utilized such as $\mathrm{Cu}$ 
TABLE 6 | Reliability and stability of PSC. Various examples of PSCs that passed the IEC 61215:2016 or the IEC 61646 test.

\begin{tabular}{|c|c|c|c|c|c|}
\hline Test & Perovskite & Conditions & Lifetime & Remarks & References \\
\hline Damp heat & $\mathrm{FA}_{1-x} \mathrm{Cs}_{x} \mathrm{Pbl}_{3-\mathrm{y}} \mathrm{Br}_{\mathrm{y}}$ & $85^{\circ} \mathrm{C}, \mathrm{RH}=85 \%$ & $\begin{array}{l}\text { 1,000 h with no } \\
\text { decay }\end{array}$ & $\begin{array}{l}\text { An inverted device in } \\
\text { tandem with a Si solar cell }\end{array}$ & Bush et al. (2017) \\
\hline $\begin{array}{l}\text { Thermal } \\
\text { cycle }\end{array}$ & $\mathrm{FAPbl}_{3}$ & $\begin{array}{l}-40-85^{\circ} \mathrm{C} \text {, dwell at }-40 \text { and } 85^{\circ} \mathrm{C} \text { for } \\
15 \text { min each }\end{array}$ & $\begin{array}{l}200 \text { thermal cycles } \\
\text { with no decay }\end{array}$ & $\begin{array}{l}\text { Encapsulation by } \\
\text { polyisobutylene }\end{array}$ & Shi et al. (2017) \\
\hline $\begin{array}{l}\text { Outdoor } \\
\text { condition }\end{array}$ & $\mathrm{FA}_{1-x} \mathrm{MA}_{x} \mathrm{Pbl}_{3-\mathrm{y}} \mathrm{Br}_{\mathrm{y}}$ & Roof top & $\begin{array}{l}\text { 95\% PCE retained } \\
\text { after } 3 \text { months }\end{array}$ & $\begin{array}{l}\text { Encapsulation by } \\
\text { photocurable } \\
\text { fluoropolymers }\end{array}$ & Bella et al. (2016) \\
\hline $\begin{array}{l}\text { UV } \\
\text { irradiation }\end{array}$ & $\mathrm{FA}_{1-x} \mathrm{MA}_{x} \mathrm{Pbl}_{3-\mathrm{y}} \mathrm{Br}_{\mathrm{y}}$ & UV irradiation in $\mathrm{Ar}$ and air $(\mathrm{RH}=50 \%)$ & $\begin{array}{l}98 \% \text { PCE } \\
\text { retention after } \\
6 \text { months }\end{array}$ & $\begin{array}{l}\text { Encapsulation by } \\
\text { photocurable } \\
\text { fluoropolymers }\end{array}$ & Bella et al. (2016) \\
\hline Damp heat & $\mathrm{FAPbl}_{3-x} \mathrm{Br}_{x}$ & $85^{\circ} \mathrm{C}, \mathrm{RH}=85 \%$, light soaking at 1 sun & $\begin{array}{l}\sim 95 \% \mathrm{PCE} \\
\text { retained after } \\
1,000 \mathrm{~h}\end{array}$ & $\begin{array}{l}\text { Lamination by conductive } \\
\text { polymer }\end{array}$ & Heo et al. (2019) \\
\hline Damp heat & $(5-\mathrm{AVA})_{0.05}(\mathrm{MA})_{0.95} \mathrm{Pbl}_{3}$ & $85^{\circ} \mathrm{C}, \mathrm{RH}=85 \%$ & $\begin{array}{l}\text { Negligible decay } \\
\text { after } 500 \mathrm{~h}\end{array}$ & $\begin{array}{l}\text { Laser-assisted hermetic } \\
\text { encapsulation }\end{array}$ & Emami et al. (2020) \\
\hline Damp heat & $\begin{array}{l}2 \mathrm{D}\left(\mathrm{C}_{4} \mathrm{H}_{9} \mathrm{NH}_{3}\right)_{2} \mathrm{Pbl}_{4} / 3 \mathrm{D}\left(\mathrm{FAPbl}_{3}\right)_{0.95} \\
\left(\mathrm{MAPbBr}_{3}\right)_{0.05}\end{array}$ & $\begin{array}{l}1 \text { sun illumination } \\
85^{\circ} \mathrm{C}, \mathrm{RH}=85 \%\end{array}$ & $\begin{array}{l}\text { 98\% PCE retained } \\
\text { after } 1,620 \mathrm{~h} \\
94 \% \mathrm{PCE} \text { retained } \\
\text { after } 1,056 \mathrm{~h}\end{array}$ & $\begin{array}{l}\text { Solid state in-plane growth } \\
\text { of } 2 \mathrm{D} / 3 \mathrm{D} \text { halide junction } \\
\text { perovskite }\end{array}$ & Jang et al. (2021a) \\
\hline Hail impact & $\mathrm{FA}_{0.93} \mathrm{Cs}_{0.07} \mathrm{Pbl}_{3}$ & Dropping a metal ball on the solar module & $\begin{array}{l}\text { Module did not } \\
\text { break star-shaped } \\
\text { cracks }\end{array}$ & $\begin{array}{l}\text { Self-healing polymer-based } \\
\text { encapsulation }\end{array}$ & Jiang et al. (2019) \\
\hline Damp heat & $\mathrm{Cs}_{0.05} \mathrm{FA}_{0.8} \mathrm{MA}_{0.15} \mathrm{~Pb}\left(\mathrm{l}_{0.85} \mathrm{Br}_{0.15}\right)_{3}$ & $85^{\circ} \mathrm{C}, \mathrm{RH}=85 \%$ & $\begin{array}{l}>95 \% \mathrm{PCE} \\
\text { retention after } \\
1,000 \mathrm{~h}\end{array}$ & $\begin{array}{l}\text { Pressure-tight polymer/ } \\
\text { glass stack encapsulation }\end{array}$ & Shi et al. (2020b) \\
\hline $\begin{array}{l}\text { Thermal } \\
\text { cycling }\end{array}$ & & $\begin{array}{l}-40-85^{\circ} \mathrm{C} \text {, dwell at }-40 \text { and } 85^{\circ} \mathrm{C} \text { for } \\
15 \text { min each, ramp rate }=100^{\circ} \mathrm{C} / \mathrm{h}\end{array}$ & $\begin{array}{l}>95 \% \text { PCE } \\
\text { retention after } 200 \\
\text { cycles }\end{array}$ & & \\
\hline $\begin{array}{l}\text { Humidity } \\
\text { freeze }\end{array}$ & & $\begin{array}{l}50 \text { rounds of thermal cycling as } \\
\text { prerequisite, followed by }-40^{\circ} \mathrm{C}(30 \mathrm{~min} \\
\text { dwell) to } 85^{\circ} \mathrm{C}, 85 \% \mathrm{RH}(20 \mathrm{~h} \text { dwell). } \\
\text { Ramp rate of } 100^{\circ} \mathrm{C} / \mathrm{h} \text { for } 0^{\circ} \mathrm{C} \leftrightarrow 85^{\circ} \mathrm{C} \text {. } \\
\text { Ramp rate of } 200^{\circ} \mathrm{C} / \mathrm{h} \text { for } 0^{\circ} \mathrm{C} \leftrightarrow-40^{\circ} \mathrm{C}\end{array}$ & $\begin{array}{l}>95 \% \text { PCE } \\
\text { retention after } 10 \\
\text { cycles }\end{array}$ & & \\
\hline
\end{tabular}

phthalocyanine, $\mathrm{MoO}_{3} / \mathrm{SnO}_{2}, \quad \mathrm{MoO}_{3} / \mathrm{Al}, \mathrm{SnO}_{2}, \quad$ cross-linked polymers (Zhao et al., 2014; Beal et al., 2016; Sanehira et al., 2016). Morphology of the barrier is very important in this regard, a rough morphology can introduce channels for diffusion of halides from the perovskite and metal from electrodes, but a planar morphology can make the barrier impermeable, thus enabling a highly stable device (Boyd et al., 2018). Excellent reviews are available where measures taken to prevent electrodeinduced degradation like interface modification, C-electrode are discussed in detail and various examples are listed ( $\mathrm{Li}$ et al., 2020b; Hadadian et al., 2020).

\section{Encapsulation}

One of the most effective tools to improve the stability of PSCs is encapsulation i.e. packaging of the device with suitable materials. Encapsulation can resist external factors causing degradation of the PSCs. An effective encapsulation should resist external moisture, oxygen to reach the perovskite layer. It should stop the irreversible loss of volatile organic solvents or halides from the device and should be able to withstand mechanical stress during thermal fluctuation of the device. It should withstand external mechanical factors such as rain, snow, and hail (Wang et al., 2020a). If the encapsulation is also on the top-side, i.e., toward the light, it should be easily cleanable and should be enough transparent to allow ample amount of light to reach the actual device (Kempe, 2017). The ability of an encapsulation material can be measured by water vapor transmission rate (WVTR) (Lee et al., 2018b). Moisture instability of perovskite is detected at early stage and multilayered inorganic/ organic film with $\mathrm{Al}_{2} \mathrm{O}_{3}$ is used for encapsulation (Chang et al., 2015). Epoxy resins are widely used as an edge-sealant that is used to stick a glass on the metallic electrode (Dong et al., 2016). Surlyn encapsulant is also reported to produce a stable device ( $\mathrm{Li}$ et al., 2015). Various aspects of epoxy resin encapsulation are studied. Cross-linked grain encapsulation facilitates simultaneous enhancement of moisture tolerance and defect passivation of perovskite. $22.7 \%$ of $\mathrm{PCE}$ is achieved for $1.55 \mathrm{eV}$ bandgap perovskite and $>90 \%$ of the initial PCE can be retained for over $10,000 \mathrm{~h}$, in shelf storage under ambient condition (Xiao et al., 2021). The representative encapsulation results are listed in Table 5. Various encapsulation methods are depicted in Figure 8. 
TABLE 7 | Reliability and stability of PSCs. Typical examples of PSCs under IEC 61215:2016 or IEC 61646 test.

\begin{tabular}{|c|c|c|c|c|c|}
\hline Test & Perovskite & Conditions & Lifetime & Remarks & References \\
\hline $\begin{array}{l}\text { Damp } \\
\text { heat }\end{array}$ & $\mathrm{Cs}_{0.05}\left(\mathrm{FA}_{0.83} \mathrm{MA}_{0.17}\right)_{0.95} \mathrm{~Pb}\left(\mathrm{l}_{0.83} \mathrm{Br}_{0.17}\right)_{3}$ & $85^{\circ} \mathrm{C}, \mathrm{RH}=85 \%$ & $\begin{array}{l}80 \% \text { PCE retained } \\
\text { after } 400 \mathrm{~h}\end{array}$ & CuSCN HTL with $\mathrm{CuGaO}_{2}$ NP & Lee et al. (2019) \\
\hline $\begin{array}{l}\text { IEC } \\
61215\end{array}$ & $\mathrm{CH}_{3} \mathrm{NH}_{3} \mathrm{Pbl}_{3}$ & $85^{\circ} \mathrm{C}, \mathrm{RH}=85 \%$ & $\begin{array}{l}80 \% \text { PCE retained } \\
\text { after } 500 \mathrm{~h}\end{array}$ & $\begin{array}{l}\text { Composite encapsulation by } \mathrm{ALD}_{\mathrm{Al}_{2} \mathrm{O}_{3} \text { and }} \\
\text { hydrophobic silane }\end{array}$ & Lv et al. (2020) \\
\hline $\begin{array}{l}\text { Damp } \\
\text { heat }\end{array}$ & $\mathrm{Cs}_{0.05} \mathrm{FA}_{0.88} \mathrm{MA}_{0.07} \mathrm{Pbl}_{2.56} \mathrm{Br}_{0.44}$ & $85^{\circ} \mathrm{C}, \mathrm{RH}=85 \%$ & $\begin{array}{l}91.7 \% \text { PCE retained } \\
\text { after } 1,000 \mathrm{~h}\end{array}$ & $\begin{array}{l}\text { Polymer passivation layer engineering- } \\
\text { nanoscale localized contacts }\end{array}$ & $\begin{array}{l}\text { Peng et al. } \\
(2021)\end{array}$ \\
\hline various & $\mathrm{CH}_{3} \mathrm{NH}_{3} \mathrm{Pbl}_{3}$ & $\begin{array}{l}\text { Ambient air, } \mathrm{RH}= \\
40-70 \% \\
\text { Continuous } \\
\text { illumination at } 1 \text { sun } \\
85^{\circ} \mathrm{C}, \mathrm{RH}=85 \%\end{array}$ & $\begin{array}{l}\text { 95\% PCE retained } \\
\text { after 4,000 h } \\
\text { 95\% PCE retained } \\
\text { after 3,000 h } \\
\text { 95\% PCE retained } \\
\text { after } 168 \mathrm{~h}\end{array}$ & $\begin{array}{l}\text { DJ phase 2D layered perovskite enables } \\
\text { stability }\end{array}$ & $\begin{array}{l}\text { Ahmad et al. } \\
\text { (2019) }\end{array}$ \\
\hline $\begin{array}{l}\text { IEC } \\
61215\end{array}$ & $\mathrm{Cs}_{0.05}\left(\mathrm{MA}_{0.17} \mathrm{FA}_{0.83}\right)_{0.95} \mathrm{~Pb}\left(\mathrm{l}_{0.83} \mathrm{Br}_{0.17}\right)_{3}$ & $85^{\circ} \mathrm{C}, \mathrm{RH}=85 \%$ & $\begin{array}{l}92 \% \text { PCE retained } \\
\text { after } 1,000 \mathrm{~h}\end{array}$ & Compositional engineering of perovskite & $\begin{array}{l}\text { Matsui et al. } \\
(2019)\end{array}$ \\
\hline $\begin{array}{l}\text { IEC } \\
61646\end{array}$ & $\mathrm{Cs}_{0.05}\left(\mathrm{MA}_{0.17} \mathrm{FA}_{0.83}\right)_{0.95} \mathrm{~Pb}\left(\mathrm{l}_{0.83} \mathrm{Br}_{0.17}\right)_{3}$ & $85^{\circ} \mathrm{C}, \mathrm{RH}=85 \%$ & $\begin{array}{l}65 \% \text { PCE retained } \\
\text { after } 1,000 \mathrm{~h}\end{array}$ & Cu-based corrole HTL bolsters thermal stability & $\begin{array}{l}\text { Agresti et al. } \\
(2020)\end{array}$ \\
\hline $\begin{array}{l}\text { Damp } \\
\text { heat }\end{array}$ & $\mathrm{Cs}_{0.05}\left(\mathrm{MA}_{0.17} \mathrm{FA}_{0.83}\right)_{0.95} \mathrm{~Pb}\left(\mathrm{l}_{0.85} \mathrm{Br}_{0.15}\right)_{3}$ & $85^{\circ} \mathrm{C}, \mathrm{RH}=85 \%$ & $\begin{array}{l}90 \% \text { PCE retained } \\
\text { after } 500 \mathrm{~h}\end{array}$ & $\begin{array}{l}\text { Polydimethylsiloxane interlayer prevents } \\
\text { degradation of CuSCN HTL }\end{array}$ & $\begin{array}{l}\text { Kim et al. } \\
(2019 b)\end{array}$ \\
\hline $\begin{array}{l}\text { Damp } \\
\text { heat }\end{array}$ & $\mathrm{Cs}_{0.05}\left(\mathrm{MA}_{0.17} \mathrm{FA}_{0.83}\right)_{0.95} \mathrm{~Pb}\left(\mathrm{l}_{0.85} \mathrm{Br}_{0.15}\right)_{3}$ & $85^{\circ} \mathrm{C}, \mathrm{RH}=85 \%$ & $\begin{array}{l}\text { 90\% PCE retained } \\
\text { after } 720 \mathrm{~h}\end{array}$ & $\mathrm{Cu}_{2} \mathrm{O}-\mathrm{CuSCN}$ nanocomposite HTL & $\begin{array}{l}\text { Kim et al. } \\
\text { (2020b) }\end{array}$ \\
\hline $\begin{array}{l}\text { Damp } \\
\text { heat }\end{array}$ & $\left(\mathrm{FAPbl}_{3}\right)_{0.85}\left(\mathrm{MAPbBr}_{3}\right)_{0.15}$ & $85^{\circ} \mathrm{C}, \mathrm{RH}=85 \%$ & $\begin{array}{l}82 \% \text { PCE retained } \\
\text { after } 200 \mathrm{~h}\end{array}$ & $\begin{array}{l}\text { Green solvent-based spray-deposited NiO HTL } \\
\text { for an inverted device }\end{array}$ & $\begin{array}{l}\text { Kumar et al. } \\
\text { (2020) }\end{array}$ \\
\hline $\begin{array}{l}\text { IEC } \\
61215\end{array}$ & $\mathrm{FA}_{0.48} \mathrm{Cs}_{0.20} \mathrm{Pbl}_{2.27} \mathrm{Br}_{0.25}$ & $85^{\circ} \mathrm{C}, \mathrm{RH}=85 \%$ & $\begin{array}{l}77 \% \text { PCE retained } \\
\text { after } 192 \mathrm{~h}\end{array}$ & Moisture-resistant carbon electrode & Wu et al. (2019c) \\
\hline $\begin{array}{l}\text { Damp } \\
\text { heat }\end{array}$ & $\mathrm{Cs}_{0.05}\left(\mathrm{FA}_{0.85} \mathrm{MA}_{0.15}\right)_{0.95} \mathrm{~Pb}\left(\mathrm{l}_{0.85} \mathrm{Br}_{0.15}\right)_{3}$ & $85^{\circ} \mathrm{C}, \mathrm{RH}=85 \%$ & $\begin{array}{l}90 \% \text { PCE retained } \\
\text { after } 700 \mathrm{~h}\end{array}$ & 1,2,4-Triazole alloying stabilizes the perovskite & $\begin{array}{l}\text { Kim et al. } \\
\text { (2019a) }\end{array}$ \\
\hline
\end{tabular}

\section{Device to Module: Reliability of PSC, IEC Criterion}

The ultimate purpose of solar cell research is to produce commercial photovoltaic modules that can produce electricity for real-life affairs. An international standard for testing procedures and evaluation of performance and stability is highly needed. NASA's Jet Propulsion Laboratory launched a program in 1975 to start using solar cells in a large scale. That project attempted to identify failures of modules and how to duplicate the failures in shorter time scale to find solutions. That became the basis of establishing an international standard by the International Electrotechnical Commission (IEC) at Geneva, Switzerland. IEC sets up standards for testing of different solar modules (Kumar et al., 2020). The IEC standard protocol tests modules under various conditions (Wang et al., 2020a). Many tests are performed to investigate the electrical and mechanical qualities. Testing the environmental and operational stability is the most important part (Holzhey and Saliba, 2018). It consists of three steps:

1) Thermal cycling test: It tests the ability of the module toward thermal mismatch, fatigue and other stresses caused by fast change in temperature. Thermal cycling is performed from -40 to $80^{\circ} \mathrm{C}$ with a heating/cooling rate of $100^{\circ} \mathrm{C} / \mathrm{h}$, for maximum 200 cycles with maximum cycling time of $6 \mathrm{~h}$, minimum dwell time $10 \mathrm{~min}$.
2) Humidity-freeze test: This is performed to determine the ability of the module to withstand the effects of high temperature and humidity followed by low temperature. First, it is kept at $85^{\circ} \mathrm{C}$, RH of $85 \%$ for $20 \mathrm{~h}$ followed by rapid freezing to $0^{\circ} \mathrm{C}\left(100^{\circ} \mathrm{C} \mathrm{h}^{-1}\right.$ maximum $)$ and then to $-40^{\circ} \mathrm{C}$ for $4 \mathrm{~h}$. These can be repeated for maximum 10 cycles.

3) Damp heat test: It is carried out to test the performance of the module over long time under humidity. The module is tested under $85 \pm 2^{\circ} \mathrm{C}$ temperature, $85 \pm 5 \% \mathrm{RH}$ for $1,000 \mathrm{~h}$.

Holzhey and Saliba penned an excellent overview on this including a useful flowchart that can be a guide for researchers, who want to test devices for IEC 61215 (Holzhey and Saliba, 2018). In case of all the three tests, the requirement is that the degradation of PCE must not exceed 5\% of the value measured before the test. The perovskite solar cells are highly prone to degradation and the technology is also very new compared to Si-based or thin film-based solar cells. So, only a few reports are available on attempts to succeed the IEC criteria (Table 6). McGehee et al concentrated on encapsulation of PSCs and employed an effective packaging by taking in account multiple designing parameters (Cheacharoen et al., 2018). Their device succeeded the IEC 61215:2016 damp heat test. More than $90 \%$ of the PCE is retained after $1,000 \mathrm{~h}$ of operation at $85^{\circ} \mathrm{C}, 85 \%$ humidity (Figure $8 \mathrm{~B}$ ). The same encapsulation also helps the PSCs to succeed IEC 200 thermal 
cycles. Razera et al combined optical, electrical, and microstructural characterization to elucidate degradation paths and attempted to fabricate a PSC that can pass the IEC criteria (Razera et al., 2020). Mendes et al developed a laser-assisted hermetic encapsulation method, which is highly effective to protect the device from external factors and the devices are able to comply with the IEC 61646 standard (Emami et al., 2020; Emami et al., 2018). Lamination of the device using a conducting polymer doped by non-hygroscopic borane induces high stability and only $5.2 \%$ degradation of the PCE is observed after $1,000 \mathrm{~h}$ of damp-heat test at $85^{\circ} \mathrm{C}, 85 \%$ humidity (Heo et al., 2019). Ho-Baillie et al used gas chromatography-mass spectrometry to identify volatile products from PSC designed by them (Shi et al., 2020b). A cost-effective encapsulation is deliberated using polymer/glass stack where the polymer is injected after fixing the glass. A device with multiple A-site cation and multiple $\mathrm{X}$-site anion perovskite achieves and exceeds IEC 61215:2016 standard by surviving more than $1800 \mathrm{~h}$ of the damp heat test and 75 cycles of the humidity freeze test (Figures 8C,D). Han et al reported printable PSCs to qualify IEC61215:2016 criteria with 9,000 h of operational tracking. 5-ammoniumvaleric acid at grain boundaries inhibits decomposition, reconstruction, and irreversible ionic migration in the $\mathrm{MAPbI}_{3}$ perovskite (Mei et al., 2020). A few reports are available where the device is tested under damp-heat conditions at $85^{\circ} \mathrm{C}$ temperature and $85 \%$ relative humidity, but the degradation of PCE is far more than $5 \%$ (Table 7). Those results are also important because those can guide to adopt strategies to achieve highly stable PSCs. Inverted devices are often proven to be highly stable and moreover they are more suitable for tandem devices (Li et al., 2021b; Chen et al., 2021). Compositional engineering of the perovskite has primary importance (Kim et al., 2019a; Matsui et al., 2019). Several reports are available where highly stable devices are achieved by the modification of the charge-transporting layer or by modifying the interface by a stabilizing or hydrophobic material (Kim et al., 2019b; Lee et al., 2019; Agresti et al., 2020; Kim et al., 2020b; Kumar et al., 2020). Metal electrodes have been replaced by a carbon electrode that is water resistant and can improve stability (Wu et al., 2019c). It promises a cost-effective alternative to the noble metal-based electrodes. As discussed before, several encapsulation strategies are proven to be effective ( $\mathrm{Lv}$ et al., 2020). Reports on IEC 61215 and IEC 61646 test results on PSCs are listed in Tables 6, 7. In Table 6, the devices that passed (or nearly passed) the test are tabulated where Table 7 listed other excellent and representative results. The determining factors that enable exceptional stability in the mentioned devices are mentioned in the "Remarks" column.

\section{CONCLUSION AND OUTLOOK}

The PSCs' efficiency rapidly crossed 25\% for laboratory scale devices. But stability and reliability are needed to be developed quickly for commercialization. In fact, the commercialization needs simultaneous development of high efficiency devices with large area along with long-term stability. To prevent the degradation, understanding the mechanisms for degradation is highly valued. Promising development of power conversion efficiency of PSCs triggers a race to achieve higher efficiencies, but all the degradation pathways are not well understood until now. More research should be engaged for better understanding of degradation mechanisms. That knowledge will greatly help in adopting strategies to further improve the efficiency and stability of PSCs.

Various characterization methods of spectroscopy, electrochemistry, electron microscopy are employed to understand the degradation mechanisms in PSCs. Combination of these techniques with proper theoretical support can be helpful for better understanding of degradation. Various methods are employed to overcome the factors of instabilities. Many approaches are proven to be multitasking, i.e., one strategy or one added material can improve multiple factors. In between the recent trends, additive engineering is looking very promising. More research efforts should be engaged on various novel additives such as Lewis acid/base, IL, surface modifier. Those are proven to greatly influence the perovskite film and also can greatly help in stability from moisture and heat. Encapsulation is another important factor for commercialization. Most of the PSCs fully or partially passed the IEC criteria, all employed novel encapsulation methods. The causes of instability may lie on different factors of a particular device, so multipronged approaches can be effective to tackle those issues simultaneously and to produce a stable device with high efficiency. As the PSCs have already achieved satisfactory efficiency and the highest efficiencies are being updated quite swiftly, the focus should be concentrated on operational stability. Standard protocol for testing the operational stability has already been established. Any new device should be examined with the recommended standard of stability testing. Preparing a large-scale device is very important. These two can lead PSCs to solar module for practical application. Tandem devices where generally a Si-solar cell is attached with PSCs to harvest the lower energy solar photons not absorbed by perovskite are highly promising because the output can be enhanced while the stability of the PSC can be increased. The worldwide PSCs research community is already large and the volume of published literature is increasing every day. Establishing a database, customization and accepting standard testing protocols are the need of the hour.

\section{AUTHOR CONTRIBUTIONS}

SM has written the main draft of the manuscript. YZ and XZ have provided project motivation, guidance and corrected the manuscript. All authors contributed to the article and approved the submitted version.

\section{FUNDING}

The authors gratefully acknowledge the support from the National Key Research and Development Program of China (Grant No. 2018YFB1500103), the National Natural Science Foundation of China (Grant No. 61674084), the Overseas Expertise Introduction Project for Discipline Innovation of Higher Education of China (Grant No. B16027), the Tianjin Science and Technology Project (Grant No. 18ZXJMTG00220). Key R\&D Program of Hebei Province (No. 19214301D), and the Fundamental Research Funds for the Central Universities, Nankai University. 


\section{REFERENCES}

Abate, A., Leijtens, T., Pathak, S., Teuscher, J., Avolio, R., Errico, M. E., et al. (2013). Lithium Salts as "redox Active" P-type Dopants for Organic Semiconductors and Their Impact in Solid-State Dye-Sensitized Solar Cells. Phys. Chem. Chem. Phys. 15, 2572. doi:10.1039/c2cp44397j

Abdelmageed, G., Jewell, L., Hellier, K., Seymour, L., Luo, B., Bridges, F., et al. (2016). Mechanisms for Light Induced Degradation in MAPbI3 Perovskite Thin Films and Solar Cells. Appl. Phys. Lett. 109, 233905. doi:10.1063/ 1.4967840

Abdi-Jalebi, M., Andaji-Garmaroudi, Z., Cacovich, S., Stavrakas, C., Philippe, B., Richter, J. M., et al. (2018a). Maximizing and Stabilizing Luminescence from Halide Perovskites with Potassium Passivation. Nature 555, 497-501. doi:10.1038/nature25989

Abdi-Jalebi, M., Pazoki, M., Philippe, B., Dar, M. I., Alsari, M., Sadhanala, A., et al. (2018b). Dedoping of Lead Halide Perovskites Incorporating Monovalent Cations. Acs Nano 12, 7301-7311. doi:10.1021/acsnano.8b03586

Abrusci, A., Stranks, S. D., Docampo, P., Yip, H.-L., Jen, A. K.-Y., and Snaith, H. J. (2013). High-Performance Perovskite-Polymer Hybrid Solar Cells via Electronic Coupling with Fullerene Monolayers. Nano Lett. 13, 3124-3128. doi:10.1021/nl401044q

Abzieher, T., Moghadamzadeh, S., Schackmar, F., Eggers, H., Sutterlüti, F., Farooq, A., et al. (2019). Electron-Beam-Evaporated Nickel Oxide Hole Transport Layers for Perovskite-Based Photovoltaics. Adv. Energ. Mater. 9, 1802995. doi:10.1002/aenm.201802995

Agresti, A., Berionni Berna, B., Pescetelli, S., Catini, A., Menchini, F., Di Natale, C., et al. (2020). Copper-Based Corrole as Thermally Stable Hole Transporting Material for Perovskite Photovoltaics. Adv. Funct. Mater. 30, 2003790. doi:10.1002/adfm.202003790

Ahmad, S., Fu, P., Yu, S., Yang, Q., Liu, X., Wang, X., et al. (2019). Dion-Jacobson Phase 2D Layered Perovskites for Solar Cells with Ultrahigh Stability. Joule 3, 794-806. doi:10.1016/j.joule.2018.11.026

Ahn, N., Son, D.-Y., Jang, I.-H., Kang, S. M., Choi, M., and Park, N.-G. (2015). Highly Reproducible Perovskite Solar Cells with Average Efficiency of $18.3 \%$ and Best Efficiency of $19.7 \%$ Fabricated via Lewis Base Adduct of Lead(II) Iodide. J. Am. Chem. Soc. 137, 8696-8699. doi:10.1021/ jacs.5b04930

Aitola, K., Domanski, K., Correa-Baena, J.-P., Sveinbjörnsson, K., Saliba, M., Abate, A., et al. (2017). High Temperature-Stable Perovskite Solar Cell Based on LowCost Carbon Nanotube Hole Contact. Adv. Mater. 29, 1606398. doi:10.1002/ adma.201606398

Akin, S. (2019). Hysteresis-Free Planar Perovskite Solar Cells with a Breakthrough Efficiency of $22 \%$ and Superior Operational Stability over 2000 H. ACS Appl. Mater. Inter. 11, 39998-40005. doi:10.1021/ acsami.9b13876

Akin, S., Sadegh, F., Turan, S., and Sonmezoglu, S. (2019). Inorganic $\mathrm{CuFeO} 2$ Delafossite Nanoparticles as Effective Hole Transport Materials for Highly Efficient and Long-Term Stable Perovskite Solar Cells. ACS Appl. Mater. Inter. 11, 45142-45149. doi:10.1021/acsami.9b14740

Amat, A., Mosconi, E., Ronca, E., Quarti, C., Umari, P., Nazeeruddin, M. K., et al. (2014). Cation-Induced Band-Gap Tuning in Organohalide Perovskites: Interplay of Spin-Orbit Coupling and Octahedra Tilting. Nano Lett. 14, 3608-3616. doi:10.1021/nl5012992

Aristidou, N., Eames, C., Sanchez-Molina, I., Bu, X., Kosco, J., Islam, M. S., et al. (2017). Nat. Commun. 8, 15218. doi:10.1038/ncomms 15218

Arora, N., Dar, M. I., Hinderhofer, A., Pellet, N., Schreiber, F., Zakeeruddin, S. M., et al. (2017). Perovskite Solar Cells with CuSCN Hole Extraction Layers Yield Stabilized Efficiencies Greater Than 20\%. Science 358, 768-771. doi:10.1126/ science.aam 5655

Askar, A. M., Bernard, G. M., Wiltshire, B., Shankar, K., and Michaelis, V. K. (2017). Multinuclear Magnetic Resonance Tracking of Hydro, Thermal, and Hydrothermal Decomposition of CH3NH3PbI3. J. Phys. Chem. C 121, 1013-1024. doi:10.1021/acs.jpcc.6b10865

Bai, S., Da, P., Li, C., Wang, Z., Yuan, Z., Fu, F., et al. (2019). Planar Perovskite Solar Cells with Long-Term Stability Using Ionic Liquid Additives. Nature 571, 245-250. doi:10.1038/s41586-019-1357-2
Bailie, C. D., Unger, E. L., Zakeeruddin, S. M., Grätzel, M., and McGehee, M. D. (2014). Melt-infiltration of spiro-OMeTAD and thermal Instability of SolidState Dye-Sensitized Solar Cells. Phys. Chem. Chem. Phys. 16, 4864. doi:10.1039/c4cp00116h

Bang, S.-M., Shin, S. S., Jeon, N. J., Kim, Y. Y., Kim, G., Yang, T.-Y., et al. (2020). Defect-Tolerant Sodium-Based Dopant in Charge Transport Layers for Highly Efficient and Stable Perovskite Solar Cells. ACS Energ. Lett. 5, 1198-1205. doi:10.1021/acsenergylett.0c00514

Bartel, C. J., Sutton, C., Goldsmith, B. R., Ouyang, R., Musgrave, C. B., Ghiringhelli, L. M., et al. (2019). Sci. Adv. 5, eaav0693. doi:10.1126/sciadv.aav0693

Beal, R. E., Slotcavage, D. J., Leijtens, T., Bowring, A. R., Belisle, R. A., Nguyen, W. H., et al. (2016). Cesium Lead Halide Perovskites with Improved Stability for Tandem Solar Cells. J. Phys. Chem. Lett. 7, 746-751. doi:10.1021/ acs.jpclett.6b00002

Bella, F., Griffini, G., Correa-Baena, J.-P., Saracco, G., Gratzel, M., Hagfeldt, A., et al. (2016). Improving Efficiency and Stability of Perovskite Solar Cells with Photocurable Fluoropolymers. Science 354, 203-206. doi:10.1126/ science.aah4046

Bera, A., Sheikh, A. D., Haque, M. A., Bose, R., Alarousu, E., Mohammed, O. F., et al. (2015). Fast Crystallization and Improved Stability of Perovskite Solar Cells with Zn2SnO4 Electron Transporting Layer: Interface Matters. ACS Appl. Mater. Inter. 7, 28404-28411. doi:10.1021/acsami.5b09182

Bi, C., Zheng, X., Chen, B., Wei, H., and Huang, J. (2017). Spontaneous Passivation of Hybrid Perovskite by Sodium Ions from Glass Substrates: Mysterious Enhancement of Device Efficiency Revealed. ACS Energ. Lett. 2, 1400-1406. doi:10.1021/acsenergylett.7b00356

Bi, D., Yi, C., Luo, J., Decoppet, J.-D., Zhang, F., Zakeeruddin, S. M., et al. (2016). Nat. Energ. 1, 16142. doi:10.1038/nenergy.2016.142

Boyd, C. C., Cheacharoen, R., Bush, K. A., Prasanna, R., Leijtens, T., and McGehee, M. D. (2018). Barrier Design to Prevent Metal-Induced Degradation and Improve Thermal Stability in Perovskite Solar Cells. ACS Energ. Lett. 3, 1772-1778. doi:10.1021/acsenergylett.8b00926

Boyd, C. C., Cheacharoen, R., Leijtens, T., and McGehee, M. D. (2019). Understanding Degradation Mechanisms and Improving Stability of Perovskite Photovoltaics. Chem. Rev. 119, 3418-3451. doi:10.1021/ acs.chemrev.8b00336

Brenes, R., Guo, D., Osherov, A., Noel, N. K., Eames, C., Hutter, E. M., et al. (2017). Metal Halide Perovskite Polycrystalline Films Exhibiting Properties of Single Crystals. Joule 1, 155-167. doi:10.1016/j.joule.2017.08.006

Bush, K. A., Bailie, C. D., Chen, Y., Bowring, A. R., Wang, W., Ma, W., et al. (2016). Thermal and Environmental Stability of Semi-transparent Perovskite Solar Cells for Tandems Enabled by a Solution-Processed Nanoparticle Buffer Layer and Sputtered ITO Electrode. Adv. Mater. 28, 3937-3943. doi:10.1002/ adma.201505279

Bush, K. A., Frohna, K., Prasanna, R., Beal, R. E., Leijtens, T., Swifter, S. A., et al. (2018). Compositional Engineering for Efficient Wide Band Gap Perovskites with Improved Stability to Photoinduced Phase Segregation. ACS Energ. Lett. 3, 428-435. doi:10.1021/acsenergylett.7b01255

Bush, K. A., Palmstrom, A. F., Yu, Z. J., Boccard, M., Cheacharoen, R., Mailoa, J. P., et al. (2017). Nat. Energ. 2, 17009. doi:10.1038/nenergy.2017.9

Cai, Y., Cui, J., Chen, M., Zhang, M., Han, Y., Qian, F., et al. (2021). Multifunctional Enhancement for Highly Stable and Efficient Perovskite Solar Cells. Adv. Funct. Mater. 31, 2005776. doi:10.1002/adfm.202005776

Cao, J., Tao, S. X., Bobbert, P. A., Wong, C.-P., and Zhao, N. (2018). Interstitial Occupancy by Extrinsic Alkali Cations in Perovskites and its Impact on Ion Migration. Adv. Mater. 30, 1707350. doi:10.1002/ adma.201707350

Cappel, U. B., Svanström, S., Lanzilotto, V., Johansson, F. O. L., Aitola, K., Philippe, B., et al. (2017). Partially Reversible Photoinduced Chemical Changes in a Mixed-Ion Perovskite Material for Solar Cells. ACS Appl. Mater. Inter. 9, 34970-34978. doi:10.1021/acsami.7b10643

Chang, C.-Y., Lee, K.-T., Huang, W.-K., Siao, H.-Y., and Chang, Y.-C. (2015). High-Performance, Air-Stable, Low-Temperature Processed Semitransparent Perovskite Solar Cells Enabled by Atomic Layer Deposition. Chem. Mater. 27, 5122-5130. doi:10.1021/acs.chemmater.5b01933

Chang, C.-Y., and Wang, C.-C. (2020). Enhanced Stability and Performance of AirProcessed Perovskite Solar Cells via Defect Passivation with a Thiazole-Bridged 
Diketopyrrolopyrrole-Based $\pi$-conjugated Polymer. J. Mater. Chem. A. 8, 8593-8604. doi:10.1039/d0ta00978d

Chao, L., Niu, T., Gu, H., Yang, Y., Wei, Q., Xia, Y., et al. (2020). Research 2020, 2616345. doi:10.34133/2020/2616345

Charles, B., Dillon, J., Weber, O. J., Islam, M. S., and Weller, M. T. (2017). Understanding the Stability of Mixed A-Cation lead Iodide Perovskites. J. Mater. Chem. A. 5, 22495-22499. doi:10.1039/c7ta08617b

Chatterjee, S., and Pal, A. J. (2016). Introducing Cu2O Thin Films as a HoleTransport Layer in Efficient Planar Perovskite Solar Cell Structures. J. Phys. Chem. C 120, 1428-1437. doi:10.1021/acs.jpcc.5b11540

Cheacharoen, R., Boyd, C. C., Burkhard, G. F., Leijtens, T., Raiford, J. A., Bush, K. A., et al. (2018). Encapsulating Perovskite Solar Cells to Withstand Damp Heat and thermal Cycling. Sustain. Energ. Fuels 2, 2398-2406. doi:10.1039/ c8se00250a

Chen, B., Ren, N., Li, Y., Yan, L., Mazumdar, S., Zhao, Y., et al. (2021). Insights into the Development of Monolithic Perovskite/Silicon Tandem Solar Cells. Adv. Energ. Mater., 2003628. doi:10.1002/aenm.202003628

Chen, B., Rudd, P. N., Yang, S., Yuan, Y., and Huang, J. (2019). Imperfections and Their Passivation in Halide Perovskite Solar Cells. Chem. Soc. Rev. 48, 3842-3867. doi:10.1039/c8cs00853a

Chen, B., Yang, M., Priya, S., and Zhu, K. (2016). Origin of J-V Hysteresis in Perovskite Solar Cells. J. Phys. Chem. Lett. 7, 905-917. doi:10.1021/ acs.jpclett.6b00215

Chen, C.-Y., Lin, H.-Y., Chiang, K.-M., Tsai, W.-L., Huang, Y.-C., Tsao, C.-S., et al. (2017). All-Vacuum-Deposited Stoichiometrically Balanced Inorganic Cesium Lead Halide Perovskite Solar Cells with Stabilized Efficiency Exceeding 11\%. Adv. Mater. 29, 1605290. doi:10.1002/adma.201605290

Chen, W., Wu, Y., Yue, Y., Liu, J., Zhang, W., Yang, X., et al. (2015). Efficient and Stable Large-Area Perovskite Solar Cells with Inorganic Charge Extraction Layers. Science 350, 944-948. doi:10.1126/science.aad1015

Chiang, C.-H., and Wu, C.-G. (2016). Bulk Heterojunction Perovskite-PCBM Solar Cells with High Fill Factor. Nat. Photon 10, 196-200. doi:10.1038/ nphoton.2016.3

Christians, J. A., Miranda Herrera, P. A., and Kamat, P. V. (2015). Transformation of the Excited State and Photovoltaic Efficiency of CH3NH3PbI3Perovskite upon Controlled Exposure to Humidified Air. J. Am. Chem. Soc. 137, 1530-1538. doi:10.1021/ja511132a

Christians, J. A., Schulz, P., Tinkham, J. S., Schloemer, T. H., Harvey, S. P., Tremolet de Villers, B. J., et al. (2018). Tailored Interfaces of Unencapsulated Perovskite Solar Cells for $>1,000$ Hour Operational Stability. Nat. Energ. 3, 68-74. doi:10.1038/s41560-017-0067-y

Conings, B., Drijkoningen, J., Gauquelin, N., Babayigit, A., D’Haen, J., D'Olieslaeger, L., et al. (2015). Intrinsic Thermal Instability of Methylammonium Lead Trihalide Perovskite. Adv. Energ. Mater. 5, 1500477. doi:10.1002/aenm.201500477

DeQuilettes, D. W., Zhang, W., Burlakov, V. M., Graham, D. J., Leijtens, T., Osherov, A., et al. (2016). Nat. Commun. 7, 11683. doi:10.1038/ncomms 11683

Dhar, J., Sil, S., Dey, A., Ray, P. P., and Sanyal, D. (2017). Positron Annihilation Spectroscopic Investigation on the Origin of Temperature-dependent Electrical Response in Methylammonium Lead Iodide Perovskite. J. Phys. Chem. Lett. 8, 1745-1751. doi:10.1021/acs.jpclett.7b00446

Dhar, J., Sil, S., Hoque, N. A., Dey, A., Das, S., Ray, P. P., et al. (2018). Lattice-DefectInduced Piezo Response in Methylammonium-Lead-Iodide Perovskite Based Nanogenerator. Chemistryselect 3, 5304-5312. doi:10.1002/slct.201801034

Ding, Y., Wu, Y., Tian, Y., Xu, Y., Hou, M., Zhou, B., et al. (2021). Effects of Guanidinium Cations on Structural, Optoelectronic and Photovoltaic Properties of Perovskites. J. Energ. Chem. 58, 48-54. doi:10.1016/j.jechem.2020.09.036

Dkhissi, Y., Meyer, S., Chen, D., Weerasinghe, H. C., Spiccia, L., Cheng, Y.-B., et al. (2016). Stability Comparison of Perovskite Solar Cells Based on Zinc Oxide and Titania on Polymer Substrates. Chemsuschem 9, 687-695. doi:10.1002/cssc.201501659

Domanski, K., Correa-Baena, J.-P., Mine, N., Nazeeruddin, M. K., Abate, A., Saliba, M., et al. (2016). Not All that Glitters Is Gold: Metal-Migration-Induced Degradation in Perovskite Solar Cells. ACS Nano 10, 6306-6314. doi:10.1021/acsnano.6b02613

Domanski, K., Roose, B., Matsui, T., Saliba, M., Turren-Cruz, S.-H., Correa-Baena, J.-P., et al. (2017). Migration of Cations Induces Reversible Performance Losses over Day/night Cycling in Perovskite Solar Cells. Energy Environ. Sci. 10, 604-613. doi:10.1039/c6ee03352k
Dong, Q., Liu, F., Wong, M. K., Tam, H. W., Djurišić, A. B., Ng, A., et al. (2016). Encapsulation of Perovskite Solar Cells for High Humidity Conditions. ChemSusChem 9, 2597-2603. doi:10.1002/cssc.201600868

Du, J., Duan, J., Yang, X., Duan, Y., Zhou, Q., and Tang, Q. (2021). p -Type Charge Transfer Doping of Graphene Oxide with (NiCo) 1- Y Fe Y O X for Air-Stable, All-Inorganic CsPbIBr 2 Perovskite Solar Cells. Angew. Chem. Int. Ed. 60, 10608-10613. doi:10.1002/anie.202016703

Du, M., Zhu, X., Wang, L., Wang, H., Feng, J., Jiang, X., et al. (2020). High-Pressure Nitrogen-Extraction and Effective Passivation to Attain Highest Large-Area Perovskite Solar Module Efficiency. Adv. Mater. 32, 2004979. doi:10.1002/ adma.202004979

Duan, J., Zhao, Y., Wang, Y., Yang, X., and Tang, Q. (2019). Hole-Boosted $\mathrm{Cu}(\mathrm{Cr}, \mathrm{M}) \mathrm{O} 2$ Nanocrystals for All-Inorganic CsPbBr 3 Perovskite Solar Cells. Angew. Chem. Int. Ed. 58, 16147-16151. doi:10.1002/anie.201910843

Dulub, O., Batzilln, M., Solovev, S., Loginova, E., Alchagirov, A., Madey, T. E., et al. (2007). Electron-Induced Oxygen Desorption from the TiO2(011)-2x1 Surface Leads to SelfOrganized Vacancies. Science 317, 1052-1056. doi:10.1126/science.1144787

Dunfield, S. P., Bliss, L., Zhang, F., Luther, J. M., Zhu, K., Hest, M. F. A. M., et al. (2020). From Defects to Degradation: A Mechanistic Understanding of Degradation in Perovskite Solar Cell Devices and Modules. Adv. Energ. Mater. 10, 1904054. doi:10.1002/aenm.201904054

Emami, S., Martins, J., Ivanou, D., and Mendes, A. (2020). Advanced Hermetic Encapsulation of Perovskite Solar Cells: the Route to Commercialization. J. Mater. Chem. A. 8, 2654-2662. doi:10.1039/c9ta11907h

Emami, S., Martins, J., Madureira, R., Hernandez, D., Bernardo, G., Mendes, J., et al. (2018). J. Phys. D: Appl. Phys. 52, 074005. doi:10.1088/1361-6463/aaflf4

Eperon, G. E., Stranks, S. D., Menelaou, C., Johnston, M. B., Herz, L. M., and Snaith, H. J. (2014). Formamidinium lead Trihalide: a Broadly Tunable Perovskite for Efficient Planar Heterojunction Solar Cells. Energ. Environ. Sci. 7, 982-988. doi:10.1039/c3ee43822h

Ferdani, D. W., Pering, S. R., Ghosh, D., Kubiak, P., Walker, A. B., Lewis, S. E., et al. (2019). Partial Cation Substitution Reduces Iodide Ion Transport in lead Iodide Perovskite Solar Cells. Energ. Environ. Sci. 12, 2264-2272. doi:10.1039/c9ee00476a

Filip, M. R., Eperon, G. E., Snaith, H. J., and Giustino, F. (2014). Nat. Commun. 5, 5757. doi:10.1038/ncomms6757

Fu, Q., Xiao, S., Tang, X., Chen, Y., and Hu, T. (2019). Amphiphilic Fullerenes Employed to Improve the Quality of Perovskite Films and the Stability of Perovskite Solar Cells. ACS Appl. Mater. Inter. 11, 24782-24788. doi:10.1021/ acsami.9b07149

Gao, P., Bin Mohd Yusoff, A. R., and Nazeeruddin, M. K. (2018). Nat. Commun. 9, 5028. doi:10.1038/s41467-018-07382-9

Gholipour, S., Correa-Baena, J.-P., Domanski, K., Matsui, T., Steier, L., Giordano, F., et al. (2016). Highly Efficient and Stable Perovskite Solar Cells Based on a Low-Cost Carbon Cloth. Adv. Energ. Mater. 6, 1601116. doi:10.1002/ aenm.201601116

Ghosh, S., and Singh, T. (2019). Role of Ionic Liquids in Organic-Inorganic Metal Halide Perovskite Solar Cells Efficiency and Stability. Nano Energy 63, 103828. doi:10.1016/j.nanoen.2019.06.024

Gong, X., Guan, L., Pan, H., Sun, Q., Zhao, X., Li, H., et al. (2018). Highly Efficient Perovskite Solar Cells via Nickel Passivation. Adv. Funct. Mater. 28, 1804286. doi:10.1002/adfm.201804286

Grancini, G., Roldán-Carmona, C., Zimmermann, I., Mosconi, E., Lee, X., Martineau, D., et al. (2017). Nat. Commun. 8, 15684. doi:10.1038/ncomms15684

Guo, P., Ye, Q., Yang, X., Zhang, J., Xu, F., Shchukin, D., et al. (2019). Surface \& Grain Boundary Co-passivation by Fluorocarbon Based Bifunctional Molecules for Perovskite Solar Cells with Efficiency over 21\%. J. Mater. Chem. A. 7, 2497-2506. doi:10.1039/c8ta11524a

Habisreutinger, S. N., Leijtens, T., Eperon, G. E., Stranks, S. D., Nicholas, R. J., and Snaith, H. J. (2014). Carbon Nanotube/Polymer Composites as a Highly Stable Hole Collection Layer in Perovskite Solar Cells. Nano Lett. 14, 5561-5568. doi:10.1021/nl501982b

Hadadian, M., Smått, J.-H., and Correa-Baena, J.-P. (2020). The Role of CarbonBased Materials in Enhancing the Stability of Perovskite Solar Cells. Energ. Environ. Sci. 13, 1377-1407. doi:10.1039/c9ee04030g

Han, Y., Meyer, S., Dkhissi, Y., Weber, K., Pringle, J. M., Bach, U., et al. (2015). Degradation Observations of Encapsulated Planar CH3NH3PbI3 Perovskite Solar Cells at High Temperatures and Humidity. J. Mater. Chem. A. 3, 8139-8147. doi:10.1039/c5ta00358j 
Heo, J. H., Choi, Y. K., Koh, C. W., Woo, H. Y., and Im, S. H. (2019). Semitransparent FAPbI3- X Br X Perovskite Solar Cells Stable under Simultaneous Damp Heat $\left(85{ }^{\circ} \mathrm{C} / 85 \%\right)$ and 1 Sun Light Soaking. Adv. Mater. Technol. 4, 1800390. doi:10.1002/admt.201800390

Heo, J. H., Im, S. H., Noh, J. H., Mandal, T. N., Lim, C.-S., Chang, J. A., et al. (2013). Efficient Inorganic-Organic Hybrid Heterojunction Solar Cells Containing Perovskite Compound and Polymeric Hole Conductors. Nat. Photon 7, 486-491. doi:10.1038/nphoton.2013.80

Hoke, E. T., Slotcavage, D. J., Dohner, E. R., Bowring, A. R., Karunadasa, H. I., and McGehee, M. D. (2015). Reversible Photo-Induced Trap Formation in MixedHalide Hybrid Perovskites for Photovoltaics. Chem. Sci. 6, 613-617. doi:10.1039/c4sc03141e

Holzhey, P., and Saliba, M. (2018). A Full Overview of International Standards Assessing the Long-Term Stability of Perovskite Solar Cells. J. Mater. Chem. A. 6, 21794-21808. doi:10.1039/c8ta06950f

Hou, F., Han, C., Isabella, O., Yan, L., Shi, B., Chen, J., et al. (2019a). Inverted Pyramidally-Textured PDMS Antireflective Foils for Perovskite/silicon Tandem Solar Cells with Flat Top Cell. Nano Energy 56, 234-240. doi:10.1016/j.nanoen.2018.11.018

Hou, F., Shi, B., Li, T., Xin, C., Ding, Y., Wei, C., et al. (2019b). Efficient and Stable Perovskite Solar Cell Achieved with Bifunctional Interfacial Layers. ACS Appl. Mater. Inter. 11, 25218-25226. doi:10.1021/acsami.9b06424

Hou, M., Xu, Y., Zhou, B., Tian, Y., Wu, Y., Zhang, D., et al. (2020b). Aryl Diammonium Iodide Passivation for Efficient and Stable Hybrid OrganInorganic Perovskite Solar Cells. Adv. Funct. Mater. 30, 2002366. doi:10.1002/adfm.202002366

Hou, S., Shi, B., Wang, P., Li, Y., Zhang, J., Chen, P., et al. (2020a). Chin. Phys. B 29, 078801. doi:10.1088/1674-1056/ab99ae

Hou, Y., Quiroz, C. O. R., Scheiner, S., Chen, W., Stubhan, T., Hirsch, A., et al. (2015). Low-Temperature and Hysteresis-free Electron-Transporting Layers for Efficient, Regular, and Planar Structure Perovskite Solar Cells. Adv. Energ. Mater. 5, 1501056. doi:10.1002/aenm.201501056

Huang, C., Lin, P., Fu, N., Sun, K., Ye, M., Liu, C., et al. (2018). Ionic Liquid Modified SnO2 Nanocrystals as a Robust Electron Transporting Layer for Efficient Planar Perovskite Solar Cells. J. Mater. Chem. A. 6, 22086-22095. doi:10.1039/c8ta04131h

Huang, J.-S., Chou, C.-Y., and Lin, C.-F. (2010). Ieee Electron. Device Lett. 31, 332-334. doi:10.1109/LED.2009.2039846

Huang, P., Kazim, S., Wang, M., and Ahmad, S. (2019). Toward Phase Stability: Dion-Jacobson Layered Perovskite for Solar Cells. ACS Energ. Lett. 4, 2960-2974. doi:10.1021/acsenergylett.9b02063

Huang, Z., Proppe, A. H., Tan, H., Saidaminov, M. I., Tan, F., Mei, A., et al. (2019). Suppressed Ion Migration in Reduced-Dimensional Perovskites Improves Operating Stability. ACS Energ. Lett. 4, 1521-1527. doi:10.1021/ acsenergylett.9b00892

Hwang, I., Jeong, I., Lee, J., Ko, M. J., and Yong, K. (2015). Enhancing Stability of Perovskite Solar Cells to Moisture by the Facile Hydrophobic Passivation. ACS Appl. Mater. Inter. 7, 17330-17336. doi:10.1021/acsami.5b04490

Idígoras, J., Aparicio, F. J., Contreras-Bernal, L., Ramos-Terrón, S., Alcaire, M., Sánchez-Valencia, J. R., et al. (2018). Enhancing Moisture and Water Resistance in Perovskite Solar Cells by Encapsulation with Ultrathin Plasma Polymers. ACS Appl. Mater. Inter. 10, 11587-11594. doi:10.1021/acsami.7b17824

Ihly, R., Dowgiallo, A.-M., Yang, M., Schulz, P., Stanton, N. J., Reid, O. G., et al. (2016). Efficient Charge Extraction and Slow Recombination in OrganicInorganic Perovskites Capped with Semiconducting Single-Walled Carbon Nanotubes. Energ. Environ. Sci. 9, 1439-1449. doi:10.1039/c5ee03806e

Jang, J., Kim, Y. H., Park, S., Yoo, D., Cho, H., Jang, J., et al. (2021b). Extremely Stable Luminescent Crosslinked Perovskite Nanoparticles under Harsh Environments over 1.5 Years. Adv. Mater. 33, 2005255. doi:10.1002/ adma.202005255

Jang, Y.-W., Lee, S., Yeom, K. M., Jeong, K., Choi, K., Choi, M., et al. (2021a). Intact 2D/3D Halide junction Perovskite Solar Cells via Solid-phase In-Plane Growth. Nat. Energ. 6, 63-71. doi:10.1038/s41560-020-00749-7

Jena, A. K., Ikegami, M., and Miyasaka, T. (2017). Severe Morphological Deformation of Spiro-OMeTAD in (CH3NH3)PbI3 Solar Cells at High Temperature. ACS Energ. Lett. 2, 1760-1761. doi:10.1021/ acsenergylett.7b00582
Jena, A. K., Kulkarni, A., and Miyasaka, T. (2019). Halide Perovskite Photovoltaics: Background, Status, and Future Prospects. Chem. Rev. 119, 3036-3103. doi:10.1021/acs.chemrev.8b00539

Jeng, J.-Y., Chiang, Y.-F., Lee, M.-H., Peng, S.-R., Guo, T.-F., Chen, P., et al. (2013). CH3NH3PbI3Perovskite/Fullerene Planar-Heterojunction Hybrid Solar Cells. Adv. Mater. 25, 3727-3732. doi:10.1002/adma.201301327

Jeon, N. J., Noh, J. H., Kim, Y. C., Yang, W. S., Ryu, S., and Seok, S. I. (2014). Solvent Engineering for High-Performance Inorganic-Organic Hybrid Perovskite Solar Cells. Nat. Mater 13, 897-903. doi:10.1038/nmat4014

Jeon, N. J., Noh, J. H., Yang, W. S., Kim, Y. C., Ryu, S., Seo, J., et al. (2015). Compositional Engineering of Perovskite Materials for High-Performance Solar Cells. Nature 517, 476-480. doi:10.1038/nature14133

Jeong, M., Choi, I. W., Go, E. M., Cho, Y., Kim, M., Lee, B., et al. (2020). Stable Perovskite Solar Cells with Efficiency Exceeding 24.8\% and 0.3-V Voltage Loss. Science 369, 1615-1620. doi:10.1126/science.abb7167

Ji, X., Zhou, T., Ke, X., Wang, W., Wu, S., Zhang, M., et al. (2020). A Mixed Hole Transport Material Employing a Highly Planar Conjugated Molecule for Efficient and Stable Perovskite Solar Cells. J. Mater. Chem. A. 8, 5163-5170. doi:10.1039/c9ta13365h

Jiang, X., Zhang, J., Ahmad, S., Tu, D., Liu, X., Jia, G., et al. (2020). Dion-Jacobson 2D-3D Perovskite Solar Cells with Improved Efficiency and Stability. Nano Energy 75, 104892. doi:10.1016/j.nanoen.2020.104892

Jiang, Y., Qiu, L., Juarez-Perez, E. J., Ono, L. K., Hu, Z., Liu, Z., et al. (2019). Reduction of lead Leakage from Damaged lead Halide Perovskite Solar Modules Using Self-Healing Polymer-Based Encapsulation. Nat. Energ. 4, 585-593. doi:10.1038/s41560-019-0406-2

Jodlowski, A. D., Roldán-Carmona, C., Grancini, G., Salado, M., Ralaiarisoa, M., Ahmad, S., et al. (2017). Large Guanidinium Cation Mixed with Methylammonium in lead Iodide Perovskites for 19\% Efficient Solar Cells. Nat. Energ. 2, 972-979. doi:10.1038/s41560-017-0054-3

Juarez-Perez, E. J., Hawash, Z., Raga, S. R., Ono, L. K., and Qi, Y. (2016). Thermal Degradation of $\mathrm{CH} 3 \mathrm{NH} 3 \mathrm{PbI} 3$ Perovskite into NH3 and CH3I Gases Observed by Coupled Thermogravimetry-Mass Spectrometry Analysis. Energ. Environ. Sci. 9, 3406-3410. doi:10.1039/c6ee02016j

Jung, E. H., Jeon, N. J., Park, E. Y., Moon, C. S., Shin, T. J., Yang, T.-Y., et al. (2019). Efficient, Stable and Scalable Perovskite Solar Cells Using Poly(3Hexylthiophene). Nature 567, 511-515. doi:10.1038/s41586-019-1036-3

Jung, J. W., Chueh, C.-C., and Jen, A. K.-Y. (2015). A Low-Temperature, SolutionProcessable, Cu-Doped Nickel Oxide Hole-Transporting Layer via the Combustion Method for High-Performance Thin-Film Perovskite Solar Cells. Adv. Mater. 27, 7874-7880. doi:10.1002/adma.201503298

Kang, J., and Wang, L.-W. (2017). High Defect Tolerance in Lead Halide Perovskite CsPbBr3. J. Phys. Chem. Lett. 8, 489-493. doi:10.1021/acs.jpclett.6b02800

Kato, Y., Ono, L. K., Lee, M. V., Wang, S., Raga, S. R., and Qi, Y. (2015). Silver Iodide Formation in Methyl Ammonium Lead Iodide Perovskite Solar Cells with Silver Top Electrodes. Adv. Mater. Inter. 2, 1500195. doi:10.1002/admi.201500195

Kempe, M. (2017). Encapsulant Materials for PV Modules, in Photovoltaic Solar Energy (Chichester, UK: John Wiley \& Sons, Ltd), 478-490.

Kieslich, G., Sun, S., and Cheetham, A. K. (2014). Solid-state Principles Applied to Organic-Inorganic Perovskites: New Tricks for an Old Dog. Chem. Sci. 5, 4712-4715. doi:10.1039/c4sc02211d

Kim, D. H., Han, G. S., Seong, W. M., Lee, J.-W., Kim, B. J., Park, N.-G., et al. (2015). Niobium Doping Effects on TiO2Mesoscopic Electron Transport LayerBased Perovskite Solar Cells. Chemsuschem 8, 2392-2398. doi:10.1002/ cssc. 201403478

Kim, G., Min, H., Lee, K. S., Lee, D. Y., Yoon, S. M., and Seok, S. I. (2020). Impact of Strain Relaxation on Performance of $\alpha$-formamidinium lead Iodide Perovskite Solar Cells. Science 370, 108-112. doi:10.1126/science.abc4417

Kim, G. Y., Senocrate, A., Yang, T.-Y., Gregori, G., Grätzel, M., and Maier, J. (2018). Large Tunable Photoeffect on Ion Conduction in Halide Perovskites and Implications for Photodecomposition. Nat. Mater 17, 445-449. doi:10.1038/ s41563-018-0038-0

Kim, H.-S., Lee, C.-R., Im, J.-H., Lee, K.-B., Moehl, T., Marchioro, A., et al. (2012). Scientific Rep. 2, 591. doi:10.1038/srep00591

Kim, J., Lee, Y., Gil, B., Yun, A. J., Kim, J., Woo, H., et al. (2020b). A Cu2O-CuSCN Nanocomposite as a Hole-Transport Material of Perovskite Solar Cells for Enhanced Carrier Transport and Suppressed Interfacial Degradation. ACS Appl. Energ. Mater. 3, 7572-7579. doi:10.1021/acsaem.0c01001 
Kim, J., Lee, Y., Yun, A. J., Gil, B., and Park, B. (2019b). Interfacial Modification and Defect Passivation by the Cross-Linking Interlayer for Efficient and Stable CuSCN-Based Perovskite Solar Cells. ACS Appl. Mater. Inter. 11, 46818-46824. doi:10.1021/acsami.9b16194

Kim, J., Yun, A. J., Gil, B., Lee, Y., and Park, B. (2019a). Triamine-Based Aromatic Cation as a Novel Stabilizer for Efficient Perovskite Solar Cells. Adv. Funct. Mater. 29, 1905190. doi:10.1002/adfm.201905190

Kim, N.-K., Min, Y. H., Noh, S., Cho, E., Jeong, G., Joo, M., et al. (2017). Scientific Rep. 7, 4645. doi:10.1038/s41598-017-04690-w

Kim, Y. C., Jeon, N. J., Noh, J. H., Yang, W. S., Seo, J., Yun, J. S., et al. (2016). Beneficial Effects of PbI2Incorporated in Organo-Lead Halide Perovskite Solar Cells. Adv. Energ. Mater. 6, 1502104. doi:10.1002/aenm.201502104

Kojima, A., Teshima, K., Shirai, Y., and Miyasaka, T. (2009). Organometal Halide Perovskites as Visible-Light Sensitizers for Photovoltaic Cells. J. Am. Chem. Soc. 131, 6050-6051. doi:10.1021/ja809598r

Kooijman, A., Muscarella, L. A., and Williams, R. M. (2019). Perovskite Thin Film Materials Stabilized and Enhanced by Zinc(II) Doping. Appl. Sci. 9, 1678. doi:10.3390/app9081678

Kubicki, D. J., Prochowicz, D., Hofstetter, A., Zakeeruddin, S. M., Grätzel, M., and Emsley, L. (2017). Phase Segregation in Cs-, Rb- and K-Doped Mixed-Cation (MA)X(FA)1-xPbI3 Hybrid Perovskites from Solid-State NMR. J. Am. Chem. Soc. 139, 14173-14180. doi:10.1021/jacs.7b07223

Kumar, N., Lee, H. B., Hwang, S., and Kang, J.-W. (2020). Large-area, green Solvent spray Deposited Nickel Oxide Films for Scalable Fabrication of Triple-Cation Perovskite Solar Cells. J. Mater. Chem. A. 8, 3357-3368. doi: $10.1039 / \mathrm{c} 9 \mathrm{ta} 13528 \mathrm{f}$

Lai, H., Kan, B., Liu, T., Zheng, N., Xie, Z., Zhou, T., et al. (2018). Two-Dimensional Ruddlesden-Popper Perovskite with Nanorod-like Morphology for Solar Cells with Efficiency Exceeding 15\%. J. Am. Chem. Soc. 140, 11639-11646. doi:10.1021/jacs.8b04604

Lee, B., Stoumpos, C. C., Zhou, N., Hao, F., Malliakas, C., Yeh, C.-Y., et al. (2014). Air-Stable Molecular Semiconducting Iodosalts for Solar Cell Applications: Cs2SnI6 as a Hole Conductor. J. Am. Chem. Soc. 136, 15379-15385. doi:10.1021/ja508464w

Lee, B., Yun, A. J., Kim, J., Gil, B., Shin, B., and Park, B. (2019). AminosilaneModified $\mathrm{CuGaO} 2$ Nanoparticles Incorporated with $\mathrm{CuSCN}$ as a HoleTransport Layer for Efficient and Stable Perovskite Solar Cells. Adv. Mater. Inter. 6, 1901372. doi:10.1002/admi.201901372

Lee, H. B., Kumar, N., Tyagi, B., Ko, K.-J., and Kang, J.-W. (2021). Dimensionality and Defect Engineering Using Fluoroaromatic Cations for Efficiency and Stability Enhancement in 3D/2D Perovskite Photovoltaics. Sol. RRL 5, 2000589. doi:10.1002/solr.202000589

Lee, J.-W., Bae, S.-H., De Marco, N., Hsieh, Y.-T., Dai, Z., and Yang, Y. (2018). The Role of Grain Boundaries in Perovskite Solar Cells. Mater. Today Energ. 7, 149-160. doi:10.1016/j.mtener.2017.07.014

Lee, J.-W., Bae, S.-H., Hsieh, Y.-T., De Marco, N., Wang, M., Sun, P., et al. (2017). A Bifunctional Lewis Base Additive for Microscopic Homogeneity in Perovskite Solar Cells. Chem 3, 290-302. doi:10.1016/j.chempr.2017.05.020

Lee, J.-W., Kim, D.-H., Kim, H.-S., Seo, S.-W., Cho, S. M., and Park, N.-G. (2015). Formamidinium and Cesium Hybridization for Photo- and Moisture-Stable Perovskite Solar Cell. Adv. Energ. Mater. 5, 1501310. doi:10.1002/ aenm. 201501310

Lee, J.-W., Kim, H.-S., and Park, N.-G. (2016). Lewis Acid-Base Adduct Approach for High Efficiency Perovskite Solar Cells. Acc. Chem. Res. 49, 311-319. doi:10.1021/acs.accounts.5b00440

Lee, J.-W., Seol, D.-J., Cho, A.-N., and Park, N.-G. (2014). High-Efficiency Perovskite Solar Cells Based on the Black Polymorph of HC(NH2)2PbI3. Adv. Mater. 26, 4991-4998. doi:10.1002/adma.201401137

Lee, Y. I., Jeon, N. J., Kim, B. J., Shim, H., Yang, T.-Y., Seok, S. I., et al. (2018). A Low-Temperature Thin-Film Encapsulation for Enhanced Stability of a Highly Efficient Perovskite Solar Cell. Adv. Energ. Mater. 8, 1701928. doi:10.1002/ aenm.201701928

Leguy, A. M. A., Hu, Y., Campoy-Quiles, M., Alonso, M. I., Weber, O. J., Azarhoosh, P., et al. (2015). Reversible Hydration of CH3NH3PbI3in Films, Single Crystals, and Solar Cells. Chem. Mater. 27, 3397-3407. doi:10.1021/ acs.chemmater.5b00660

Leijtens, T., Lauber, B., Eperon, G. E., Stranks, S. D., and Snaith, H. J. (2014). The Importance of Perovskite Pore Filling in Organometal Mixed Halide Sensitized
TiO2-Based Solar Cells. J. Phys. Chem. Lett. 5, 1096-1102. doi:10.1021/ jz500209g

Li, H., Li, D., Zhao, W., Yuan, S., Liu, Z., Wang, D., et al. (2020). NaCl-assisted Defect Passivation in the Bulk and Surface of TiO2 Enhancing Efficiency and Stability of Planar Perovskite Solar Cells. J. Power Sourc. 448, 227586. doi:10.1016/j.jpowsour.2019.227586

Li, N., Niu, X., Chen, Q., and Zhou, H. (2020). Towards Commercialization: the Operational Stability of Perovskite Solar Cells. Chem. Soc. Rev. 49, 8235-8286. doi: $10.1039 / \mathrm{d} 0 \mathrm{cs} 00573 \mathrm{~h}$

Li, N., Tao, S., Chen, Y., Niu, X., Onwudinanti, C. K., Hu, C., et al. (2019). Cation and Anion Immobilization through Chemical Bonding Enhancement with Fluorides for Stable Halide Perovskite Solar Cells. Nat. Energ. 4, 408-415. doi:10.1038/s41560-019-0382-6

Li, R., Wang, P., Chen, B., Cui, X., Ding, Y., Li, Y., et al. (2020). NiOx/Spiro Hole Transport Bilayers for Stable Perovskite Solar Cells with Efficiency Exceeding 21\%. ACS Energ. Lett. 5, 79-86. doi:10.1021/acsenergylett.9b02112

Li, W., Zhang, W., Van Reenen, S., Sutton, R. J., Fan, J., Haghighirad, A. A., et al. (2016). Enhanced UV-Light Stability of Planar Heterojunction Perovskite Solar Cells with Caesium Bromide Interface Modification. Energ. Environ. Sci. 9, 490-498. doi:10.1039/c5ee03522h

Li, X., Xu, Q., Yan, L., Ren, C., Shi, B., and Wang, P. (2021b). Nanophotonics, 10, 2001-2022. https: doi:10.1021/acsnano.1c02191

Li, X., Fu, S., Liu, S., Wu, Y., Zhang, W., Song, W., et al. (2019). Suppressing the Ions-Induced Degradation for Operationally Stable Perovskite Solar Cells. Nano Energy 64, 103962. doi:10.1016/j.nanoen.2019.103962

Li, X., Hoffman, J. M., and Kanatzidis, M. G. (2021). The 2D Halide Perovskite Rulebook: How the Spacer Influences Everything from the Structure to Optoelectronic Device Efficiency. Chem. Rev. 121, 2230-2291. doi:10.1021/ acs.chemrev.0c01006

Li, X., Ke, W., Traoré, B., Guo, P., Hadar, I., Kepenekian, M., et al. (2019). TwoDimensional Dion-Jacobson Hybrid Lead Iodide Perovskites with Aromatic Diammonium Cations. J. Am. Chem. Soc. 141, 12880-12890. doi:10.1021/ jacs. $9 \mathrm{~b} 06398$

Li, X., Tschumi, M., Han, H., Babkair, S. S., Alzubaydi, R. A., Ansari, A. A., et al. (2015). Outdoor Performance and Stability under Elevated Temperatures and Long-Term Light Soaking of Triple-Layer Mesoporous Perovskite Photovoltaics. Energ. Technol. 3, 551-555. doi:10.1002/ente.201500045

Li, Z., Xiao, C., Yang, Y., Harvey, S. P., Kim, D. H., Christians, J. A., et al. (2017). Extrinsic Ion Migration in Perovskite Solar Cells. Energ. Environ. Sci. 10, 1234-1242. doi:10.1039/c7ee00358g

Li, Z., Yang, M., Park, J.-S., Wei, S.-H., Berry, J. J., and Zhu, K. (2016). Stabilizing Perovskite Structures by Tuning Tolerance Factor: Formation of Formamidinium and Cesium Lead Iodide Solid-State Alloys. Chem. Mater. 28, 284-292. doi:10.1021/acs.chemmater.5b04107

Liang, C., Gu, H., Xia, Y., Wang, Z., Liu, X., Xia, J., et al. (2021). Two-dimensional Ruddlesden-Popper Layered Perovskite Solar Cells Based on Phase-Pure Thin Films. Nat. Energ. 6, 38-45. doi:10.1038/s41560-020-00721-5

Liang, C., Zhao, D., Li, Y., Li, X., Peng, S., Shao, G., et al. (2018). RuddlesdenPopper Perovskite for Stable Solar Cells. Energy Environ. Mater. 1, 221-231. doi:10.1002/eem2.12022

Lim, K.-G., Kim, H.-B., Jeong, J., Kim, H., Kim, J. Y., and Lee, T.-W. (2014). Boosting the Power Conversion Efficiency of Perovskite Solar Cells Using SelfOrganized Polymeric Hole Extraction Layers with High Work Function. Adv. Mater. 26, 6461-6466. doi:10.1002/adma.201401775

Lin, J., Lai, M., Dou, L., Kley, C. S., Chen, H., Peng, F., et al. (2018). Thermochromic Halide Perovskite Solar Cells. Nat. Mater 17, 261-267. doi:10.1038/s41563-0170006-0

Liu, C., Hu, M., Zhou, X., Wu, J., Zhang, L., Kong, W., et al. (2018). Efficiency and Stability Enhancement of Perovskite Solar Cells by Introducing CsPbI3 Quantum Dots as an Interface Engineering Layer. NPG Asia Mater. 10, 552-561. doi:10.1038/s41427-018-0055-0

Liu, C., Li, W., Li, H., Zhang, C., Fan, J., and Mai, Y. (2017). C60 Additive-Assisted Crystallization in CH3NH3Pb0.75Sn0.25I3 Perovskite Solar Cells with High Stability and Efficiency. Nanoscale 9, 13967-13975. doi:10.1039/c7nr03507a

Liu, C., Qiu, Z., Meng, W., Chen, J., Qi, J., Dong, C., et al. (2015). Effects of Interfacial Characteristics on Photovoltaic Performance in $\mathrm{CH} 3 \mathrm{NH} 3 \mathrm{PbBr} 3$ based Bulk Perovskite Solar Cells with Core/shell Nanoarray as Electron Transporter. Nano Energy 12, 59-68. doi:10.1016/j.nanoen.2014.12.004 
Liu, P., Han, N., Wang, W., Ran, R., Zhou, W., and Shao, Z. (2021). HighQuality Ruddlesden-Popper Perovskite Film Formation for HighPerformance Perovskite Solar Cells. Adv. Mater. 33, 2002582. doi:10.1002/adma.202002582

Liu, T., Guo, J., Lu, D., Xu, Z., Fu, Q., Zheng, N., et al. (2021a). ACS Nano, doi:10.1021/acsnano.1021c02191

Liu, X., Wu, J., Yang, Y., Wu, T., and Guo, Q. (2018). Pyridine Solvent Engineering for High Quality Anion-Cation-Mixed Hybrid and High Performance of Perovskite Solar Cells. J. Power Sourc. 399, 144-150. doi:10.1016/ j.jpowsour.2018.07.093

Liu, Y., Akin, S., Pan, L., Uchida, R., Arora, N., Milic, J. V., et al. (2019). Sci. Adv. 5, eaaw2543. doi:10.1126/sciadv.aaw2543

Lu, H., Liu, Y., Ahlawat, P., Mishra, A., Tress, W. R., Eickemeyer, F. T., et al. (2020). Science 370, eabb8985. doi:10.1126/science.abb8985

Luo, J., Xia, J., Yang, H., Malik, H. A., Han, F., Shu, H., et al. (2020). Novel Approach toward Hole-Transporting Layer Doped by Hydrophobic Lewis Acid through Infiltrated Diffusion Doping for Perovskite Solar Cells. Nano Energy 70, 104509. doi:10.1016/j.nanoen.2020.104509

Lv, Y., Zhang, H., Liu, R., Sun, Y., and Huang, W. (2020). Composite Encapsulation Enabled Superior Comprehensive Stability of Perovskite Solar Cells. ACS Appl. Mater. Inter. 12, 27277-27285. doi:10.1021/acsami.0c06823

Ma, S., Bai, Y., Wang, H., Zai, H., Wu, J., Li, L., et al. (2020). 1000 H Operational Lifetime Perovskite Solar Cells by Ambient Melting Encapsulation. Adv. Energ. Mater. 10, 1902472. doi:10.1002/aenm.201902472

Ma, X., Yang, L., Lei, K., Zheng, S., Chen, C., and Song, H. (2020). Doping in Inorganic Perovskite for Photovoltaic Application. Nano Energy 78, 105354. doi:10.1016/j.nanoen.2020.105354

MacFarlane, D. R., Forsyth, M., Howlett, P. C., Kar, M., Passerini, S., Pringle, J. M., et al. (2016). Nat. Rev. Mater. 1, 15005. doi:10.1038/natrevmats.2015.5

Mahmood, K., Swain, B. S., Kirmani, A. R., and Amassian, A. (2015). Highly Efficient Perovskite Solar Cells Based on a Nanostructured WO3-TiO2coreShell Electron Transporting Material. J. Mater. Chem. A. 3, 9051-9057. doi:10.1039/c4ta04883k

Mao, L., Ke, W., Pedesseau, L., Wu, Y., Katan, C., Even, J., et al. (2018). Hybrid Dion-Jacobson 2D Lead Iodide Perovskites. J. Am. Chem. Soc. 140, 3775-3783. doi:10.1021/jacs.8b00542

Mateker, W. R., and McGehee, M. D. (2017). Progress in Understanding Degradation Mechanisms and Improving Stability in Organic Photovoltaics. Adv. Mater. 29, 1603940. doi:10.1002/adma.201603940

Matsui, T., Yamamoto, T., Nishihara, T., Morisawa, R., Yokoyama, T., Sekiguchi, T., et al. (2019). Compositional Engineering for Thermally Stable, Highly Efficient Perovskite Solar Cells Exceeding 20\% Power Conversion Efficiency with $85{ }^{\circ} \mathrm{C} / 85 \% 1000 \mathrm{H}$ Stability. Adv. Mater. 31, 1806823. doi:10.1002/ adma.201806823

Mazumdar, S., and Bhattacharyya, A. J. (2013). Dependence of Electron Recombination Time and Light to Electricity Conversion Efficiency on Shape of the Nanocrystal Light Sensitizer. Energ. Environ. Sci. 6, 1494-1498. doi:10.1039/c3ee00120b

Mazumdar, S., and Bhattacharyya, A. J. (2015). One-pot Synthesis of a TiO2-CdS Nano-Heterostructure Assembly with Enhanced Photocatalytic Activity. RSC Adv. 5, 34942-34948. doi:10.1039/c5ra04733a

Mazumdar, S., and Bhattacharyya, A. J. (2012). Shape Effect on Electronic and Photovoltaic Properties of CdS Nanocrystals. $j$ nanosci nanotechnol 12, 6308-6314. doi:10.1166/jnn.2012.6432

Mazumdar, S., Du, B., Huang, C., Lin, P., Zhao, J., Zeng, X., et al. (2019). Designing Electron Transporting Layer for Efficient Perovskite Solar Cell by Deliberating over Nano-Electrical Conductivity. Solar Energ. Mater. Solar Cell, 200, 109995. doi:10.1016/j.solmat.2019.109995

Mazumdar, S., Du, B., Lin, P., Zeng, X., and Ke, S. (2020). Nano-electrical Conductivity Guided Optimization of Pulsed Laser Deposited ZnO Electron Transporting Layer for Efficient Perovskite Solar Cell. J. Power Sourc. 468, 228392. doi:10.1016/j.jpowsour.2020.228392

Mazumdar, S., Roy, K., Srihari, V., Umapathy, S., and Bhattacharyya, A. J. (2015). Probing Ultrafast Photoinduced Electron Transfer to $\mathrm{TiO} 2$ from CdS Nanocrystals of Varying Crystallographic Phase Content. J. Phys. Chem. C 119, 17466-17473. doi:10.1021/acs.jpcc.5b05607

Mazumdar, S., Tamilselvan, M., and Bhattacharyya, A. J. (2015). Optimizing Photovoltaic Response by Tuning Light-Harvesting Nanocrystal Shape
Synthesized Using a Quick Liquid-Gas Phase Reaction. ACS Appl. Mater. Inter. 7, 28188-28196. doi:10.1021/acsami.5b08595

McMeekin, D. P., Sadoughi, G., Rehman, W., Eperon, G. E., Saliba, M., Hörantner, M. T., et al. (2016). A Mixed-Cation lead Mixed-Halide Perovskite Absorber for Tandem Solar Cells. Science 351, 151-155. doi: $10.1126 /$ science.aad5845

Mei, A., Li, X., Liu, L., Ku, Z., Liu, T., Rong, Y., et al. (2014). A Hole-conductor-free, Fully Printable Mesoscopic Perovskite Solar Cell with High Stability. Science 345, 295-298. doi:10.1126/science. 1254763

Mei, A., Sheng, Y., Ming, Y., Hu, Y., Rong, Y., Zhang, W., et al. (2020). Stabilizing Perovskite Solar Cells to IEC61215:2016 Standards with over 9,000-h Operational Tracking. Joule 4, 2646-2660. doi:10.1016/j.joule.2020.09.010

Mosconi, E., Meggiolaro, D., Snaith, H. J., Stranks, S. D., and De Angelis, F. (2016). Light-induced Annihilation of Frenkel Defects in Organo-lead Halide Perovskites. Energ. Environ. Sci. 9, 3180-3187. doi:10.1039/c6ee01504b

Na Quan, L., Ma, D., Zhao, Y., Voznyy, O., Yuan, H., Bladt, E., et al. (2020). Nat. Commun. 11, 170. doi:10.1038/s41467-019-13944-2

Nagabhushana, G. P., Shivaramaiah, R., and Navrotsky, A. (2016). Direct Calorimetric Verification of Thermodynamic Instability of lead Halide Hybrid Perovskites. Proc. Natl. Acad. Sci. USA 113, 7717-7721. doi:10.1073/ pnas. 1607850113

Neophytou, M., De Bastiani, M., Gasparini, N., Aydin, E., Ugur, E., Seitkhan, A., et al. (2019). Enhancing the Charge Extraction and Stability of Perovskite Solar Cells Using Strontium Titanate (SrTiO3) Electron Transport Layer. ACS Appl. Energ. Mater. 2, 8090-8097. doi:10.1021/acsaem.9b01567

Niu, T., Ren, H., Wu, B., Xia, Y., Xie, X., Yang, Y., et al. (2019). Reduced-Dimensional Perovskite Enabled by Organic Diamine for Efficient Photovoltaics. J. Phys. Chem. Lett. 10, 2349-2356. doi:10.1021/acs.jpclett.9b00750

Noh, J. H., Im, S. H., Heo, J. H., Mandal, T. N., and Seok, S. I. (2013). Chemical Management for Colorful, Efficient, and Stable Inorganic-Organic Hybrid Nanostructured Solar Cells. Nano Lett. 13, 1764-1769. doi:10.1021/nl400349b

Paritmongkol, W., Dahod, N. S., Stollmann, A., Mao, N., Settens, C., Zheng, S.-L., et al. (2019). Synthetic Variation and Structural Trends in Layered TwoDimensional Alkylammonium Lead Halide Perovskites. Chem. Mater. 31, 5592-5607. doi:10.1021/acs.chemmater.9b01318

Peng, J., Walter, D., Ren, Y., Tebyetekerwa, M., Wu, Y., Duong, T., et al. (2021). Nanoscale Localized Contacts for High Fill Factors in Polymer-Passivated Perovskite Solar Cells. Science 371, 390-395. doi:10.1126/science.abb8687

Peng, Z., Wei, Q., Chen, H., Liu, Y., Wang, F., Jiang, X., et al. (2020). Cs0.15FA0.85PbI3/CsxFA1-xPbI3 Core/Shell Heterostructure for Highly Stable and Efficient Perovskite Solar Cells. Cel Rep. Phys. Sci. 1, 100224. doi:10.1016/j.xcrp.2020.100224

Pering, S. R., Deng, W., Troughton, J. R., Kubiak, P. S., Ghosh, D., Niemann, R. G., et al. (2017). Azetidinium lead Iodide for Perovskite Solar Cells. J. Mater. Chem. A. 5, 20658-20665. doi:10.1039/c7ta07545f

Poglitsch, A., and Weber, D. (1987). Dynamic Disorder in Methylammoniumtrihalogenoplumbates (II) Observed by Millimeter-wave Spectroscopy. J. Chem. Phys. 87, 6373-6378. doi:10.1063/1.453467

Poindexter, J. R., Hoye, R. L. Z., Nienhaus, L., Kurchin, R. C., Morishige, A. E., Looney, E. E., et al. (2017). High Tolerance to Iron Contamination in Lead Halide Perovskite Solar Cells. Acs Nano 11, 7101-7109. doi:10.1021/acsnano.7b02734

Premalal, E. V. A., Dematage, N., Kumara, G. R. R. A., Rajapakse, R. M. G., Shimomura, M., Murakami, K., et al. (2012). Preparation of Structurally Modified, Conductivity Enhanced-P-CuSCN and its Application in DyeSensitized Solid-State Solar Cells. J. Power Sourc. 203, 288-296. doi:10.1016/ j.jpowsour.2011.12.034

Qi, W., Zhou, X., Li, J., Cheng, J., Li, Y., Ko, M. J., et al. (2020). Inorganic Material Passivation of Defects toward Efficient Perovskite Solar Cells. Sci. Bull. 65, 2022-2032. doi:10.1016/j.scib.2020.07.017

Qin, M., Cao, J., Zhang, T., Mai, J., Lau, T.-K., Zhou, S., et al. (2018). Fused-Ring Electron Acceptor ITIC-Th: A Novel Stabilizer for Halide Perovskite Precursor Solution. Adv. Energ. Mater. 8, 1703399. doi:10.1002/aenm.201703399

Qiu, J., Qiu, Y., Yan, K., Zhong, M., Mu, C., Yan, H., et al. (2013). All-solid-state Hybrid Solar Cells Based on a New Organometal Halide Perovskite Sensitizer and One-Dimensional TiO2 Nanowire Arrays. Nanoscale 5, 3245-3248. doi:10.1039/c3nr00218g

Quarti, C., Mosconi, E., Ball, J. M., D’Innocenzo, V., Tao, C., Pathak, S., et al. (2016). Structural and Optical Properties of Methylammonium lead Iodide 
across the Tetragonal to Cubic Phase Transition: Implications for Perovskite Solar Cells. Energ. Environ. Sci. 9, 155-163. doi:10.1039/c5ee02925b

Ramirez, C., Yadavalli, S. K., Garces, H. F., Zhou, Y., and Padture, N. P. (2018). Thermo-mechanical Behavior of Organic-Inorganic Halide Perovskites for Solar Cells. Scripta Materialia 150, 36-41. doi:10.1016/j.scriptamat.2018.02.022

Rao, Z., Du, B., Huang, C., Shu, L., Lin, P., Fu, N., et al. (2019). Revisit of Amorphous Semiconductor InGaZnO4: A New Electron Transport Material for Perovskite Solar Cells. J. Alloys Compd. 789, 276-281. doi:10.1016/ j.jallcom.2019.02.311

Razera, R. A. Z., Jacobs, D. A., Fu, F., Fiala, P., Dussouillez, M., Sahli, F., et al. (2020). Instability of P-I-N Perovskite Solar Cells under Reverse Bias. J. Mater. Chem. A. 8, 242-250. doi:10.1039/c9ta12032g

Ren, N., Chen, B., Li, R., Wang, P., Mazumdar, S., Shi, B., et al. (2021). HumidityResistant Flexible Perovskite Solar Cells with over 20\% Efficiency. Sol. RRL 5, 2000795. doi:10.1002/solr.202000795

Ren, N., Chen, B., Shi, B., Wang, P., Xu, Q., Li, Y., et al. (2020). Quasi-Heteroface Perovskite Solar Cells. Small 16, 2002887. doi:10.1002/smll.202002887

Rogers, R. D., and Seddon, K. R. (2003). CHEMISTRY: Ionic Liquids--Solvents of the Future? Science 302, 792-793. doi:10.1126/science.1090313

Rolston, N., Printz, A. D., Hilt, F., Hovish, M. Q., Brüning, K., Tassone, C. J., et al. (2017). Improved Stability and Efficiency of Perovskite Solar Cells with Submicron Flexible Barrier Films Deposited in Air. J. Mater. Chem. A. 5, 22975-22983. doi:10.1039/c7ta09178h

Salado, M., Fernández, M. A., Holgado, J. P., Kazim, S., Nazeeruddin, M. K., Dyson, P. J., et al. (2017). Towards Extending Solar Cell Lifetimes: Addition of a Fluorous Cation to Triple Cation-Based Perovskite Films. Chemsuschem 10, 3846-3853. doi:10.1002/cssc.201700797

Salado, M., Ramos, F. J., Manzanares, V. M., Gao, P., Nazeeruddin, M. K., Dyson, P. J., et al. (2016). Extending the Lifetime of Perovskite Solar Cells Using a Perfluorinated Dopant. Chemsuschem 9, 2708-2714. doi:10.1002/ cssc. 201601030

Saliba, M., Matsui, T., Domanski, K., Seo, J.-Y., Ummadisingu, A., Zakeeruddin, S. M., et al. (2016). Incorporation of Rubidium Cations into Perovskite Solar Cells Improves Photovoltaic Performance. Science 354, 206-209. doi:10.1126/ science.aah5557

Saliba, M., Matsui, T., Seo, J.-Y., Domanski, K., Correa-Baena, J.-P., Nazeeruddin, M. K., et al. (2016). Cesium-containing Triple Cation Perovskite Solar Cells: Improved Stability, Reproducibility and High Efficiency. Energ. Environ. Sci. 9, 1989-1997. doi:10.1039/c5ee03874j

Sanehira, E. M., Tremolet De Villers, B. J., Schulz, P., Reese, M. O., Ferrere, S., Zhu, K., et al. (2016). Influence of Electrode Interfaces on the Stability of Perovskite Solar Cells: Reduced Degradation Using MoOx/Al for Hole Collection. ACS Energ. Lett. 1, 38-45. doi:10.1021/acsenergylett.6b00013

Schelhas, L. T., Li, Z., Christians, J. A., Goyal, A., Kairys, P., Harvey, S. P., et al. (2019). Insights into Operational Stability and Processing of Halide Perovskite Active Layers. Energ. Environ. Sci. 12, 1341-1348. doi:10.1039/ c8ee03051k

Schueller, E. C., Laurita, G., Fabini, D. H., Stoumpos, C. C., Kanatzidis, M. G., and Seshadri, R. (2018). Crystal Structure Evolution and Notable Thermal Expansion in Hybrid Perovskites Formamidinium Tin Iodide and Formamidinium Lead Bromide. Inorg. Chem. 57, 695-701. doi:10.1021/ acs.inorgchem.7b02576

Schulz, P., Cahen, D., and Kahn, A. (2019). Halide Perovskites: Is it All about the Interfaces? Chem. Rev. 119, 3349-3417. doi:10.1021/ acs.chemrev.8b00558

Seo, S., Jeong, S., Bae, C., Park, N.-G., and Shin, H. (2018). Perovskite Solar Cells with Inorganic Electron- and Hole-Transport Layers Exhibiting Long-Term $(\approx 500 \mathrm{H})$ Stability at $85{ }^{\circ} \mathrm{C}$ under Continuous 1 Sun Illumination in Ambient Air. Adv. Mater. 30, 1801010. doi:10.1002/adma.201801010

Shahiduzzaman, M., Yamamoto, K., Furumoto, Y., Kuwabara, T., Takahashi, K., and Taima, T. (2015). Ionic Liquid-Assisted Growth of Methylammonium lead Iodide Spherical Nanoparticles by a Simple Spin-Coating Method and Photovoltaic Properties of Perovskite Solar Cells. RSC Adv. 5, 77495-77500. doi:10.1039/c5ra08102e

Shahiduzzaman, M., Yamamoto, K., Furumoto, Y., Yonezawa, K., Hamada, K., Kuroda, K., et al. (2017). Viscosity Effect of Ionic Liquid-Assisted Controlled Growth of CH3NH3PbI3 Nanoparticle-Based Planar Perovskite Solar Cells. Org. Electron. 48, 147-153. doi:10.1016/j.orgel.2017.06.001
Shao, Y., Xiao, Z., Bi, C., Yuan, Y., and Huang, J. (2014). Nat. Commun. 5, 5784. doi:10.1038/ncomms6784

Shi, B., Duan, L., Zhao, Y., Luo, J., and Zhang, X. (2020a). Semitransparent Perovskite Solar Cells: From Materials and Devices to Applications. Adv. Mater. 32, 1806474. doi:10.1002/adma.201806474

Shi, B., Yao, X., Hou, F., Guo, S., Li, Y., Wei, C., et al. (2018). Unraveling the Passivation Process of PbI2 to Enhance the Efficiency of Planar Perovskite Solar Cells. J. Phys. Chem. C 122, 21269-21276. doi:10.1021/acs.jpcc.8b08075

Shi, L., Bucknall, M. P., Young, T. L., Zhang, M., Hu, L., Bing, J., et al. (2020b). Science 368, 1328. doi:10.1126/science.aba2412

Shi, L., Young, T. L., Kim, J., Sheng, Y., Wang, L., Chen, Y., et al. (2017). Accelerated Lifetime Testing of Organic-Inorganic Perovskite Solar Cells Encapsulated by Polyisobutylene. ACS Appl. Mater. Inter. 9, 25073-25081. doi:10.1021/ acsami.7b07625

Shin, S. S., Yeom, E. J., Yang, W. S., Hur, S., Kim, M. G., Im, J., et al. (2017). Colloidally Prepared La-Doped BaSnO 3 Electrodes for Efficient, Photostable Perovskite Solar Cells. Science 356, 167-171. doi:10.1126/science.aam6620

Singh, T., and Miyasaka, T. (2018). Stabilizing the Efficiency beyond $20 \%$ with a Mixed Cation Perovskite Solar Cell Fabricated in Ambient Air under Controlled Humidity. Adv. Energ. Mater. 8, 1700677. doi:10.1002/ aenm.201700677

Snaith, H. J., and Grätzel, M. (2006). Enhanced Charge Mobility in a Molecular Hole Transporter via Addition of Redox Inactive Ionic Dopant: Implication to Dye-Sensitized Solar Cells. Appl. Phys. Lett. 89, 262114. doi:10.1063/1.2424552

Soe, C. M. M., Stoumpos, C. C., Kepenekian, M., Traoré, B., Tsai, H., Nie, W., et al. (2017). New Type of 2D Perovskites with Alternating Cations in the Interlayer Space, $(\mathrm{C}(\mathrm{NH} 2) 3)(\mathrm{CH} 3 \mathrm{NH} 3) \mathrm{nPbnI} 3 \mathrm{n}+1$ : Structure, Properties, and Photovoltaic Performance. J. Am. Chem. Soc. 139, 16297-16309. doi:10.1021/jacs.7b09096

Son, D.-Y., Im, J.-H., Kim, H.-S., and Park, N.-G. (2014). 11\% Efficient Perovskite Solar Cell Based on ZnO Nanorods: An Effective Charge Collection System. J. Phys. Chem. C 118, 16567-16573. doi:10.1021/jp412407j

Song, S., Kang, G., Pyeon, L., Lim, C., Lee, G.-Y., Park, T., et al. (2017). Systematically Optimized Bilayered Electron Transport Layer for Highly Efficient Planar Perovskite Solar Cells $(\eta=21.1 \%)$. ACS Energ. Lett. 2, 2667-2673. doi:10.1021/acsenergylett.7b00888

Steirer, K. X., Schulz, P., Teeter, G., Stevanovic, V., Yang, M., Zhu, K., et al. (2016). Defect Tolerance in Methylammonium Lead Triiodide Perovskite. ACS Energ. Lett. 1, 360-366. doi:10.1021/acsenergylett.6b00196

Stoumpos, C. C., Malliakas, C. D., and Kanatzidis, M. G. (2013). Semiconducting Tin and Lead Iodide Perovskites with Organic Cations: Phase Transitions, High Mobilities, and Near-Infrared Photoluminescent Properties. Inorg. Chem. 52, 9019-9038. doi:10.1021/ic401215x

Stoumpos, C. C., Malliakas, C. D., Peters, J. A., Liu, Z., Sebastian, M., Im, J., et al. (2013). Crystal Growth of the Perovskite Semiconductor CsPbBr3: A New Material for High-Energy Radiation Detection. Cryst. Growth Des. 13, 2722-2727. doi:10.1021/cg400645t

Su, T.-S., Eickemeyer, F. T., Hope, M. A., Jahanbakhshi, F., Mladenović, M., Li, J., et al. (2020). Crown Ether Modulation Enables over 23\% Efficient Formamidinium-Based Perovskite Solar Cells. J. Am. Chem. Soc. 142, 19980-19991. doi:10.1021/jacs.0c08592

Subbiah, A. S., Halder, A., Ghosh, S., Mahuli, N., Hodes, G., and Sarkar, S. K. (2014). Inorganic Hole Conducting Layers for Perovskite-Based Solar Cells. J. Phys. Chem. Lett. 5, 1748-1753. doi:10.1021/jz500645n

Sun, W., Li, Y., Ye, S., Rao, H., Yan, W., Peng, H., et al. (2016). High-performance Inverted Planar Heterojunction Perovskite Solar Cells Based on a SolutionProcessed CuOxhole Transport Layer. Nanoscale 8, 10806-10813. doi:10.1039/ c6nr01927g

Sun, W., Ye, S., Rao, H., Li, Y., Liu, Z., Xiao, L., et al. (2016). Room-temperature and Solution-Processed Copper Iodide as the Hole Transport Layer for Inverted Planar Perovskite Solar Cells. Nanoscale 8, 15954-15960. doi:10.1039/ c6nr04288k

Sutton, R. J., Filip, M. R., Haghighirad, A. A., Sakai, N., Wenger, B., Giustino, F., et al. (2018). Cubic or Orthorhombic? Revealing the Crystal Structure of Metastable Black-phase CsPbI3 by Theory and Experiment. ACS Energ. Lett. 3, 1787-1794. doi:10.1021/acsenergylett.8b00672

Tamilselvan, M., and Bhattacharyya, A. J. (2018). Tetrahedrite (Cu12Sb4S13) Ternary Inorganic Hole Conductor for Ambient Processed Stable Perovskite 
Solar Cells. ACS Appl. Energ. Mater. 1, 4227-4234. doi:10.1021/ acsaem. 8 b00844

Tang, X., Brandl, M., May, B., Levchuk, I., Hou, Y., Richter, M., et al. (2016). Photoinduced Degradation of Methylammonium lead Triiodide Perovskite Semiconductors. J. Mater. Chem. A. 4, 15896-15903. doi:10.1039/c6ta06497c

Tian, C., Zhang, S., Mei, A., Rong, Y., Hu, Y., Du, K., et al. (2018). A Multifunctional Bis-Adduct Fullerene for Efficient Printable Mesoscopic Perovskite Solar Cells. ACS Appl. Mater. Inter. 10, 10835-10841. doi:10.1021/acsami.7b18945

Liu, T., Guo, J., Lu, D., Xu, Z., Fu, Q., Zheng, N., et al. (2021a). ACS Nano. doi:10.1021/acsnano.1021c02191

Tsai, H., Asadpour, R., Blancon, J.-C., Stoumpos, C. C., Durand, O., Strzalka, J. W., et al. (2018). Light-induced Lattice Expansion Leads to High-Efficiency Perovskite Solar Cells. Science 360, 67-70. doi:10.1126/science.aap8671

Tsai, H., Nie, W., Blancon, J.-C., Stoumpos, C. C., Asadpour, R., Harutyunyan, B., et al. (2016). High-efficiency Two-Dimensional Ruddlesden-Popper Perovskite Solar Cells. Nature 536, 312-316. doi:10.1038/nature18306

Tumen-Ulzii, G., Qin, C., Klotz, D., Leyden, M. R., Wang, P., Auffray, M., et al. (2020). Adv. Mater. 32, 1905035. doi:10.1002/adma.201905035

Tyagi, B., Lee, H. B., Kumar, N., and Kang, J.-W. (2020). Double-Halide Composition-Engineered SnO2-Triple Cation Perovskite Solar Cells Demonstrating Outstanding Performance and Stability. ACS Appl. Energ. Mater. 3, 8595-8605. doi:10.1021/acsaem.0c01214

Vargas, B., Torres-Cadena, R., Rodríguez-Hernández, J., Gembicky, M., Xie, H., Jiménez-Mier, J., et al. (2018). Optical, Electronic, and Magnetic Engineering of $\langle 111\rangle$ Layered Halide Perovskites. Chem. Mater. 30, 5315-5321. doi:10.1021/ acs.chemmater.8b02099

Walsh, K. K., Murphy, C., Russo, S., and Craciun, M. F. (2021). Front. Electron. 2. doi:10.3389/felec.2021.643687

Wang, C., Tang, Y., Hu, Y., Huang, L., Fu, J., Jin, J., et al. (2015). Graphene/ SrTiO3nanocomposites Used as an Effective Electron-Transporting Layer for High-Performance Perovskite Solar Cells. RSC Adv. 5, 52041-52047. doi:10.1039/c5ra09001f

Wang, F., Zhang, Y., Yang, M., Du, J., Xue, L., Yang, L., et al. (2019). Exploring Low-Temperature Processed A-WOx/SnO2 Hybrid Electron Transporting Layer for Perovskite Solar Cells with Efficiency $>20.5 \%$. Nano Energy 63, 103825. doi:10.1016/j.nanoen.2019.06.021

Wang, H., Liu, H., Li, W., Zhu, L., and Chen, H. (2020). Inorganic Perovskite Solar Cells Based on Carbon Electrodes. Nano Energy 77, 105160. doi:10.1016/ j.nanoen.2020.105160

Wang, J., Ye, X., Wang, Y., Wang, Z., Wong, W., and Li, C. (2019). Halide Perovskite Based on Hydrophobic Ionic Liquid for Stability Improving and its Application in High-Efficient Photovoltaic Cell. Electrochimica Acta 303, 133-139. doi:10.1016/j.electacta.2019.02.071

Wang, J., Zhang, J., Zhou, Y., Liu, H., Xue, Q., Li, X., et al. (2020b). Nat. Commun. 11, 177. doi:10.1038/s41467-019-13909-5

Wang, K., Olthof, S., Subhani, W. S., Jiang, X., Cao, Y., Duan, L., et al. (2020c). Novel Inorganic Electron Transport Layers for Planar Perovskite Solar Cells: Progress and Prospective. Nano Energy 68, 104289. doi:10.1016/j.nanoen.2019.104289

Wang, L., Zhou, H., Hu, J., Huang, B., Sun, M., Dong, B., et al. (2019b). A Eu3+Eu2+ Ion Redox Shuttle Imparts Operational Durability to Pb-I Perovskite Solar Cells. Science 363, 265-270. doi:10.1126/science.aau5701

Wang, P., Chen, B., Li, R., Wang, S., Ren, N., Li, Y., et al. (2021). Cobalt Chloride Hexahydrate Assisted in Reducing Energy Loss in Perovskite Solar Cells with Record Open-Circuit Voltage of 1.20 V. ACS Energ. Lett. 6, 2121-2128. doi:10.1021/acsenergylett.1c00443

Wang, P., Li, R., Chen, B., Hou, F., Zhang, J., Zhao, Y., et al. (2020). Gradient Energy Alignment Engineering for Planar Perovskite Solar Cells with Efficiency over 23\%. Adv. Mater. 32, 1905766. doi:10.1002/adma.201905766

Wang, P., Zhang, J., Zeng, Z., Chen, R., Huang, X., Wang, L., et al. (2016). Copper Iodide as a Potential Low-Cost Dopant for spiro-MeOTAD in Perovskite Solar Cells. J. Mater. Chem. C 4, 9003-9008. doi:10.1039/c6tc03077g

Wang, Q., Chen, B., Liu, Y., Deng, Y., Bai, Y., Dong, Q., et al. (2017). Scaling Behavior of Moisture-Induced Grain Degradation in Polycrystalline Hybrid Perovskite Thin Films. Energ. Environ. Sci. 10, 516-522. doi:10.1039/c6ee02941h

Wang, R., Xue, J., Meng, L., Lee, J.-W., Zhao, Z., Sun, P., et al. (2019). Caffeine Improves the Performance and Thermal Stability of Perovskite Solar Cells. Joule 3, 1464-1477. doi:10.1016/j.joule.2019.04.005
Wang, R., Xue, J., Wang, K.-L., Wang, Z.-K., Luo, Y., Fenning, D., et al. (2019). Constructive Molecular Configurations for Surface-Defect Passivation of Perovskite Photovoltaics. Science 366, 1509-1513. doi:10.1126/science.aay9698

Wang, S., Jiang, Y., Juarez-Perez, E. J., Ono, L. K., and Qi, Y. (2017b). Nat. Energ. 2, 16195. doi:10.1038/nenergy.2016.195

Wang, S., Li, X., Tong, T., Han, J., Zhang, Y., Zhu, J., et al. (2018). Sequential Processing: Spontaneous Improvements in Film Quality and Interfacial Engineering for Efficient Perovskite Solar Cells. Sol. RRL 2, 1800027. doi:10.1002/solr.201800027

Wang, S., Li, Z., Zhang, Y., Liu, X., Han, J., Li, X., et al. (2019). Water-Soluble Triazolium Ionic-Liquid-Induced Surface Self-Assembly to Enhance the Stability and Efficiency of Perovskite Solar Cells. Adv. Funct. Mater. 29, 1900417. doi:10.1002/adfm.201900417

Wang, S., Yang, B., Han, J., He, Z., Li, T., Cao, Q., et al. (2020). Polymeric RoomTemperature Molten Salt as a Multifunctional Additive toward Highly Efficient and Stable Inverted Planar Perovskite Solar Cells. Energ. Environ. Sci. 13, 5068-5079. doi:10.1039/d0ee02043e

Wang, X., Wu, J., Yang, Y., Liu, X., Guo, Q., Song, Z., et al. (2019). High Performance and Stable Perovskite Solar Cells Using Vanadic Oxide as a Dopant for spiro-OMeTAD. J. Mater. Chem. A. 7, 13256-13264. doi:10.1039/c9ta03351c

Wang, Y., Dar, M. I., Ono, L. K., Zhang, T., Kan, M., Li, Y., et al. (2019). Thermodynamically Stabilized $\beta$-CsPbI3-based Perovskite Solar Cells with Efficiencies $>18 \%$. Science 365, 591-595. doi:10.1126/science.aav8680

Wang, Y., Yue, Y., Yang, X., and Han, L. (2018). Toward Long-Term Stable and Highly Efficient Perovskite Solar Cells via Effective Charge Transporting Materials. Adv. Energ. Mater. 8, 1800249. doi:10.1002/aenm.201800249

Wang, Z., Lin, Q., Chmiel, F. P., Sakai, N., Herz, L. M., and Snaith, H. J. (2017). Nat. Energ. 2, 17135. doi:10.1038/nenergy.2017.135

Weber, O. J., Charles, B., and Weller, M. T. (2016). Phase Behaviour and Composition in the Formamidinium-Methylammonium Hybrid lead Iodide Perovskite Solid Solution. J. Mater. Chem. A. 4, 15375-15382. doi:10.1039/ c6ta06607k

Weerasinghe, H. C., Dkhissi, Y., Scully, A. D., Caruso, R. A., and Cheng, Y.-B. (2015). Encapsulation for Improving the Lifetime of Flexible Perovskite Solar Cells. Nano Energy 18, 118-125. doi:10.1016/j.nanoen.2015.10.006

Wei, J., Wang, Q., Huo, J., Gao, F., Gan, Z., Zhao, Q., et al. (2021). Mechanisms and Suppression of Photoinduced Degradation in Perovskite Solar Cells. Adv. Energ. Mater. 11, 2002326. doi:10.1002/aenm.202002326

Welton, T. (1999). Room-Temperature Ionic Liquids. Solvents for Synthesis and Catalysis. Chem. Rev. 99, 2071-2084. doi:10.1021/cr980032t

Wojciechowski, K., Stranks, S. D., Abate, A., Sadoughi, G., Sadhanala, A., Kopidakis, N., et al. (2014). Heterojunction Modification for Highly Efficient Organic-Inorganic Perovskite Solar Cells. Acs Nano 8, 12701-12709. doi:10.1021/nn505723h

Wu, G., Yang, T., Li, X., Ahmad, N., Zhang, X., Yue, S., et al. (2020a). Matter, 2021, 4, 582-599. doi:10.1016/j.matt.2020.11.011

Wu, W.-Q., Rudd, P. N., Ni, Z., Van Brackle, C. H., Wei, H., Wang, Q., et al. (2020b). Reducing Surface Halide Deficiency for Efficient and Stable IodideBased Perovskite Solar Cells. J. Am. Chem. Soc. 142, 3989-3996. doi:10.1021/ jacs.9b13418

Wu, W.-Q., Yang, Z., Rudd, P. N., Shao, Y., Dai, X., Wei, H., et al. (2019b). Sci. Adv. 5, eaav8925. doi:10.1126/sciadv.aav8925

Wu, X., Xie, L., Lin, K., Lu, J., Wang, K., Feng, W., et al. (2019). Efficient and Stable Carbon-Based Perovskite Solar Cells Enabled by the Inorganic Interface of CuSCN and Carbon Nanotubes. J. Mater. Chem. A. 7, 12236-12243. doi:10.1039/c9ta02014d

Wu, Y.-H., Shi, X.-Q., Ding, X.-H., Ren, Y.-K., Hayat, T., Alsaedi, A., et al. (2018). Incorporating 4-Tert-Butylpyridine in an Antisolvent: A Facile Approach to Obtain Highly Efficient and Stable Perovskite Solar Cells. ACS Appl. Mater. Inter. 10, 3602-3608. doi:10.1021/acsami.7b16912

Wu, Y., Xie, F., Chen, H., Yang, X., Su, H., Cai, M., et al. (2017). Thermally Stable MAPbI3Perovskite Solar Cells with Efficiency of $19.19 \%$ and Area over 1 Cm2achieved by Additive Engineering. Adv. Mater. 29, 1701073. doi:10.1002/ adma. 201701073

Wu, Z., Jiang, M., Liu, Z., Jamshaid, A., Ono, L. K., and Qi, Y. (2020). Highly Efficient Perovskite Solar Cells Enabled by Multiple Ligand Passivation. Adv Energ. Mater. 10, 1903696. doi:10.1002/aenm.201903696 
Wu, Z., Liu, Z., Hu, Z., Hawash, Z., Qiu, L., Jiang, Y., et al. (2019). Highly Efficient and Stable Perovskite Solar Cells via Modification of Energy Levels at the Perovskite/Carbon Electrode Interface. Adv. Mater. 31, 1804284. doi:10.1002/ adma.201804284

Xia, R., Fei, Z., Drigo, N., Bobbink, F. D., Huang, Z., Jasiūnas, R., et al. (2019). Retarding Thermal Degradation in Hybrid Perovskites by Ionic Liquid Additives. Adv. Funct. Mater. 29, 1902021. doi:10.1002/adfm.201902021

Xiao, K., Han, Q., Gao, Y., Gu, S., Luo, X., Lin, R., et al. (2021). Simultaneously Enhanced Moisture Tolerance and Defect Passivation of Perovskite Solar Cells with Cross-Linked Grain Encapsulation. J. Energ. Chem. 56, 455-462. doi:10.1016/j.jechem.2020.08.020

Xie, F., Chen, C.-C., Wu, Y., Li, X., Cai, M., Liu, X., et al. (2017). Vertical Recrystallization for Highly Efficient and Stable Formamidinium-Based Inverted-Structure Perovskite Solar Cells. Energ. Environ. Sci. 10, 1942-1949. doi:10.1039/c7ee01675a

Xin, C., Zhang, J., Zhou, X., Ma, L., Hou, F., Shi, B., et al. (2020). Defects Healing in Two-step Deposited Perovskite Solar Cells via Formamidinium Iodide Compensation. ACS Appl. Energ. Mater. 3, 3318-3327. doi:10.1021/ acsaem.9b02336

Xu, J., Buin, A., Ip, A. H., Li, W., Voznyy, O., Comin, R., et al. (2015). Nat. Commun. 6, 7081.

Xu, P., Chen, S., Xiang, H.-J., Gong, X.-G., and Wei, S.-H. (2014). Influence of Defects and Synthesis Conditions on the Photovoltaic Performance of Perovskite Semiconductor CsSnI3. Chem. Mater. 26, 6068-6072. doi:10.1021/cm503122j

Xu, Z., Lu, D., Liu, F., Lai, H., Wan, X., Zhang, X., et al. (2020). Phase Distribution and Carrier Dynamics in Multiple-Ring Aromatic Spacer-Based TwoDimensional Ruddlesden-Popper Perovskite Solar Cells. Acs Nano 14, 4871-4881. doi:10.1021/acsnano.0c00875

Yang, D., Yang, R., Wang, K., Wu, C., Zhu, X., Feng, J., et al. (2018a). Nat. Commun. 9, 3239. doi:10.1038/s41467-018-05760-x

Yang, D., Zhou, X., Yang, R., Yang, Z., Yu, W., Wang, X., et al. (2016). Surface Optimization to Eliminate Hysteresis for Record Efficiency Planar Perovskite Solar Cells. Energ. Environ. Sci. 9, 3071-3078.

Yang, G., Qin, P., Fang, G., and Li, G. (2018). A Lewis Base-Assisted Passivation Strategy towards Highly Efficient and Stable Perovskite Solar Cells. Sol. RRL 2, 1800055. doi:10.1002/solr.201800055

Yang, J.-a., Xiao, A., Xie, L., Liao, K., Deng, X., Li, C., et al. (2020). Precise Control of PbI2 Excess into Grain Boundary for Efficacious Charge Extraction in OffStoichiometric Perovskite Solar Cells. Electrochimica Acta 338, 135697. doi:10.1016/j.electacta.2020.135697

Yang, S., Chen, S., Mosconi, E., Fang, Y., Xiao, X., Wang, C., et al. (2019). Stabilizing Halide Perovskite Surfaces for Solar Cell Operation with WideBandgap lead Oxysalts. Science 365, 473-478. doi:10.1126/science.aax3294

Yang, Z., Dou, J., Kou, S., Dang, J., Ji, Y., Yang, G., et al. (2020). Multifunctional Phosphorus-Containing Lewis Acid and Base Passivation Enabling Efficient and Moisture-Stable Perovskite Solar Cells. Adv. Funct. Mater. 30, 1910710. doi:10.1002/adfm.201910710

Yang, Z., Wang, H., Huang, M., Liu, Y., Lv, Q., Lv, F., et al. (2021). Hot Debate on Perovskite Solar Cells: Stability, Toxicity, High-Efficiency and Low Cost. J. Energ. Chem. 53, 407-411. doi:10.1016/j.jechem.2020.04.028

Ye, Q., Ma, F., Zhao, Y., Yu, S., Chu, Z., Gao, P., et al. (2020). Stabilizing $\gamma$-CsPbI 3 Perovskite via Phenylethylammonium for Efficient Solar Cells with Open-Circuit Voltage over 1.3 V. Small 16, 2005246. doi:10.1002/ smll.202005246

Yella, A., Heiniger, L.-P., Gao, P., Nazeeruddin, M. K., and Grätzel, M. (2014). Nanocrystalline Rutile Electron Extraction Layer Enables Low-Temperature Solution Processed Perovskite Photovoltaics with 13.7\% Efficiency. Nano Lett. 14, 2591-2596. doi:10.1021/nl500399m

Yin, M., Xie, F., Chen, H., Yang, X., Ye, F., Bi, E., et al. (2016). Annealing-free Perovskite Films by Instant Crystallization for Efficient Solar Cells. J. Mater. Chem. A. 4, 8548-8553. doi:10.1039/c6ta02490d

Yin, W.-J., Shi, T., and Yan, Y. (2014). Appl. Phys. Lett. 104, 063903. doi:10.1063/ 1.4864778

Yin, X., Chen, P., Que, M., Xing, Y., Que, W., Niu, C., et al. (2016b). Highly Efficient Flexible Perovskite Solar Cells Using Solution-Derived NiOx Hole Contacts. Acs Nano 10, 3630-3636. doi:10.1021/acsnano.5b08135
You, J., Meng, L., Song, T.-B., Guo, T.-F., Yang, Y., Chang, W.-H., et al. (2016). Improved Air Stability of Perovskite Solar Cells via Solution-Processed Metal Oxide Transport Layers. Nat. Nanotech 11, 75-81. doi:10.1038/nnano.2015.230

Yuan, M., Quan, L. N., Comin, R., Walters, G., Sabatini, R., Voznyy, O., et al. (2016). Perovskite Energy Funnels for Efficient Light-Emitting Diodes. Nat. Nanotech 11, 872-877. doi:10.1038/nnano.2016.110

Zhang, F., Bi, D., Pellet, N., Xiao, C., Li, Z., Berry, J. J., et al. (2018). Suppressing Defects through the Synergistic Effect of a Lewis Base and a Lewis Acid for Highly Efficient and Stable Perovskite Solar Cells. Energ. Environ. Sci. 11, 3480-3490. doi:10.1039/c8ee02252f

Zhang, F., Lu, H., Tong, J., Berry, J. J., Beard, M. C., and Zhu, K. (2020). Advances in Two-Dimensional Organic-Inorganic Hybrid Perovskites. Energ. Environ. Sci. 13, 1154-1186. doi:10.1039/c9ee03757h

Zhang, F., Shi, W., Luo, J., Pellet, N., Yi, C., Li, X., et al. (2017). Isomer-Pure BisPCBM-Assisted Crystal Engineering of Perovskite Solar Cells Showing Excellent Efficiency and Stability. Adv. Mater. 29, 1606806. doi:10.1002/ adma.201606806

Zhang, H., Wang, H., Zhu, H., Chueh, C. C., Chen, W., Yang, S., et al. (2018a). LowTemperature Solution-Processed CuCrO 2 Hole-Transporting Layer for Efficient and Photostable Perovskite Solar Cells. Adv. Energ. Mater. 8, 1702762. doi:10.1002/aenm.201702762

Zhang, S., Chen, W., Wu, S., Chen, R., Liu, Z., Huang, Y., et al. (2019b). Hybrid Inorganic Electron-Transporting Layer Coupled with a Halogen-Resistant Electrode in CsPbI2Br-Based Perovskite Solar Cells to Achieve Robust Long-Term Stability. ACS Appl. Mater. Inter. 11, 43303-43311. doi:10.1021/ acsami.9b17464

Zhang, Y., Liu, X., Li, P., Duan, Y., Hu, X., Li, F., et al. (2019). Dopaminecrosslinked TiO2/perovskite Layer for Efficient and Photostable Perovskite Solar Cells under Full Spectral Continuous Illumination. Nano Energy 56, 733-740. doi:10.1016/j.nanoen.2018.11.068

Zhang, Y., Wang, P., Tang, M.-C., Barrit, D., Ke, W., Liu, J., et al. (2019). Dynamical Transformation of Two-Dimensional Perovskites with Alternating Cations in the Interlayer Space for High-Performance Photovoltaics. J. Am. Chem. Soc. 141, 2684-2694. doi:10.1021/jacs.8b13104

Zhao, K., Li, Y., Cheng, H., Hu, K., and Wang, Z.-S. (2020). Efficient Inverted Perovskite Solar Cells with $\mathrm{CuSeCN}$ as the Hole Transport Material. J. Power Sourc. 472, 228505. doi:10.1016/j.jpowsour.2020.228505

Zhao, L., Kerner, R. A., Xiao, Z., Lin, Y. L., Lee, K. M., Schwartz, J., et al. (2016). Redox Chemistry Dominates the Degradation and Decomposition of Metal Halide Perovskite Optoelectronic Devices. ACS Energ. Lett. 1, 595-602. doi:10.1021/acsenergylett.6b00320

Zhao, W., Li, H., Li, D., Liu, Z., Wang, D., and Liu, S. (2019). Comprehensive Investigation of Sputtered and Spin-Coated Zinc Oxide Electron Transport Layers for Highly Efficient and Stable Planar Perovskite Solar Cells. J. Power Sourc. 427, 223-230. doi:10.1016/j.jpowsour.2019.04.088

Zhao, Y., Nardes, A. M., and Zhu, K. (2014). Effective Hole Extraction Using MoOx-Al Contact in Perovskite CH3NH3PbI3 Solar Cells. Appl. Phys. Lett. 104, 213906. doi:10.1063/1.4880899

Zheng, D., Peng, R., Wang, G., Logsdon, J. L., Wang, B., Hu, X., et al. (2019). Simultaneous Bottom-Up Interfacial and Bulk Defect Passivation in Highly Efficient Planar Perovskite Solar Cells Using Nonconjugated SmallMolecule Electrolytes. Adv. Mater. 31, 1903239. doi:10.1002/ adma.201903239

Zheng, X., Troughton, J., Gasparini, N., Lin, Y., Wei, M., Hou, Y., et al. (2019). Quantum Dots Supply Bulk- and Surface-Passivation Agents for Efficient and Stable Perovskite Solar Cells. Joule 3, 1963-1976. doi:10.1016/ j.joule.2019.05.005

Zheng, X., Wei, Z., Chen, H., Zhang, Q., He, H., Xiao, S., et al. (2016). Designing Nanobowl Arrays of Mesoporous TiO2as an Alternative Electron Transporting Layer for Carbon Cathode-Based Perovskite Solar Cells. Nanoscale 8, 6393-6402. doi:10.1039/c5nr06715d

Zhou, N., Shen, Y., Li, L., Tan, S., Liu, N., Zheng, G., et al. (2018). Exploration of Crystallization Kinetics in Quasi Two-Dimensional Perovskite and High Performance Solar Cells. J. Am. Chem. Soc. 140, 459-465. doi:10.1021/ jacs.7b11157

Zhou, Q., Duan, J., Yang, X., Duan, Y., and Tang, Q. (2020). Interfacial Strain Release from the WS 2/CsPbBr 3 van der Waals Heterostructure for $1.7 \mathrm{~V}$ 
Voltage All-Inorganic Perovskite Solar Cells. Angew. Chem. Int. Ed. 59, 21997-22001. doi:10.1002/anie.202010252

Zhou, T., Lai, H., Liu, T., Lu, D., Wan, X., Zhang, X., et al. (2019). Highly Efficient and Stable Solar Cells Based on Crystalline Oriented 2D/3D Hybrid Perovskite. Adv. Mater. 31, 1901242. doi:10.1002/ adma.201901242

Zhou, W., Li, D., Xiao, Z., Wen, Z., Zhang, M., Hu, W., et al. (2019). Zwitterion Coordination Induced Highly Orientational Order of $\mathrm{CH} 3 \mathrm{NH} 3 \mathrm{PbI} 3$ Perovskite Film Delivers a High Open Circuit Voltage Exceeding 1.2 V. Adv. Funct. Mater. 29, 1901026. doi:10.1002/adfm.201901026

Zhou, X., Wang, Y., Li, C., and Wu, T. (2019). Doping Amino-Functionalized Ionic Liquid in Perovskite crystal for Enhancing Performances of Hole-Conductor Free Solar Cells with Carbon Electrode. Chem. Eng. J. 372, 46-52. doi:10.1016/ j.cej.2019.04.099

Zhou, Z., Qiang, Z., Sakamaki, T., Takei, I., Shang, R., and Nakamura, E. (2019). Organic/Inorganic Hybrid P-type Semiconductor Doping Affords Hole Transporting Layer Free Thin-Film Perovskite Solar Cells with High Stability. ACS Appl. Mater. Inter. 11, 22603-22611. doi:10.1021/ acsami.9b06513

Zhu, H., Zhang, F., Xiao, Y., Wang, S., and Li, X. (2018). Suppressing Defects through Thiadiazole Derivatives that Modulate CH3NH3PbI3 crystal Growth for Highly Stable Perovskite Solar Cells under Dark Conditions. J. Mater. Chem. A. 6, 4971-4980. doi:10.1039/c8ta00769a

Zhu, S., Yao, X., Ren, Q., Zheng, C., Li, S., Tong, Y., et al. (2018). Transparent Electrode for Monolithic Perovskite/silicon-Heterojunction Two-Terminal Tandem Solar Cells. Nano Energy 45, 280-286. doi:10.1016/ j.nanoen.2017.12.043
Zhu, Z., Bai, Y., Liu, X., Chueh, C.-C., Yang, S., and Jen, A. K.-Y. (2016) Enhanced Efficiency and Stability of Inverted Perovskite Solar Cells Using Highly Crystalline SnO2Nanocrystals as the Robust ElectronTransporting Layer. Adv. Mater. 28, 6478-6484. doi:10.1002/ adma.201600619

Zuo, L., Gu, Z., Ye, T., Fu, W., Wu, G., Li, H., et al. (2015). Enhanced Photovoltaic Performance of $\mathrm{CH} 3 \mathrm{NH} 3 \mathrm{PbI} 3$ Perovskite Solar Cells through Interfacial Engineering Using Self-Assembling Monolayer. J. Am. Chem. Soc. 137, 2674-2679. doi:10.1021/ja512518r

Conflict of Interest: The authors declare that the research was conducted in the absence of any commercial or financial relationships that could be construed as a potential conflict of interest.

Publisher's Note: All claims expressed in this article are solely those of the authors and do not necessarily represent those of their affiliated organizations, or those of the publisher, the editors and the reviewers. Any product that may be evaluated in this article, or claim that may be made by its manufacturer, is not guaranteed or endorsed by the publisher.

Copyright (c) 2021 Mazumdar, Zhao and Zhang. This is an open-access article distributed under the terms of the Creative Commons Attribution License (CC BY). The use, distribution or reproduction in other forums is permitted, provided the original author(s) and the copyright owner(s) are credited and that the original publication in this journal is cited, in accordance with accepted academic practice. No use, distribution or reproduction is permitted which does not comply with these terms. 